Annual Report

\title{
DEPOSITIONAL SETTING, STRUCTURAL STYLE, AND SANDSTONE DISTRIBUTION IN THREE GEOPRESSURED GEOTHERMAL AREAS, TEXAS GULF COAST
}

C. D. Winker, R. A. Morton, T. E. Ewing, and D. D. Garcia

\author{
Assisted by \\ J. H. Han, J. L. Lawton, R. J. Padilla y Sanchez, J. J. Palmer, \\ C. L. Ping, and R. D. Rasco
}

\author{
Prepared for the \\ U.S. Department of Energy \\ Division of Geothermal Energy \\ Under Contract No. DE-AC08-79ET27111 \\ Bureau of Economic Geology \\ W. L. Fisher, Director \\ The University of Texas at Austin \\ University Station, Box X \\ Austin, Texas 78712
}

October 1981 


\section{DISCLAIMER}

This report was prepared as an account of work sponsored by an agency of the United States Government. Neither the United States Government nor any agency Thereof, nor any of their employees, makes any warranty, express or implied, or assumes any legal liability or responsibility for the accuracy, completeness, or usefulness of any information, apparatus, product, or process disclosed, or represents that its use would not infringe privately owned rights. Reference herein to any specific commercial product, process, or service by trade name, trademark, manufacturer, or otherwise does not necessarily constitute or imply its endorsement, recommendation, or favoring by the United States Government or any agency thereof. The views and opinions of authors expressed herein do not necessarily state or reflect those of the United States Government or any agency thereof. 


\section{DISCLAIMER}

Portions of this document may be illegible in electronic image products. Images are produced from the best available original document. 

TABLE OF CONTENTS

ABSTRACT

INTRODUCTION.

PLEASANT BAYOU AREA . . . . . . . . . . . . . . 5

Stratigraphic and Paleogeographic Setting . . . . . . . . . 5

Operational Stratigraphy . . . . . . . . . . . 8

Structural Setting . . . . . . . . . . . . . . . 12

Local Structure . . . . . . . . . . . . . . 12

Structural Style . . . . . . . . . . . . . . 13

Structural Evolution . . . . . . . . . . . . . . 18

Sandstone Facies . . . . . . . . . . . . . . . . 21

Pressure Distribution . . . . . . . . . . . . . . . 30

Seismic Studies • • • • • • • • • • • • : • 35

Mobil СB-78-1 • . . • . . . . . . . . . 38

Teledyne 6-F . . . . . . . . . . . . . . . . . 41

Western W-4 . . . . . . . . . . . . . 41

Western W-3. . . . . . . . . . . . 43

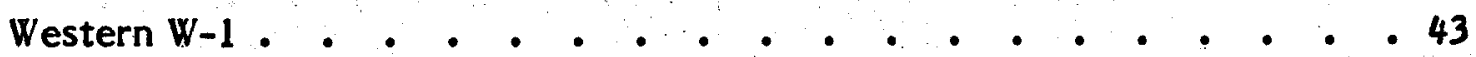

Western W-5 . . . . . . . . . . . . . . 43

Velocity Distribution . . . . . . . . . . . . . 47

Interval Velocities . . . . . . . . . . . . 48

Time-Depth Conversion. . . . . . . . . . . 50

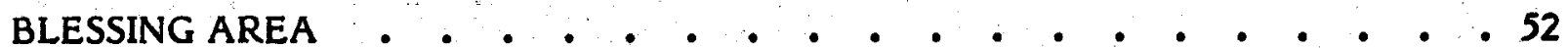

Stratigraphic and Paleogeographic Setting . . . . . . . . 52 
Operational Stratigraphy

Structural Setting . . . . . . . . . . . . . . 55

Local Structure . . . . . . . . . . . . . . 55

Structural Style . . . . . . . . . . . . . 55

Structural Evolution . • • • • • • • • • • • • •

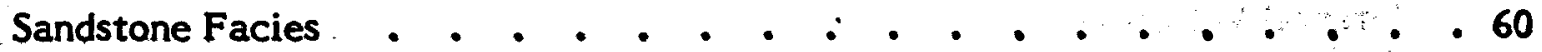

Pressure Distribution . . . . . . . . . . . . . 60

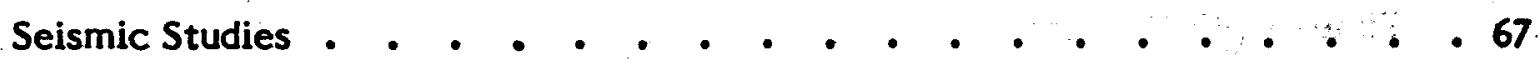

Amoco BCH-27, BCH-29, BCH-30 • . . . . . . . . 69

Coastal States CS-2; Mobil F . . . . . . . . . . . . . 69

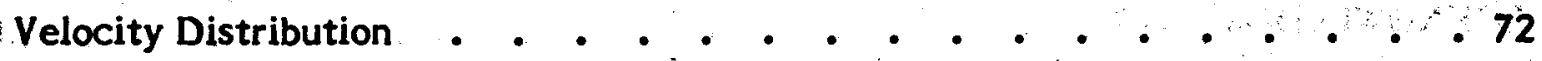

Interval Velocities . . . . . . . . . . . . . . 72

Time-Depth Conversion . . . . . . . . . . . . 72

CUERO AREA . . . . . . . . . . . . . . . . . . 75

Stratigraphic and Paleogeographic Setting . . . . . . . . 75

Operational Stratigraphy . • . • . • . . . . . .

Structural Setting . • . . . . . . . . . . . . 83

Local Structure . . . . . . . . . . . . . . 83

Structural Style . . . . • . . . . • . . . 84

Structural Evolution _. . • . • . . . . . . . . 88

Sandstone Facies

Pressure Distribution . . . . . . . . . • • • . 94

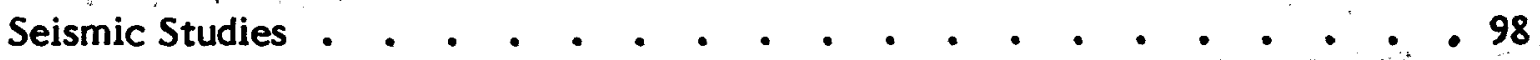

Proprietary Data . . . . . . . . . . . . . . 104

New Data. . . . . . . . . . . . . . . 104

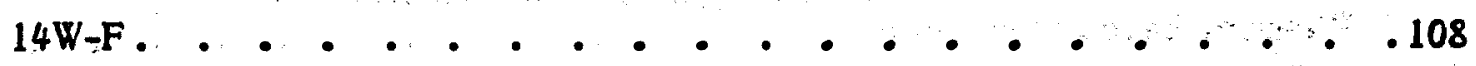




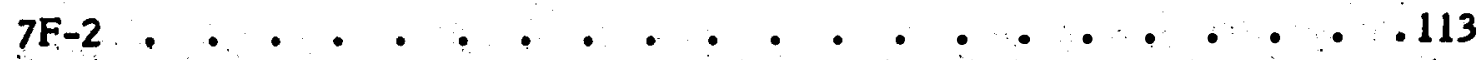

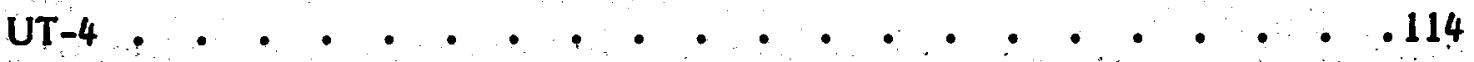

UT-2 and UT-3 . . . . . . . . . . . . . . 117

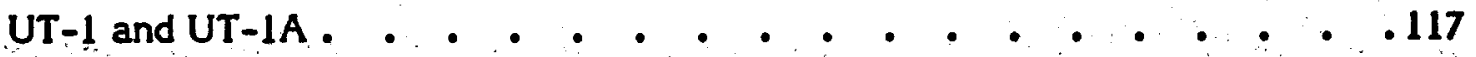

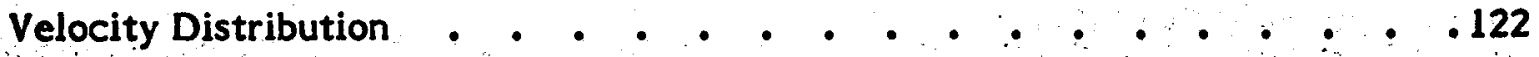

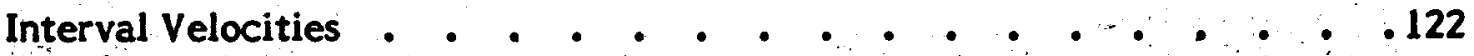

Stacking and rms Velocities . . . . . . . . . . 122

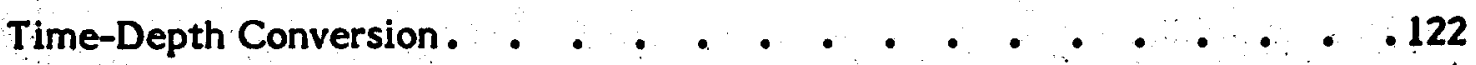

"Wipe-out"Zones • • • • • . • • • • • • • • • 125

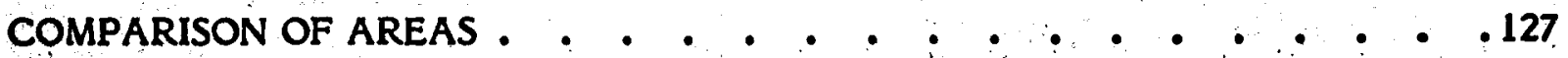

ACKNOWLEDGMENTS * . . . . . . . . . . . . 128

REFERENCES . . . . . . . . . . . . . . . 130

Figures

1. Location of Pleasant Bayou, Blessing, and Cuero study areas in relation to regional shelf-margin trends, northwestern Gulf of

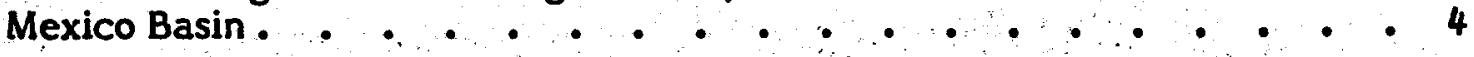

2. Location of Pleasant Bayou and Blessing study areas in relation to

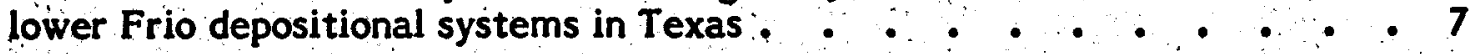

3. Data base and locations of sections in Pleasant Bayou area,

Brazoria County . . . . . . . . . . . . 9

4. Structural dip section through Chocolate Bayou field, illustrating log character of stratigraphic units in Pleasant Bayou area $\quad . \quad . \quad .10$

5. Dip sections of four geopressured geothermal study areas _ . . . 14

6. Structure map of TA marker . . . . . . . . . . . 15

7. Structure map of T2 marker . . . . . . . . . . 16

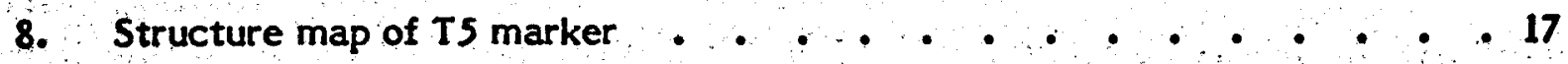

9. Sequential isopach maps illustrating structural evolution of

Pleasant Bayou study area . . . . . . . . . 
10. Seismic sections of modern continental slope, illustrating modern structural features analogous to Frio structures in Texas . . . . . 20

11. Stratigraphic dip section of lower Frio . . . . . . . . 23

12. Stratigraphic strike section of lower Frio. . . . . . . . . 24

13. Log-pattern map of ' $A$ ' sand, lower Frio, with gas-well completions 25

14. Log-pattern map of ' $C$ ' sand (geothermal reservoir sand), lower Frio, with gas-well completions . . . . . . . . . . . . . 26

15. Log-pattern map of ' $D$ ' sand, lower Frio, with gas-well completions _ . 27

16. Distribution of optimum sandstone facies as inferred from electric-log patterns in three geothermal study areas . . . . . . 28

17. Distribution of pressure gradients across Chocolate Bayou field . . . 31

18. Static bottom-hole pressures versus depth for a number of wells, Chocolate Bayou field . . . . . . . . . . . . 32

19. Distribution of pressure gradients across Chocolate Bayou field $\quad \cdot \quad \cdot 33$

20. Mud-weight data for wells in cross section from figure $19 . . \quad . . .34$

21. Base map of seismic data . . . . . . . . . . . . 36

22. Mobil line $\mathrm{CB}-78-1$ after reprocessing and migration $\quad . \quad+\quad . \quad 39$

23. Teledyne line 6F, after reprocessing and migration . . . . 40

24. Interpreted version of line $W-4$, after reprocessing and migration

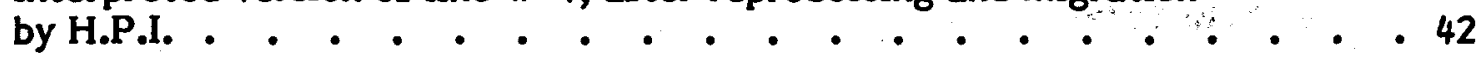

25. Line $W-3$, after reprocessing and migration by H.P.I..... .44

26. Western line $W-1$, as delivered. . . . . . . . 45

27. Western line W-5, as delivered. . • . . . . . . . 46

28. Interval velocities as determined from velocity surveys in five wells in Brazoria County . . . . . . . . . . . . . . 49

29. Range of time-depth curves obtained from six velocity surveys in Brazoria County. . . . . . . . . . . . . 51

30. Base map showing locations of available deep well control, seismic sections, and velocity surveys in the Blessing study area... .54

31. Structure map of Bl correlation marker - • • • • 


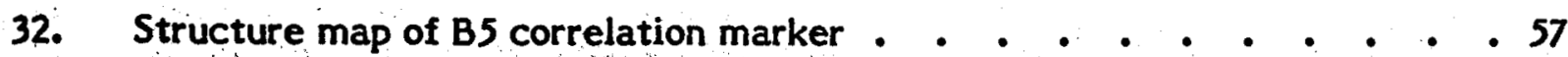

33. Sequential isopach maps illustrating structural evolution of the

Blessing study area . . . . . . . . . . . . . . . 59

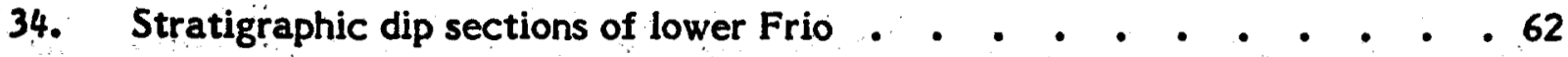

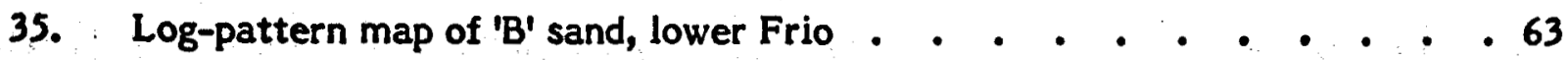

36. Log-pattern map of 'C' sand, lower Frio . . . . . . . . . . . . 64

37. Static bottom-hole pressures versus depth for Matagorda County wells . . 65

38. Shale resistivity versus depth, Blessing area - . . . . . . . . . 66

39. Seismic dip section $\mathrm{BCH}-27, \mathrm{BCH}-29$ and $\mathrm{BCH}-30$. . . . . . . 70

40. Seismic dip section CS-2 and F. . . . . . . . . . . . . . . 71

41. Interval velocities as determined from velocity surveys from six

wells in the Blessing area.....++ .473

42. Range of time-depth curves obtained from six velocity surveys in

the Blessing area. . . . . . . . . . . . . . . 74

43. Location of Cuero study area in relation to Rockdale Delta system and barrier/strandplain facies . . . . . . . . . . . . . 77

44. Location of Cuero study area in relation to net-sandstone

distribution and upper limit of geopressure (based on mud weights)

in the lower Wilcox . . . . . . . . . . . . . . . . 78

45. Location of Cuero study area in relation to regional Wilcox growth

faults in Texas .......... . . . . . . . . . 79

46. Data base and locations of well-log sections, Cuero study area . . . . 81

47. Structural dip section of Cuero study area, illustrating $\log$

character of stratigraphic units . . . . . . . . . . 82

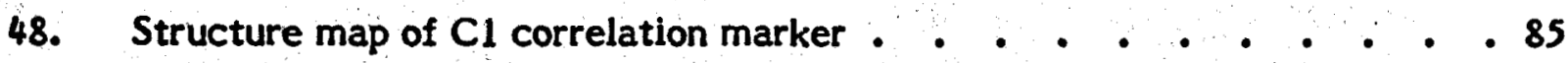

49. Structure map of TW correlation marker _ _ _ . _ _ . . . . 86

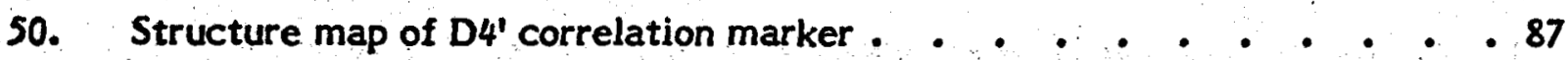

51. Sequential isopach maps illustrating structural evolution of 89

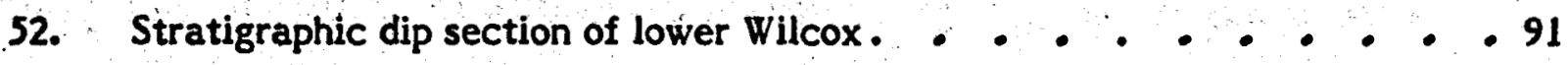

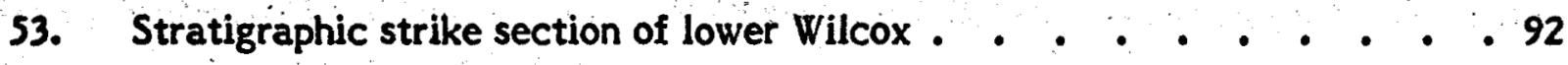


54. Lower Wilcox paleogeography of Cuero study area $\ldots \ldots \ldots 3$

55. Log patterns of three lower Wilcox sandstones in the South Cook fault block . . . . . . . . . • . . . . . 95

56. Electric log with permeability data and environmental

interpretations for lower Wilcox section, Atlantic \#1 Schorre . . . . . 96

57. Plot of bottom-hole shut-in pressures versus depth from gas wells

in De Witt County . . . . . . . . . . . . 97

58. Shale-resistivity plot for Atlantic 非 1 Schorre used to estimate pressure gradients . • . . • • • • • • . . . 99

59. Shale-resistivity plot for Gulf \#1 Mueller well _ . . . . . . . 100

60. Parameter plots for wells in section in figure 47, illustrating top of geopressure as picked from shale resistivities . . . . . . . 101

61. Base map of seismic data in Cuero area . . . . . . . 103

62. Interpreted version of migrated line $14 \mathrm{~W}-\mathrm{F}+\ldots .+. \quad 105$

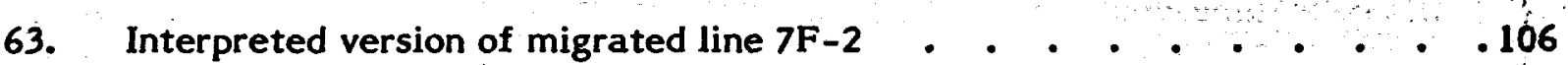

64. Originally proposed layout of shotpoints with staggered offsets to provide cross-dip control . . . . . . . . . . . . . 107

65. Map of shotholes, geophone stations, and shot-receiver midpoints for a segment of line UT-4... . . . . . . . . . . . . . 109

66. Structural dip sections constructed before acquisition of UT LW - 3 or reprocessing of proprietary lines . . . . . . . . 110

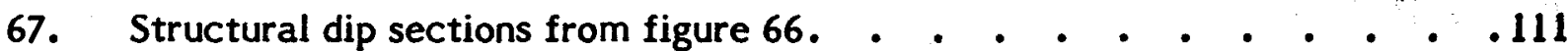

68. Wavefront and raypath diagram, Atlantic 非 1 Hartman well _ . . . 112

69. Migrated line UT-4 with interpretations . . . . . . . . . . . 115

70. Line UT -4 restacked with velocities approximately 1.4 times

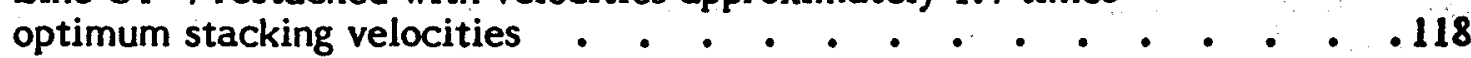

71. Migrated line UT-2, with interpretations . . . . . . . . . . . 119

72. Migrated line UT-3, with interpretations . . . . . . . . . . 120

73. Composite strike section UT-1 and UT-1A - . - . - .

74. Interval velocities based on velocity surveys from five wells $\ldots \quad \ldots \ldots$

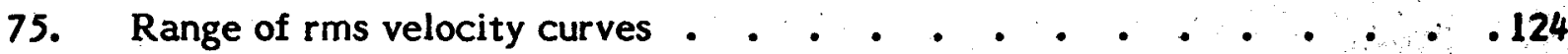

76. Time-depth conversions for the Cuero area . . . . . . . . . 126 
1. Characteristics of operational stratigraphic units in the Pleasant

Bayou area . • • • • • • • • • • • • 6

2. Approximate stratigraphic position of log- and seismic-correlation

markers and functional stratigraphic units in four geothermal areas . . . 11

3. Electric-log facies in the Anomalina bilateralis zone, lower Frio, Pleasant Bayou area. . • • • • • . . . . . . . . 22

4. Reservoir parameters for three areas in the Texas Gulf Coast . . . . . 29

5. Seismic lines acquired for evaluation of the Pleasant Bayou area . . . 37

6. Characteristics of operational stratigraphic units in the Blessing area . 53

7. Electric-log facies in the Anomalina bilateralis zone, lower Frio, Blessing area. . . . . . . . . . . . . . . .61

8. Seismic lines acquired for evaluation of the Blessing area . . . . . 68

9. Characteristics of operational stratigraphic units in the Cuero area . . . 76

10. Electric-log facies in the lower Wilcox used for paleogeographic mapping in the Cuero area . . . . . . . . . . . 90

11. Seismic lines acquired for evaluation of the Cuero area . . . . . 102 
ABSTRACT

Three areas in the Texas Gulf Coast region with different depositional settings, structural styles, and sandstone distribution were studied with well log and seismic data to evaluate some of the controls on subsurface conditions in geopressured aquifers. Major differences in these subsurface properties make some areas more favorable than others for exploration and development of unconventional gas.

Structural and stratigraphic interpretations were made primarily on the basis of well log correlations. Seismic data confirm the log interpretations but also are useful in structure mapping at depths below well control. Selected seismic sections were reprocessed to improve signal-to-noise ratio, enhance deep reflectors, and suppress multiples; however, not all of the lines benefited from reprocessing. Those lines that benefited the least typically had poor signal-to-noise ratio, problems with statics, multiples, or oblique dip orientation that caused further deterioration of the seismic image. Migration proved to be beneficial for fault interpretations. For the most part, velocity variations in these areas are stratigraphically controlled. As a result, the top of geopressure cannot be mapped on the basis of velocity inversion alone.

The Pleasant Bayou area is characterized by a complex structure resulting from salt tectonics superimposed on a greatly expanded and growth-faulted section of the lower Frio Formation. The thickest and most laterally continuous geopressured sandstones were deposited in delta-front or distributary-mouth bar and channel environments of a delta system. The fault block area is large $\left(\approx 25 \mathrm{mi}^{2}\right)$ and nearly equidimensional in both strike and dip directions. Sandstone distribution within the fault block varies from patchy to continuous. Some of these sandstones exhibit high permeabilities and appear to be excellent aquifers. 
In the Blessing area, shale tectonics combined with regional growth faulting to produce sinuous fault patterns and fault blocks of varying size in the lower Frio Formation. The primary fault block, nearly $36 \mathrm{mi}^{2}$ in extent, is elongate parallel to strike and is about twice as long as it is wide. Optimum sandstone distribution roughly parallels depositional and structural strike and occurs along the central axis of the fault block. These strike-oriented sandstone bodies were probably deposited in barrier-strandplain environments.

In contrast to the Pleasant Bayou and Blessing areas, the structural evolution of the Cuero area did not involve salt mobilization or shale diapirism. Instead, relatively straight and closely spaced growth faults having minimal displacement and minor rollover are typical in the lower Wilcox Group. The resulting fault blocks are narrow and highly elongate. The fault block of interest covers nearly $10 \mathrm{mi}^{2}$ and is about 10 times longer than it is wide. Optimum sandstone distribution in the primary fault block is strongly dip aligned. These relatively narrow sandstone bodies exhibit blocky SP patterns and most likely are distributary channel fills. Although the channels have good reservoir properties, they have substantially smaller areas and volumes than Frio reservoirs.

Features that are similar to the three areas include (1) progradation and deposition near the contemporaneous shelf edge, and (2) structural and stratigraphic factors that control the distribution of geopressure. In these examples; geopressured sandstones are isolated on the updip side of a fault block by downfaulting against shelf-slope shales, and on the downdip side by upfaulting against transgressive marine shales. Moreover, they are isolated above and below by thick sequences of marine shale or interbedded sandstone and shale. 


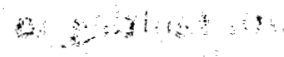

\section{INTRODUCTION}

Structural and stratigraphic interpretation of geopressured geothermal areas on a site-specific scale is necessary to predict reservoir size and the potential volume of fluids that can be withdrawn from geopressured sandstones. In addition geological interpretations enable models explaining the genesis and distribution of geopressured geothermal reservoirs to be formulated and refined.

Comparative structural interpretation on a regional scale is important (1) to understand why excess fluid pressure accumulates, (2) to identify factors that distinguish good prospects from poor prospects, and (3) to formulate structural models to aid exploration for and evaluation of areas where subsurface control is poor.

A genetic or depositional-systems approach was employed to gain understanding : of the relationships among stratigraphy, structure, and paleogeography in the Pleasant. Bayou, Blessing, and Cuero areas (fig. 1). Geological and geophysical studies had to be conducted simultaneously and interactively, with well data being used to refine the seismic interpretations and vice versa.

The history of syndepositional structures that create geopressured geothermal reservoirs can be reconstructed by means of sequential isopach maps. In the case of shallow-water deposition, it can usually be assumed that the amount of contem-: poraneous structural growth is much greater than the relief of depositional topography, so that an isopach map is essentially a paleostructural map. By removing the horizontal components of post-depositional fault displacement from the isopach map, an approximately palinspastic reconstruction can be obtained, Relative rates of fault movement are quantified in terms of the growth ratio (or expansion index), defined as the ratio of downthrown thickness to upthrown thickness. This type of analysis is particularly useful for structurally complex areas such as Pleasant Bayou. Whereas deep structure maps may show the superimposed effects of different tectonic regimes 


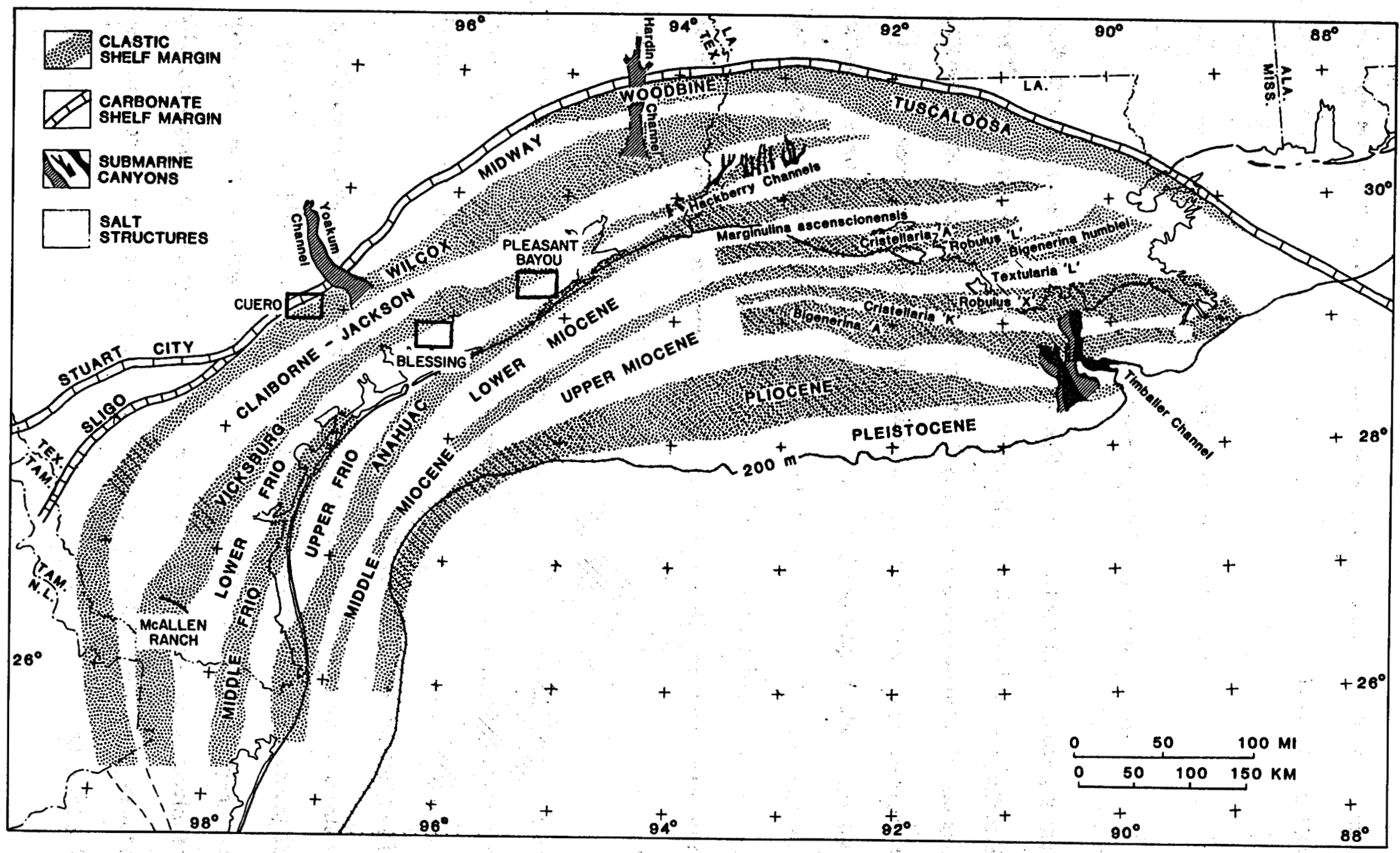

Figure 1. Location of Pleasant Bayou, Blessing, and Cuero study areas in relation to regional shelf-margin trends, northwestern Gulf of Mexico Basin. After Winker and
Edwards (in press). 
and deformational styles, individual isopach maps usually show a single style and are therefore easier to interpret.

\section{PLEASANT BAYOU AREA}

\section{Stratigraphic and Paleogeographic Setting}

Prospective geopressured aquifers in the Pleasant Bayou study area occur in the Anomalina bilateralis zone in the lower part of the Oligocene Frio Formation. Their absolute age is not well known because of a lack of datable material in the sequence and because paleontologic correlation in the Gulf Coast Basin has been based on benthic foraminifera, which have not been tied into global stratigraphic nomenclature based on planktonic microfauna. The lower Frio represents the maximum progradation of sandy facies in southeastern Texas during the Oligocene (table 1).

Both the Frio and the Anomalina bilateralis zone are informally defined stratigraphic units. For this study, the top of Frio (TO) picked by Bebout and others (1978) was not used. Instead, correlation markers were picked at the tops of major upward-coarsening progradational cycles within the Frio; these were assigned to benthic foraminiferal zones, according to an average of several wells in the area with micropaleontological data. In this report, the term "Frio" will refer to the interval from $T 2$ to $T 6$ of Bebout and others (1978).

The Pleasant Bayou area is situated within the Houston delta system (Galloway and others, in press), the lesser of two Frio delta systems in Texas (fig. 2). The larger Norias delta system to the south has previously been excluded from intensive geothermal exploration because the volcanically derived sandstones are diagenetically unstable, resulting in severe reduction of porosity and permeability by cementation (Loucks and others, 1979). 
Table 1. Characteristics of operational stratigraphic units in the Pleasant Bayou area.

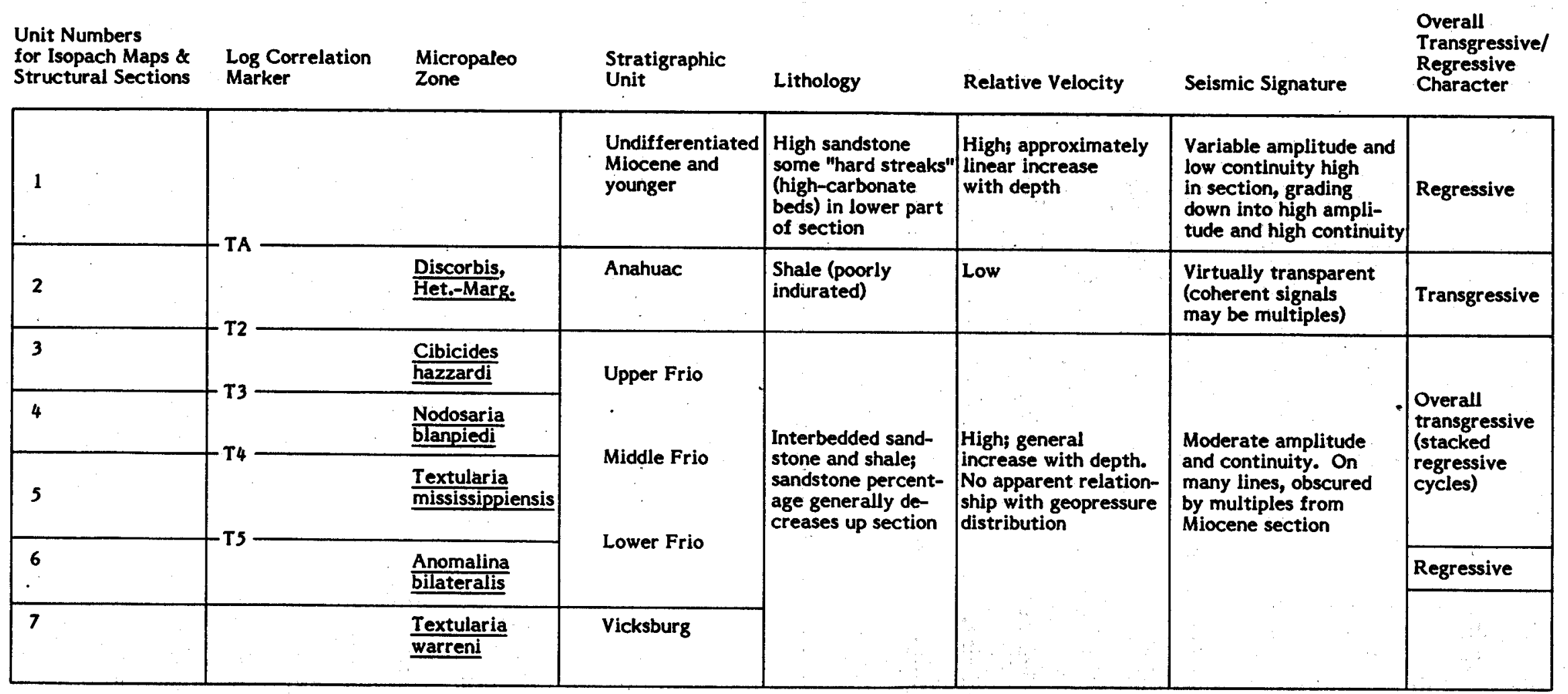




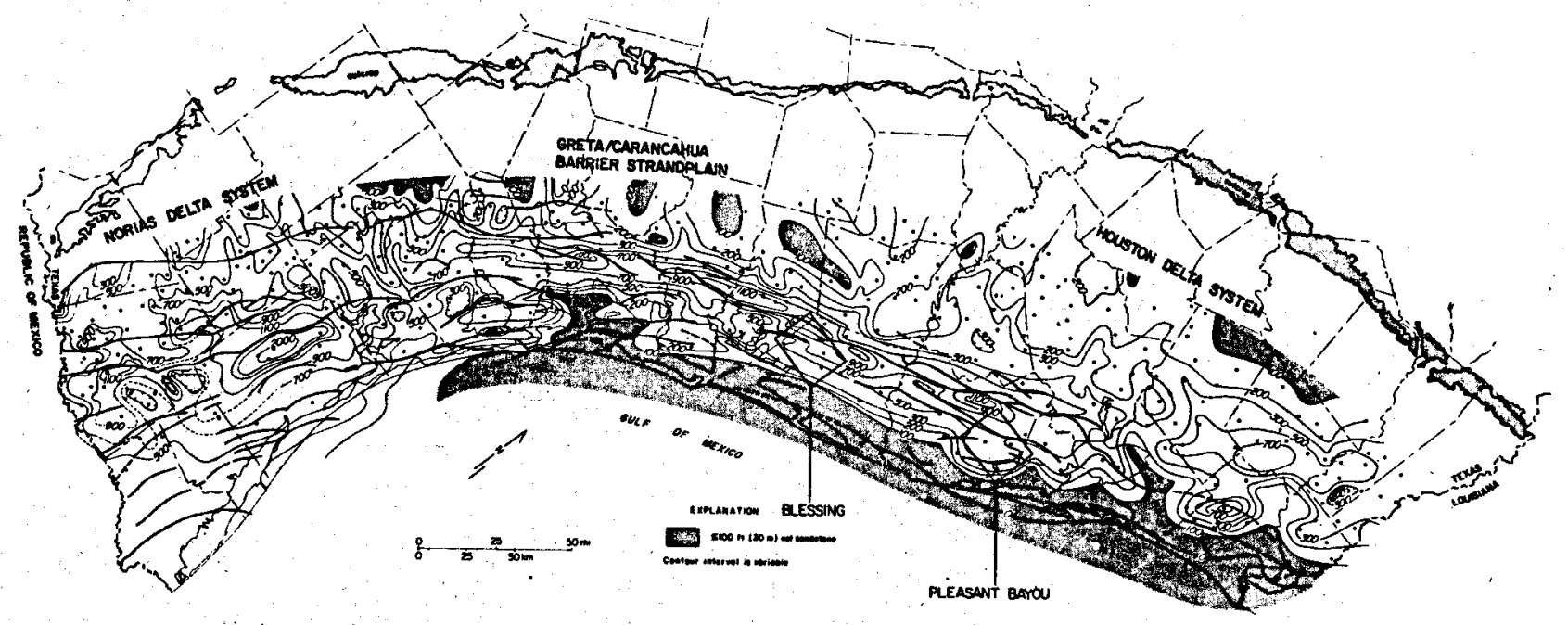

Figure 2. Location of Pleasant Bayou and Blessing study areas in relation to netsandstone thicknesses mapped for the lower Frio depositional systems in Texas. After: Galloway and others (in press). 
The Pleasant Bayou area is located within a zone of syndepositional down-to-thebasin faults that were most active during early Frio time. This fault zone also marks a rapid change in lithofacies, both in terms of sandstone percentage and in log character. Winker and Edwards (in press) interpret this relationship to mean that the Pleasant Bayou reservoir sandstones were deposited near the contemporaneous shelf edge (fig. 1).

\section{Operational Stratigraphy}

Site-specific description of the Pleasant Bayou area (fig. 3) began with the correlation of distinctive electric-log markers (fig. 4). Where possible, these were chosen at the tops of major progradational cycles and major lithologic breaks. Markers T2, T4, and T5 were used in earlier reports on the Pleasant Bayou area (Bebout and others, 1978; Flanigan, 1980). Operational stratigraphic units bounded by these markers were numbered sequentially from youngest to oldest (tables 1 and 2) to simplify labeling of maps and sections.

Log markers were transferred to nearby seismic sections using velocity-survey data from the Humble $\#_{1} 1$ Skrabanek well for conversion from depth to time. Markers were carried through the seismic grid as far as possible to check for internal consistency. Mis-ties of up to $100 \mathrm{~ms}$ were noted, but these did not show a clear regional trend.

Correlation was mostly straightforward. The only serious difficulties were encountered with the sub-T2 markers across the South Chocolate Bayou fault zone, where growth faults are closely spaced and exhibit large displacement and expansion of section. A tenuous marker was picked at the apparent base of the sandy Frio section for use in isopach mapping of interval 6 (table 1). 


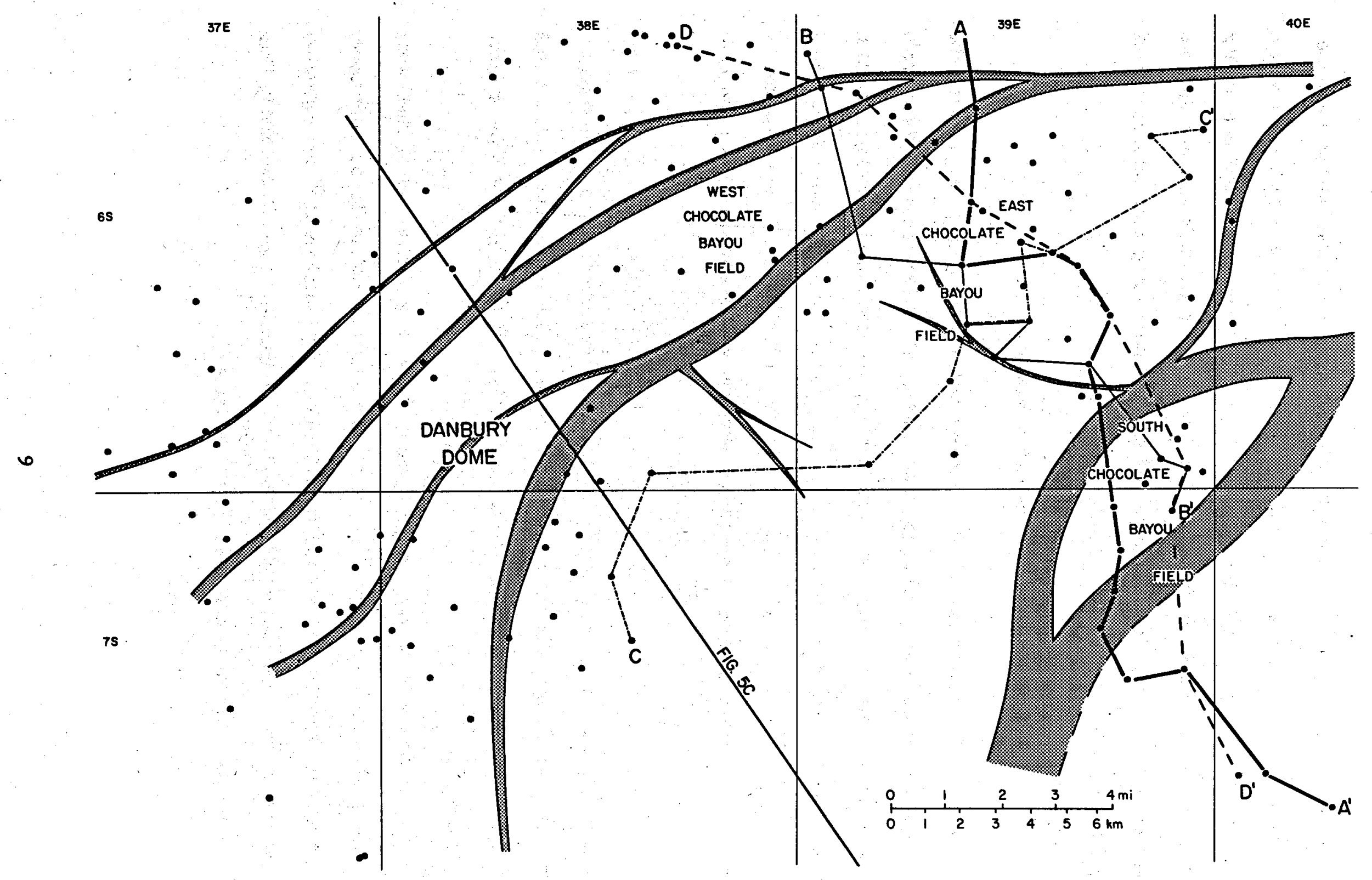

Figure 3. Data base and locations of sections in Pleasant Bayou area, Brazoria County. 


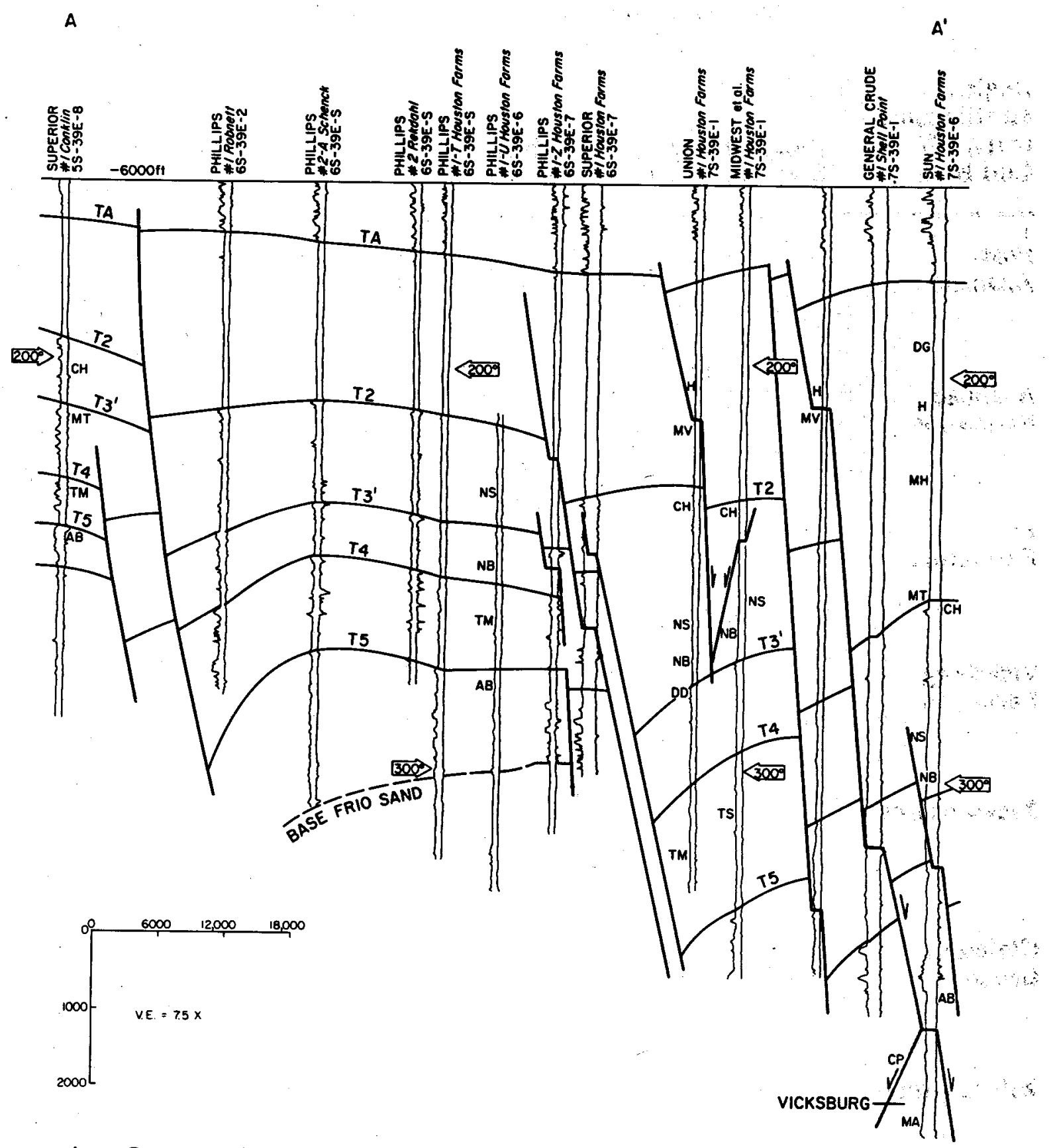

Figure 4. Structural dip section through Chocolate Bayou field, illustrating log character of stratigraphic units in Pleasant Bayou area (table 1). 
Table 2. Approximate stratigraphic position of log- and seismiccorrelation markers (TW, D1, TA, B1, etc.) and functional stratigraphic units $(1,2,3$, etc.) in four geothermal areas.

\section{Regional}

stratigraphic

units, NW

Gulf Basin

Pleasant Bayou, Brazoria County

$$
\begin{array}{ccc}
\text { Blessing, } & \text { Cuero, } & \text { McAllen Ranch, } \\
\text { Matagorda Co. } & \text { DeWitt Co. } & \text { Hidalgo County }
\end{array}
$$

Post-

1

1

Anahuac

Anahuac

TA

B1

Formation

2

2

1

B2

$\begin{array}{ll}\text { Frio } & \mathrm{T} 2 \\ \text { Formation } & 3 \mathrm{~T} 3 \\ & 4 \\ & 5 \mathrm{~T} 4 \\ & 6\end{array}$

3

$4 \mathrm{~B} 3$

$5 \mathrm{~B} 4$

6 B5

2

Vicksburg

Formation

7

7

3

4

5

Jackson Group

6

Claiborne

Group

Cl

2

Wilcox Group

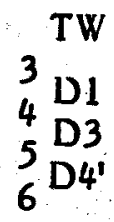

Midway Group 


\section{Structural Setting}

The location of the Pleasant Bayou area along the Frio growth-fault zone limits the potential size of Frio geothermal reservoirs. These growth faults resulted from large-scale basinward sliding of the continental slope, which created an extensional regime along the shelf margin (Winker and Edwards, in press). Frio growth faults tend to be more sinuous and widely spaced, with larger rollover anticlines, than growth faults in the Wilcox shelf margin.

The study area also lies within the Houston salt-structure province. Salt tectonics has superimposed a pattern of domes and withdrawal basins on the regional growth-fault structures, resulting in a complicated, multiphase structural fabric. Furthermore, well control is very uneven because most wells are drilled on or near the salt domes. For these reasons, seismic information is particularly important for structural interpretation away from structural highs.

\section{Local Structure}

Structure on five correlation markers was mapped using both well logs (fig. 3) and seismic data. A series of isopach maps was also constructed to interpret the structural growth history of the area. Well control is dense and was therefore the primary basis for structural mapping except in the salt-withdrawal basin between Danbury Dome and the Chocolate Bayou field where well control is sparse and structural mapping was based primarily on seismic data. In general, seismic data were used to verify the structural style, to check the direction and angle of fault dip, and to extend the structural interpretation below and downdip of the area of dense well control. The resulting structure map (fig. 8) on the zone of interest (T5) is a substantial departure from those maps obtained in earlier studies of this area (Bebout and others, 1978; Flanigan, 1980). 
Structural Style

The structural style in the Pleasant Bayou area (figs. 5-8) is typical of the Frio trend in the southeast Texas salt basin. Its early structural history also has elements in common with that of the Frio trend to the southwest, such as in the Blessing study area (fig. 1), which is dominated by shale tectonics. Characteristics of the Frio trend include highly sinuous growth faults with widely variable spacing ( $<1 \mathrm{mi}$ to $>5 \mathrm{mi}$ ), predominantly down-to-the-south offsets, large displacements (thousands of feet) and growth ratios (up to 10 ) at depth, and substantial rollover anticlines (landward dips as great as $\sim 20^{\circ}$ ). Displacements and growth ratios vary greatly along major faults. Where cut by wells, fault dips average around $45^{\circ}$. Most major growth faults flatten with depth, although no decollement surface is seen on seismic sections, unlike the Vicksburg trend (fig. 5D). Decollement is considerably deeper than in the South Texas Vicksburg trend, but the listric nature of these faults is evidenced by the substantial (rollover.

In the Pleasant Bayou area, three sets of down-to-the-basin faults cut the lower Frio (fig. 8). (1) A single fault of large displacement separates the East and West Chocolate Bayou fields and cuts through the Danbury Dome field. This fault is difficult to map properly except by use of sequential isopach maps. Its displacement decreases and probably dies out to the southwest. (2) Updip of this fault is a set of faults with closer spacing and less displacement. (3) In the South Chocolate Bayou field is a set of closely spaced faults of substantial displacement.

In addition to these major down-to-the-basin faults, small faults cut obliquely across the Chocolate Bayou fault block (fig. 8). The small fault in the Chocolate Bayou field is known from both well and seismic data; those near the test well are known only from seismic data. The origin of these faullts is not well understood, but they probably resulted from minor distortions of the large fault block during movement of its bounding faults. 


\section{A. CUERO}

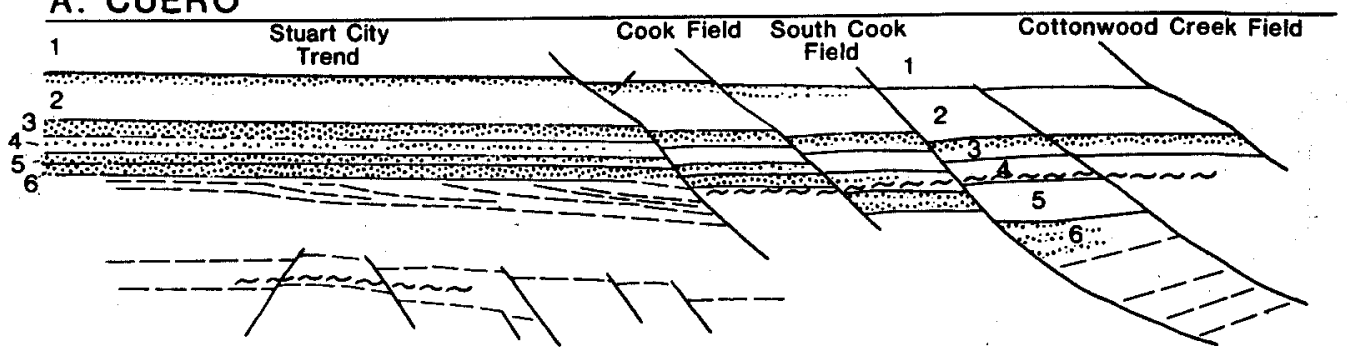

\section{B. BLESSING}

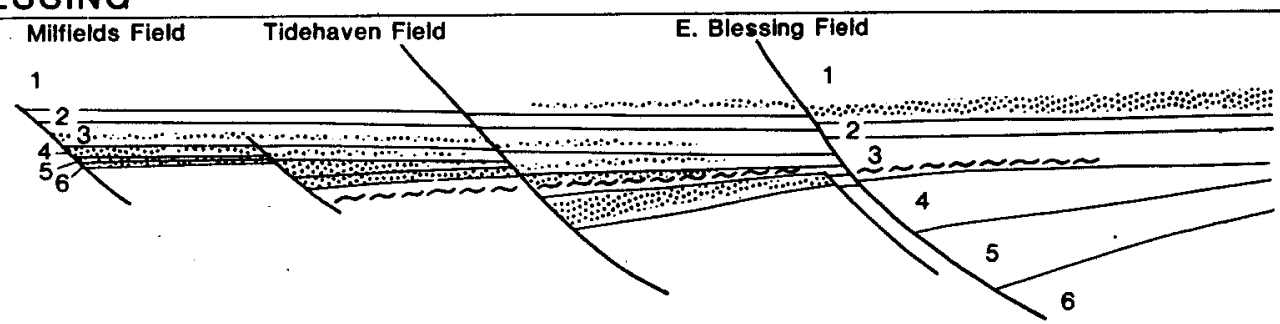

\section{PLEASANT BAYOU}

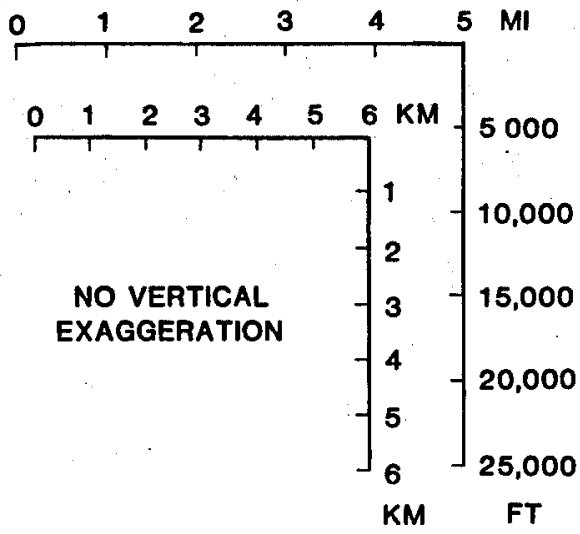

\%.W. MAJOR SAND

TOP OF GEOPRESSURE

CORRELATION MARKER

SEISMIC REFLECTOR

\section{MCALLEN RANCH}

El Benadito Field

McAllen Ranch Field

Monte Christo Fleld

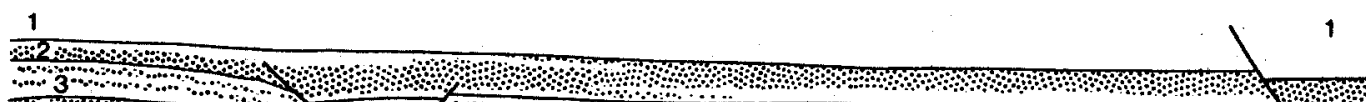

3.

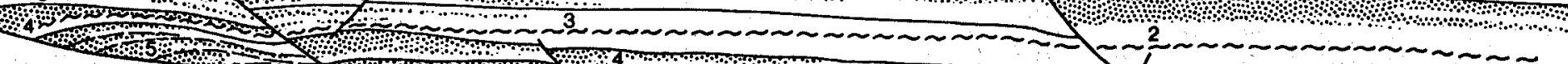

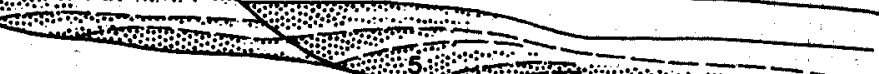

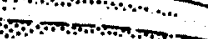
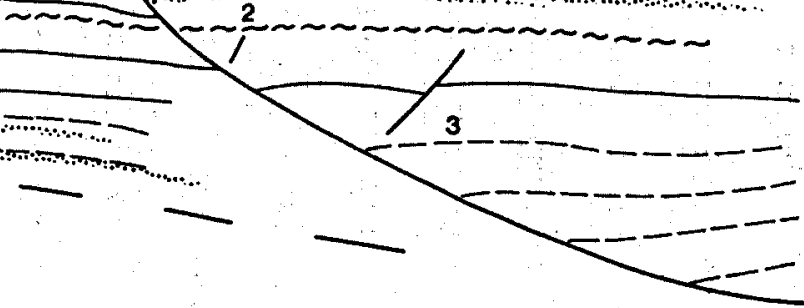

Figure 5. Dip sections of four geopressured geothermal study areas. Based on seismic sections and well control. After Winker and Edwards (in press). 


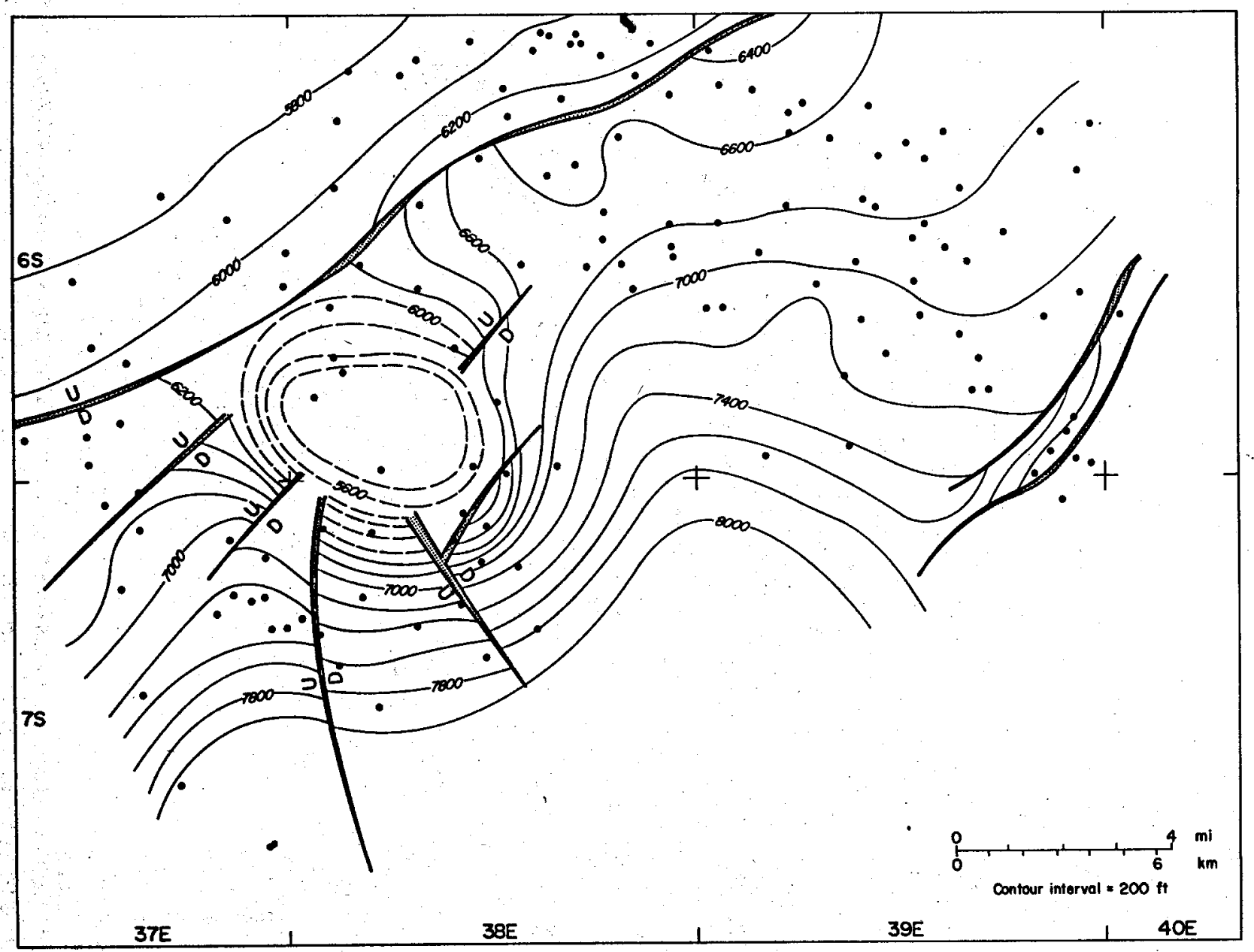

Figure 6. Structure contour map of TA marker (top of Anahuac). 


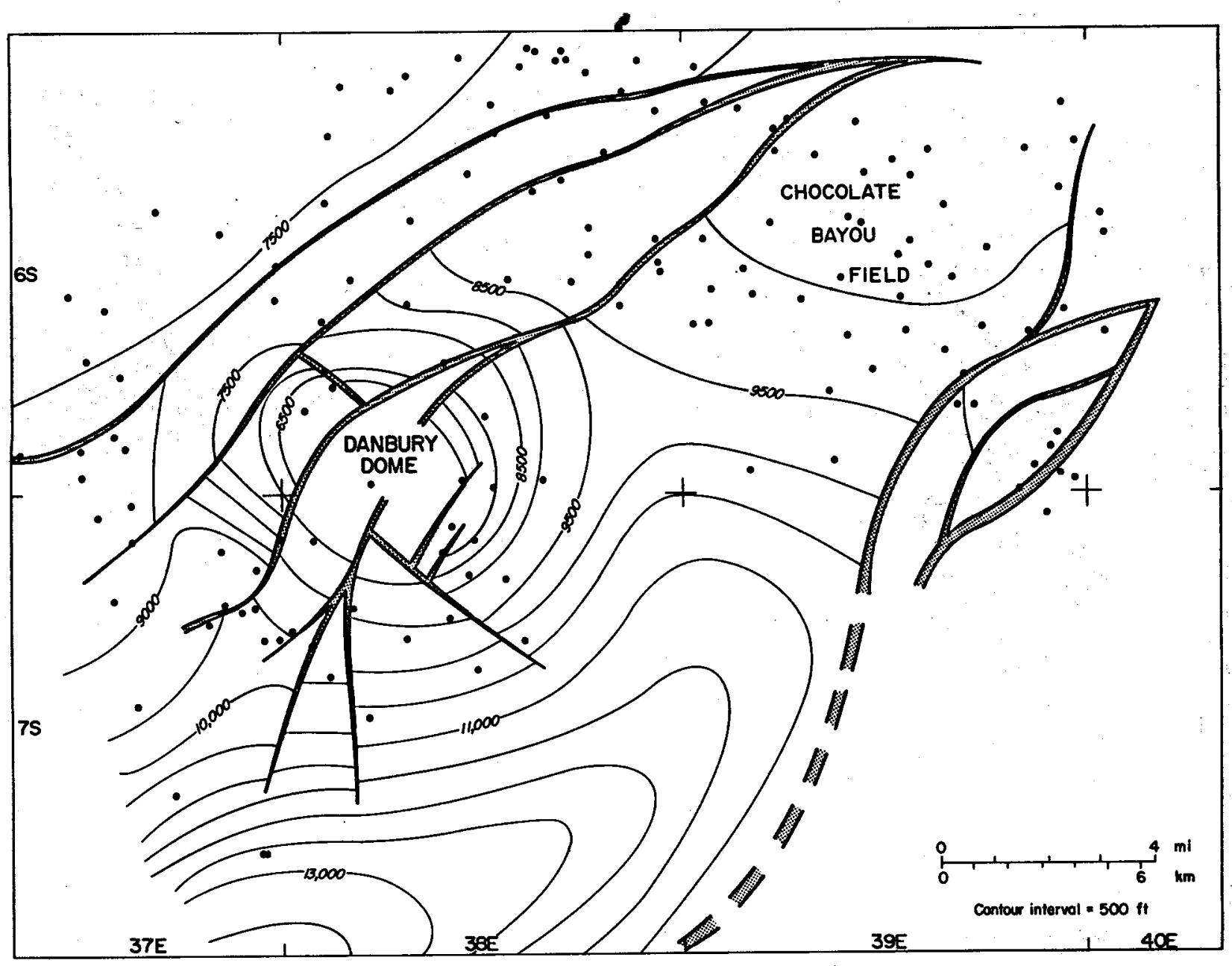

Figure 7. Structure contour map of T2 marker (top of first Frio sand and Cibicides hazzardi zone). 


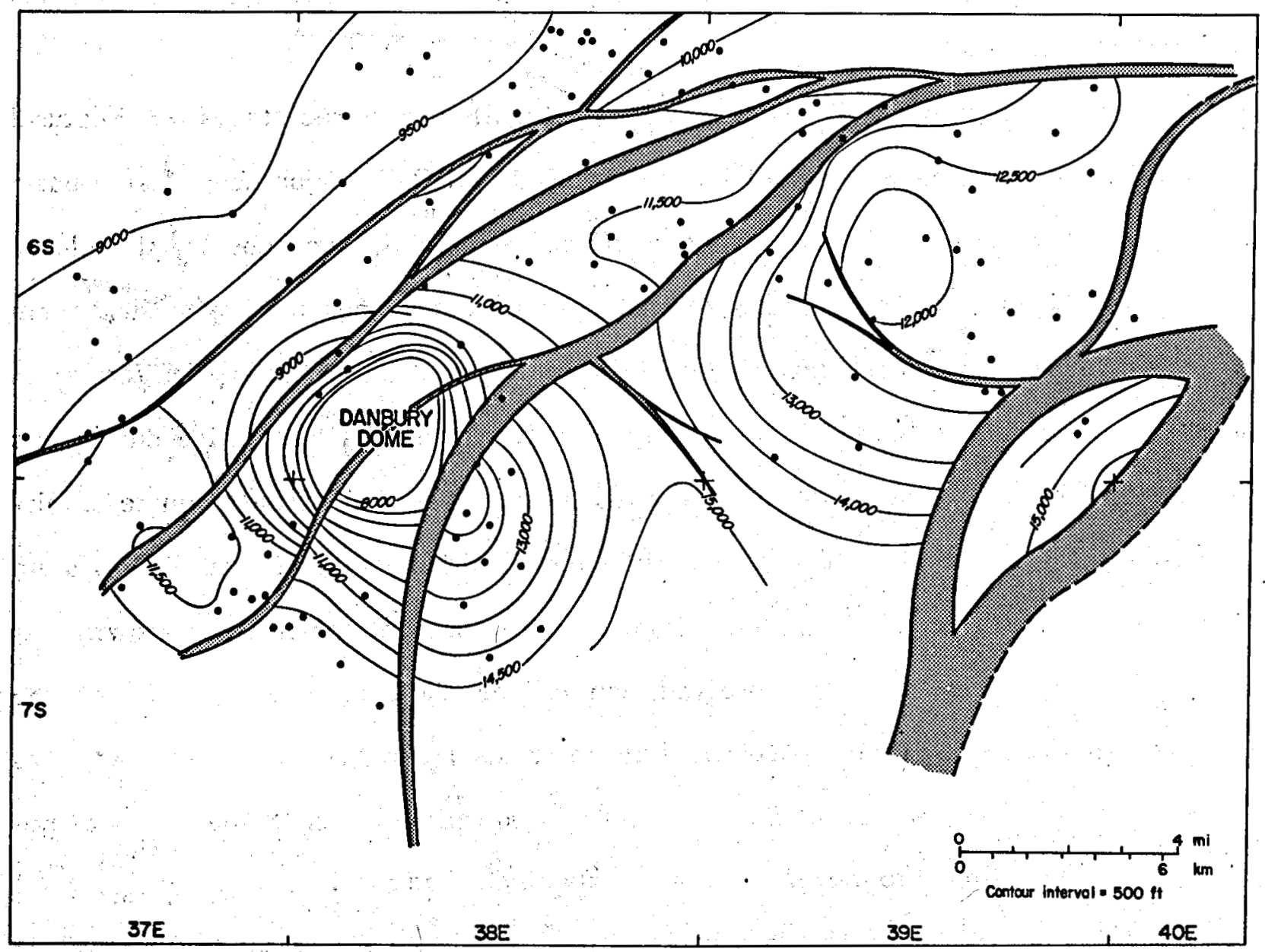

Figure 8. Structure contour map of T5 marker (top of Anomalina bilateralis zone). Structural relief is the greatest of any geothermal study area in Texas. 
Salt mobilization caused by the deposition of clastic sediments over salt led to the growth of Danbury Dome and an extensive salt-withdrawal syncline to the east and south. Arching of the strata over the growing dome resulted in the formation of radial faults (fig. 6) that are largely unrelated to the down-to-the-basin growth faults and do not cut the lower Frio.

\section{Structural Evolution}

Sequential isopach maps (fig. 9) allow recognition of three stages of structural evolution. (1) During early Frio time (intervals 5 and 6), a major down-to-the-basin growth fault formed. Growth ratios were as high as 6, and substantial rollover anticlines developed. This fault isolated downdip sandstones by juxtaposing them against older (Vicksburg?) slope shales, thus creating the seal necessary for formation of geopressure. The South Chocolate Bayou fault system was less active during this time. (2) During later Frio time (intervals 3 and 4), growth of the main reservoirbounding fault declined substantially, while the South Chocolate Bayou fault system became very active. This basinward shift in the locus of major fault growth was probably caused by basinward progradation of the shelf margin and thus of the extensional regime. (3) In post-Frio time (intervals 1 and 2), structural growth was dominated by deep-seated salt intrusion and related radial faults. Some down-to-thebasin faults continued to move, but at a greatly diminished rate.

Chocolate Bayou field apparently did not experience either salt withdrawal or uplift during the time interval covered by the isopach maps. A likely explanation is that this area experienced salt withdrawal early in its history, probably pre-Frio, while still in a continental-slope environment. Early salt-withdrawal basins (fig. 10) are common on the modern slope of the northwestern Gulf of Mexico (Lehner, 1969). Thus, Chocolate Bayou field may be analogous to "turtle structures" in the East Texas Basin and the North Sea, where broad structural closure is ultimately created in areas 

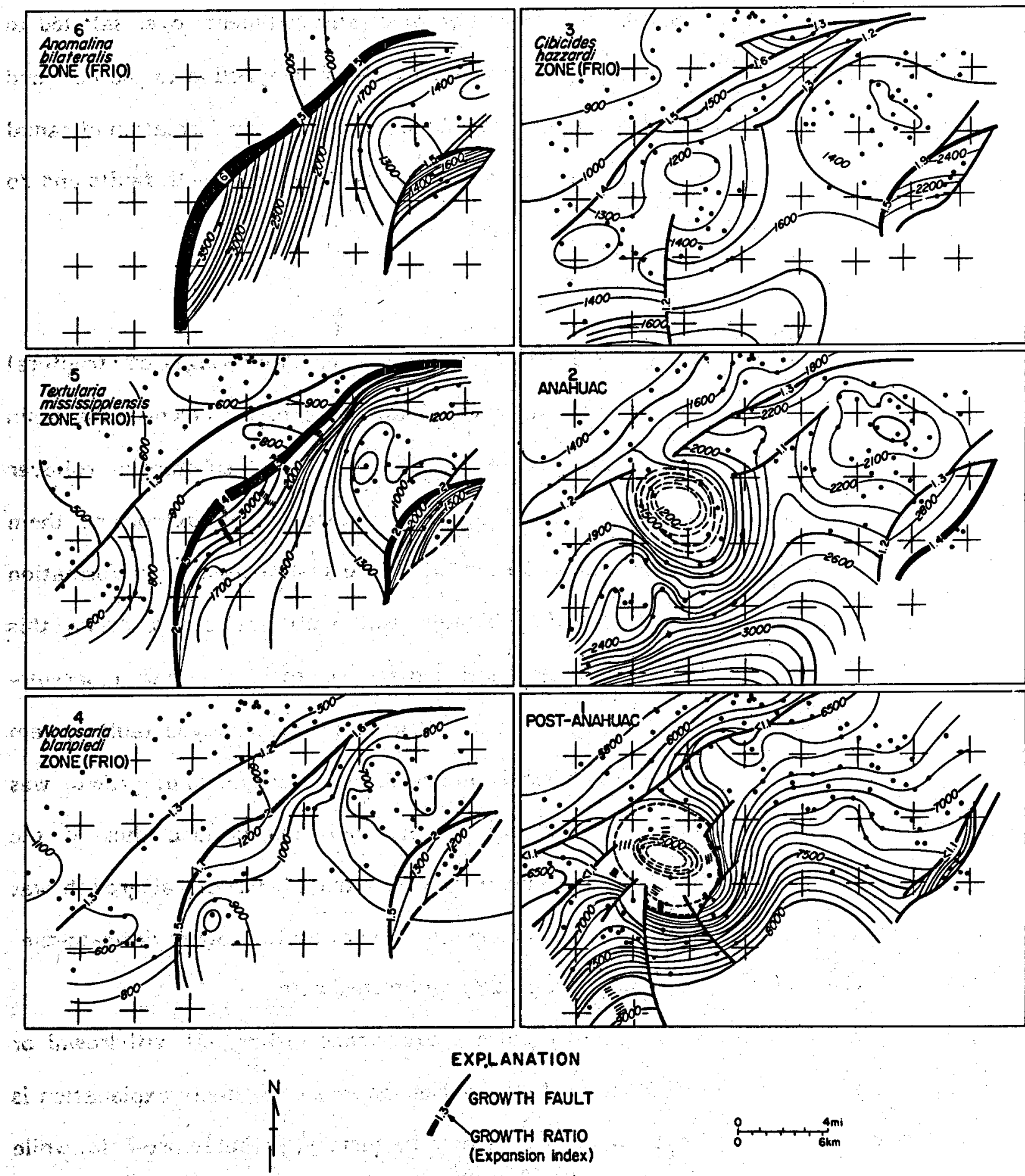

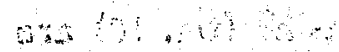

Isopach contour interval = $100 \mathrm{ft}$

Figure 9. Sequential isopach maps illustrating structural evolution of Pleasant Bayou study area: Distortion of grid is caused by removal of horizontal component of postdepositional faulting. Early movement was dominated by down-to-the-basin faulting with substantial rollover. Late movement was dominated by salt withdrawal and growth of Danbury Dome. 
A. Golden LANE SLOPE

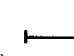
$10 \mathrm{MI}$

$10 \mathrm{KM}$

VERTICAL EXAGQERATION $=\mathbf{4}-7 \times$ SHELF BREAK $\ldots \ldots \ldots$ SHALLOW-SEATED
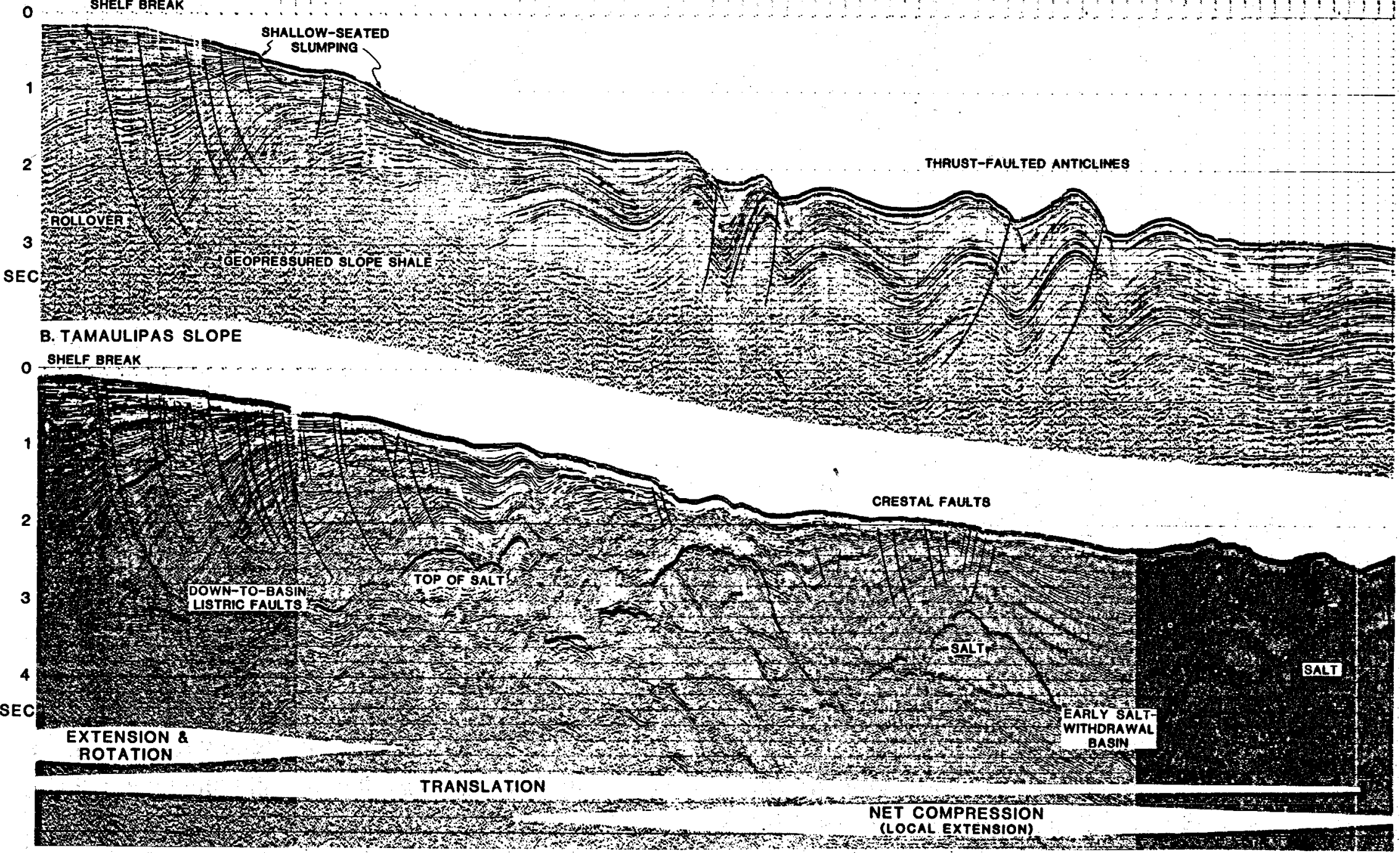

Figure 10. Seismic sections of modern continental slope, illustrating modern structural features analogous to Frio structures in Texas. Early salt-withdrawal basins may later form persistent broad structural highs like Chocolate Bayou field. 
of initial salt withdrawal. In the Chocolate Bayou field, rollover associated with growth faulting also helped to accentuate structural closure.

\section{Sandstone Facies}

Sandstone facies in the Anomalina bilateralis zone were classified on the basis of SP patterns and on continuity of individual sandstones. Four facies were recognized (table 3); these may represent different environments, but some of the differences in log character may be attributable to the large differences in subsidence rates (fig. 11). Spatial relationships among these facies are summarized by two stratigraphic sections (figs. 11 and 12) and by maps of $\log$ patterns for individual prospective sandstones (figs. 13, 14, and 15).

For reservoir evaluation, two kinds of facies variability that can be deduced from log patterns are considered significant: maximum thickness of an individual sandstone, and upward-fining, blocky, or upward-coarsening vertical trends. Upwardfining sandstones are generally thought to be channel or distributary facies, and tend to be thicker than upward-coarsening sandstones, although this relationship is not as well defined as in the Cuero study area. Aquifer permeabilities tend to be high, commonly greater than one darcy in the ' $A$ ' and ' $C$ ' sandstones; however, there is no obvious relationship between log pattern and maximum permeability. Nonetheless, we regard the thicker upward-fining or blocky sandstones to represent the best geothermal reservoir facies. These optimum sandstones are extensive (fig. 16); this, in combination with consistently high permeabilities, makes the Pleasant Bayou area an excellent geothermal prospect (table 4). The large salt-withdrawal syncline (fig. 8) places a large area of the ${ }^{\prime} \mathrm{C}$ sandstone off structure and away from current gas production. 
Table 3. Electric-log facies in the Anomalina bilateralis zone, lower Frio, Pleasant Bayou area.

Environmental

Interpretation

Characteristics

Geographic

Distribution

Fluvial/deltaic plain

High sandstone; blocky patterns; laterally discon-

Updip of main tinuous; total section thin growth fault

Blocky to upward-fining pattern. Thick sandstones with few shale breaks. Laterally

Distributary

channel and

channel-mouth

bar

Delta front

Delta front in rapid-expansion zone
Many thin sands interbedded with shale; difficult to correlate; very thick section
Downdip of main growth fault; patchy distribution

Widely distributed downdip of main growth fault

Near main growth fault on downthrown side 


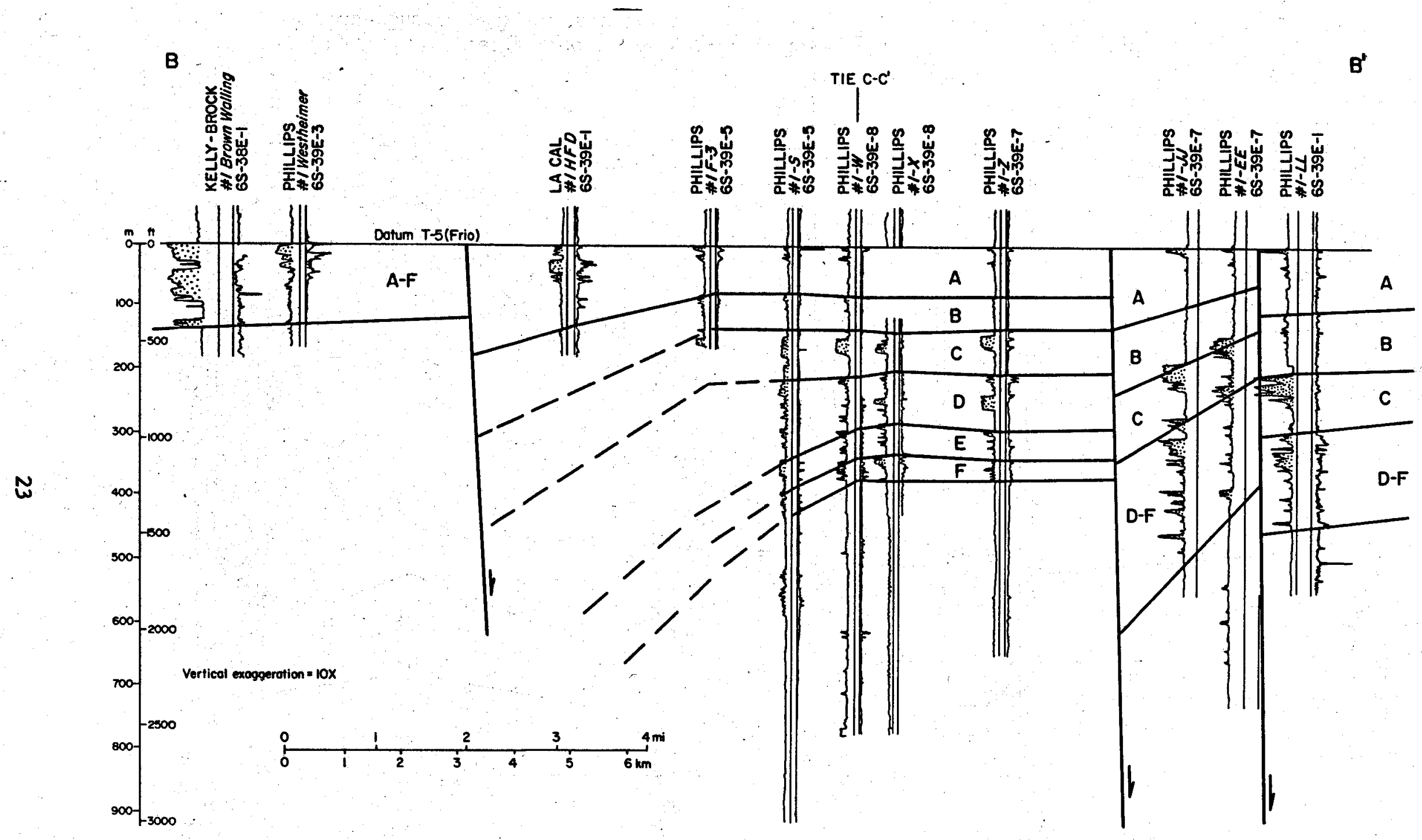

Figure 11. Stratigraphic dip section of lower Frio (Anomalina bilateralis zone), illustrating changes in log character due to extreme vertical expansion across growth fault. 


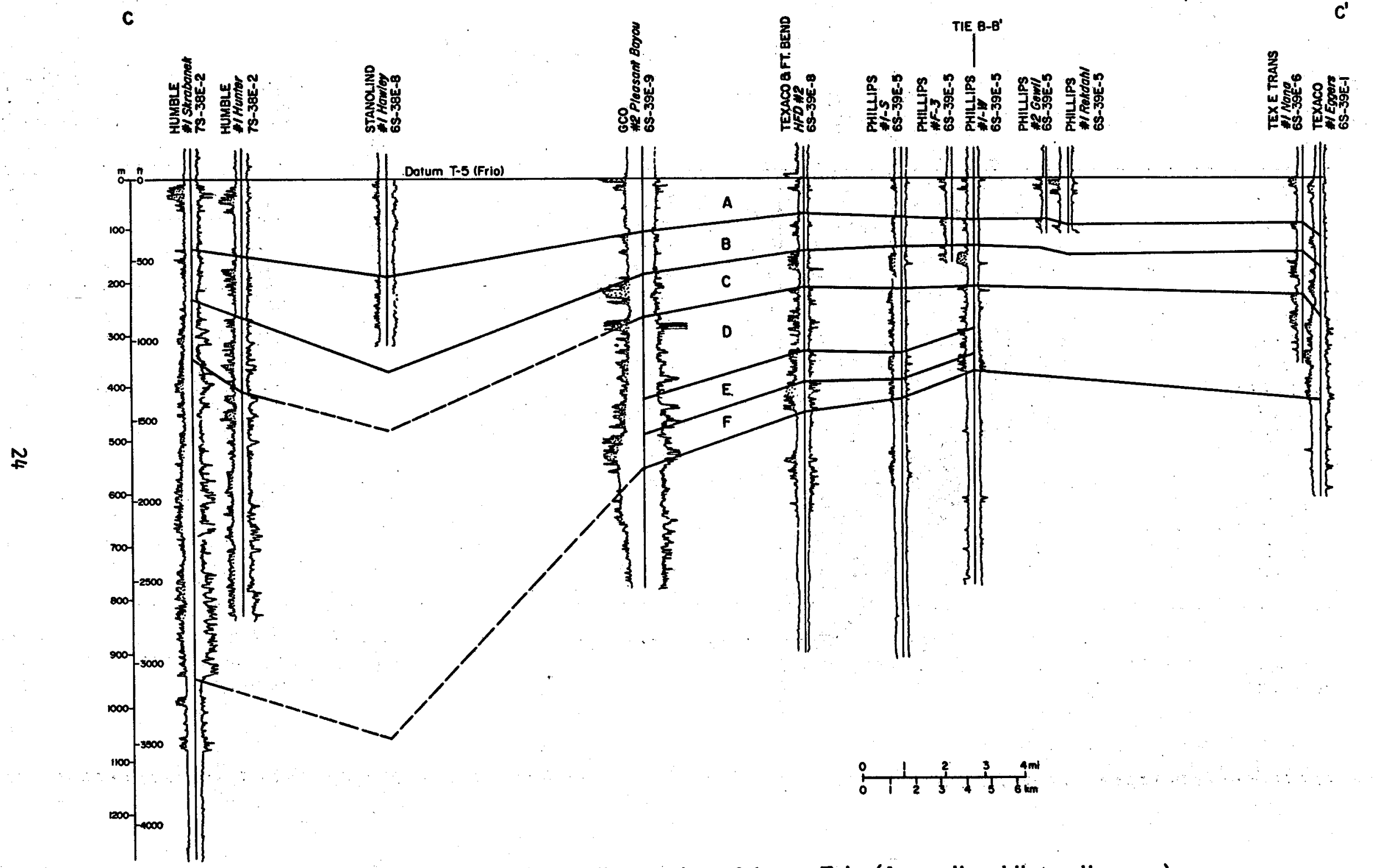

Figure 12. Stratigraphic strike section of lower Frio (Anomalina bilateralis zone), within Chocolate Bayou fault block. 


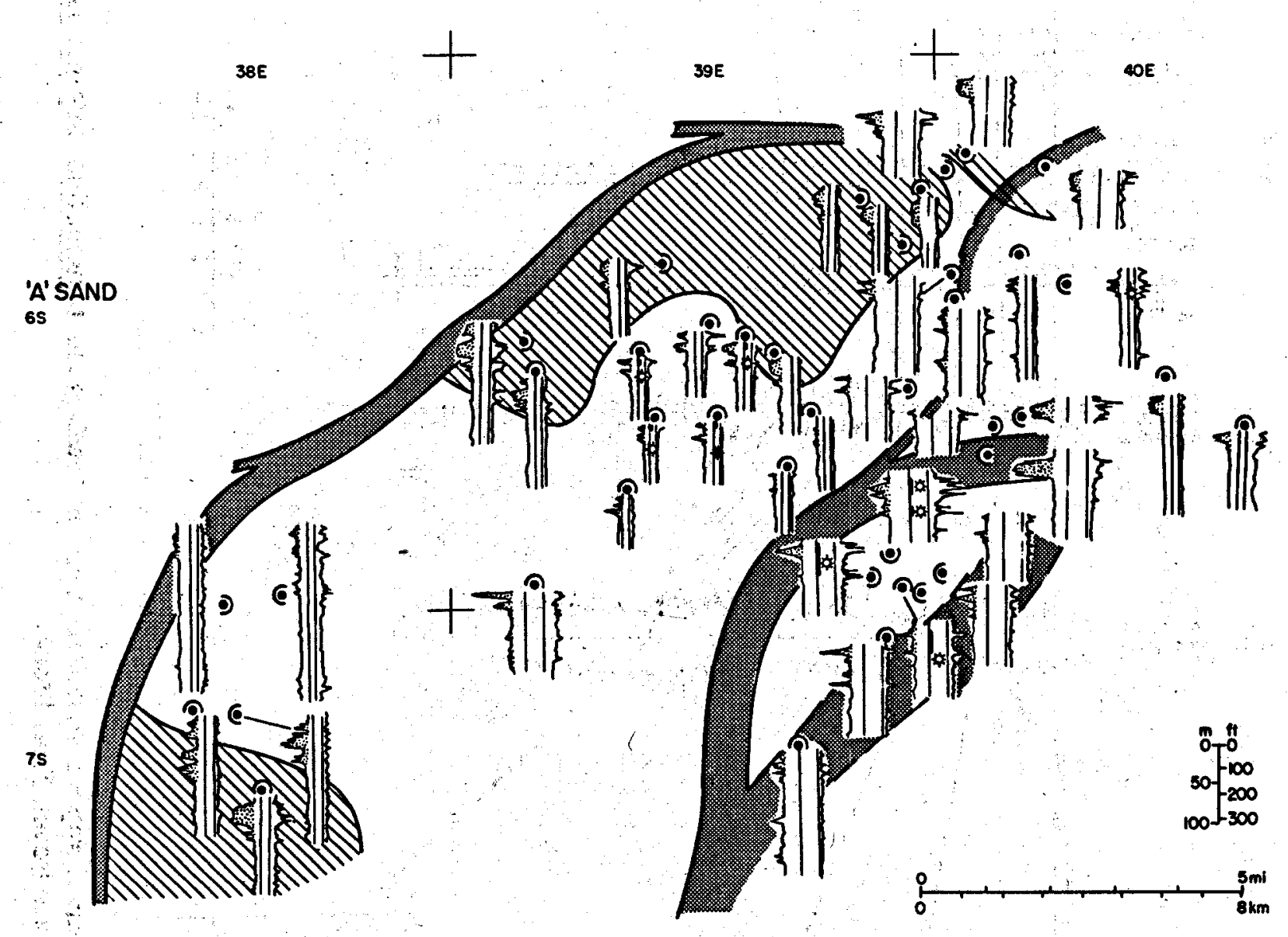

Figure 13. Log-pattern map of 'A' sand, lower Frio, with gas-well completions. 


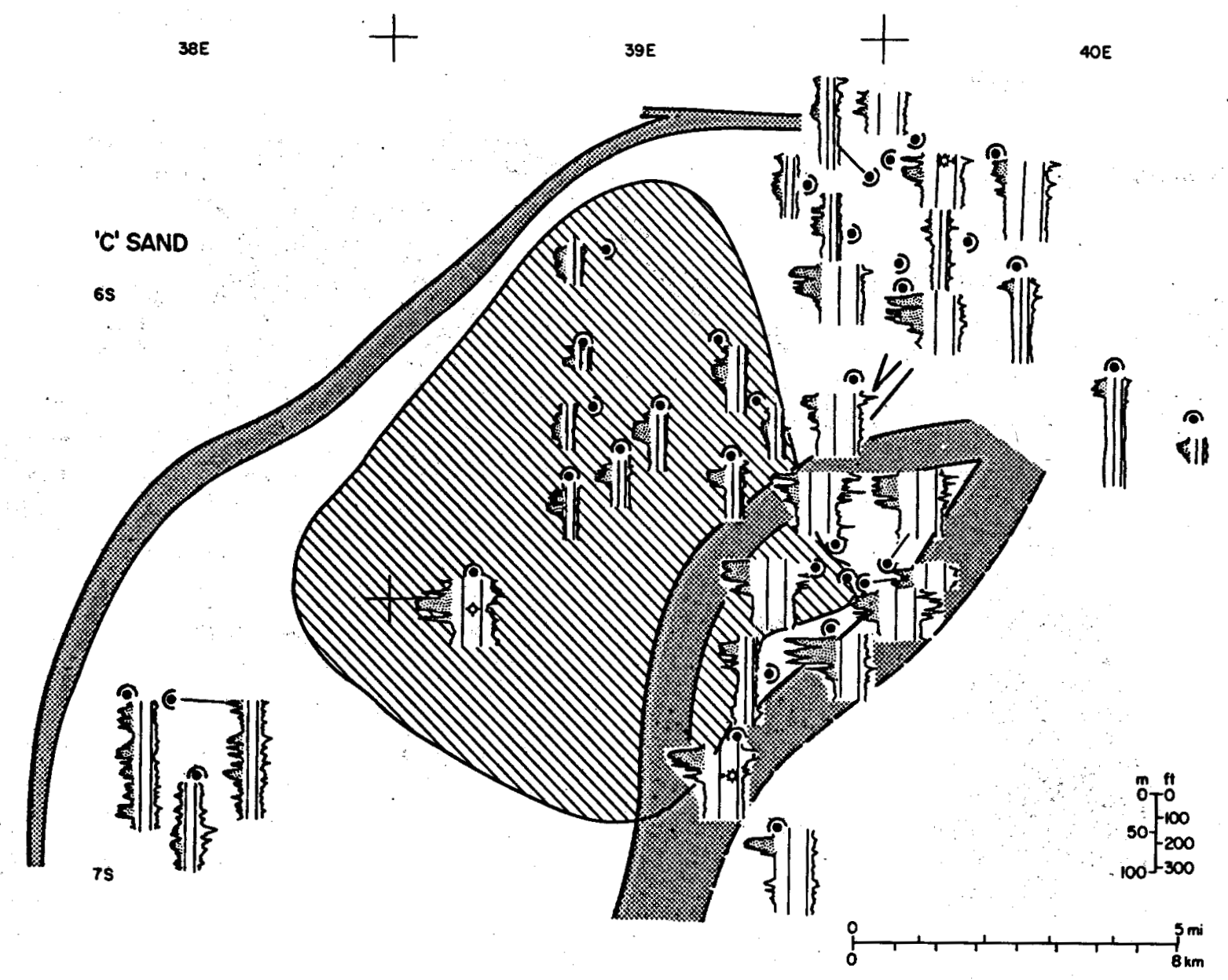

Figure 14. Log-pattern map of ' $C$ ' sand (geothermal reservoir sand), lower Frio, with gas-well completions. 


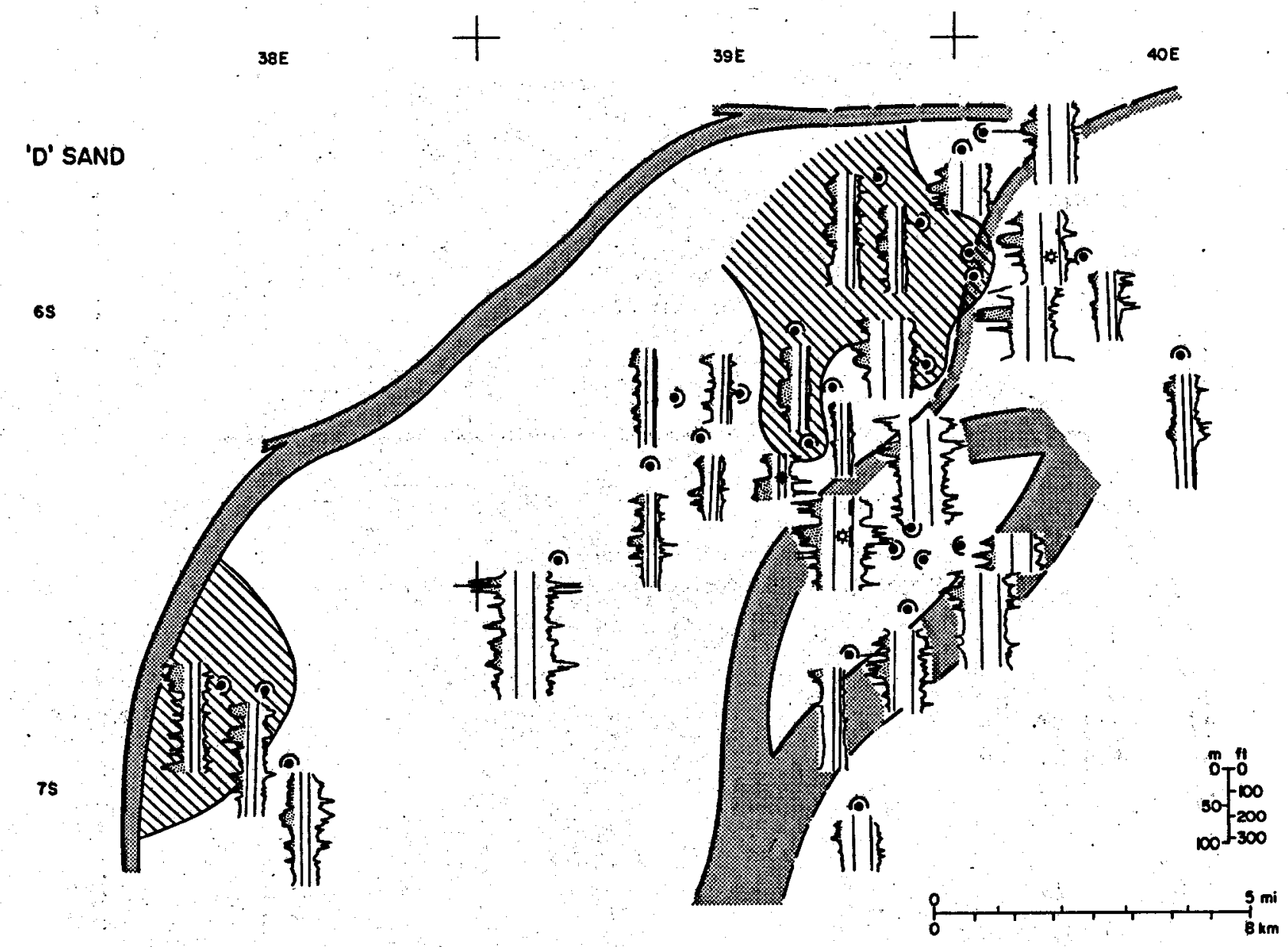

Figure 15. Log-pattern map of ' $D$ ' sand, lower Frio, with gas-well completions. 


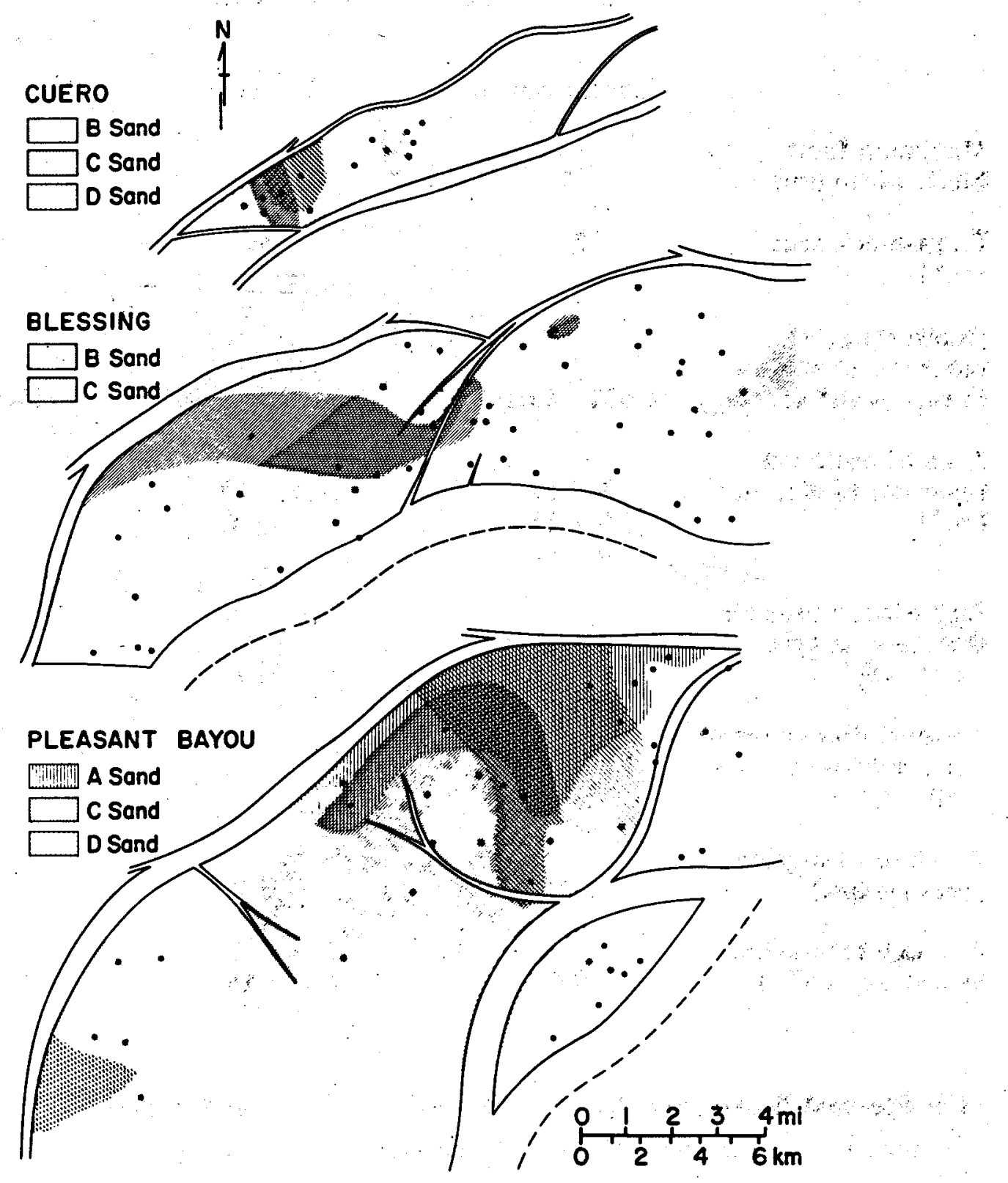

Figure 16. Distribution of optimum sandstone facies as inferred from electric-log patterns in three geothermal study areas. Areal extent and permeabilities of geopressured sandstones are best in the Pleasant Bayou area. 
Table 4. Reservoir parameters for three geothermal areas in the Texas Gulf Coast.

Pleasant Bayou

Maximum fault-

block width (mi)

Fault-block area $\left(\mathrm{mi}^{2}\right)$

Depth range of reservoir sandstones in type well* $(\mathrm{ft})$

Area of optimum reservoir sandstones $\left(\mathrm{mi}^{2}\right)$

Aggregate reservoir thickness in type well* (ft)

400

$0.01-515$ reservoir sandstones (md)

Average formation pressure (psi)

11,000

$B-10$

C -9

C -25

D -16

170

Average formation temperature $\left({ }^{\circ} \mathrm{F}\right)$
8,500

245

$0.01-56$

300
Cuero

10

12
200

$0.01-250$

$10,800-11,100$
$B-2.3$
$C-1.5$
$B-2.3$
$C-1.5$
D -0.4

D -0.4

8,250

285

*For Pleasant Bayou area, based on GCO-DOE \#2 Pleasant Bayou. 


\section{Pressure Distribution}

Pressure distribution in the Pleasant Bayou area has been described in three independent reports using different criteria for estimating formation pressures. Fowler (1970) plotted isobaric gradient lines on cross sections on the basis of proprietary test and production data (fig. 17). Bebout and others (1978) estimated an approximate average top of geopressure for the study area by plotting bottom-hole shut-in pressures (BHSIP) against depth (fig. 18). Flanigan (1980) estimated overpressure distribution in the study area by plotting shale resistivity, conductivity, and transit time against depth for individual wells and comparing these plots with type curves for normal compaction. The three parameters used by Flanigan indirectly measure shale consolidation and, by inference, overpressure (fig. 19).

Flanigan's (1980) interpretation of pressure distribution differs significantly from that of the other two in that he predicts the shallowest geopressure within the Anahuac Formation. Log parameters in the Anahuac deviate substantially from the normal compaction curve, suggesting fluid pressures above hydrostatic. However, mud weights indicate that the Anahuac can be drilled with the same low-weight muds (<13 lb/gal) used for drilling the normally pressured upper Frio (fig. 20). In drilling the General Crude-Department of Energy Pleasant Bayou test well, geopressure was not encountered until deep within the Frio section. Shale resistivities, conductivities, transit times, and interval velocities are apparently influenced strongly by factors other than fluid pressure, possibly including formation-water salinity, depositional environment, organic content, mineralogy, diagenesis, and flocculation behavior during deposition.

Except for the Anahuac, the various criteria provide a fairly consistent picture of pressure distribution. All criteria indicate that, updip of the reservoir fault block, Frio sandstones are normally pressured. Within the reservoir fault block, overpressure indicated by BHSIP's and mud weights is first encountered within the Frio section; 


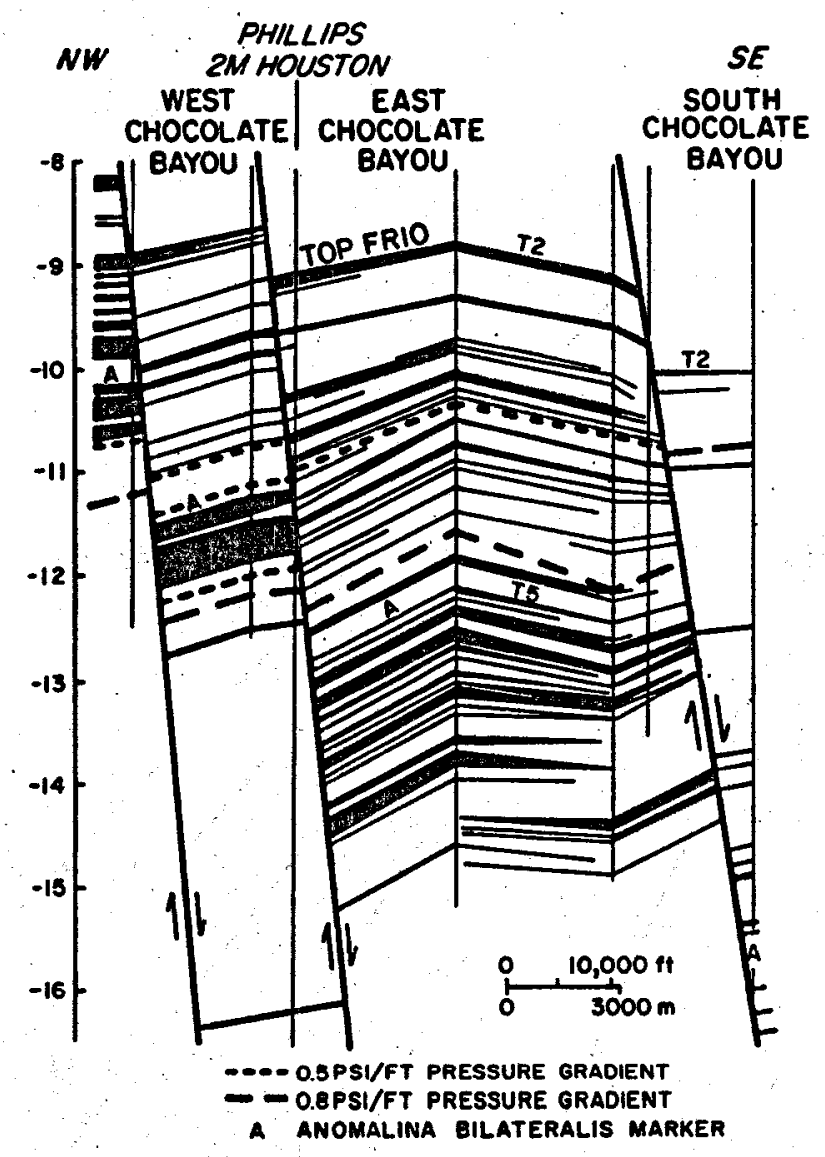

Figure 17. Distribution of pressure gradients across Chocolate Bayou field. After Fowler (1970). 


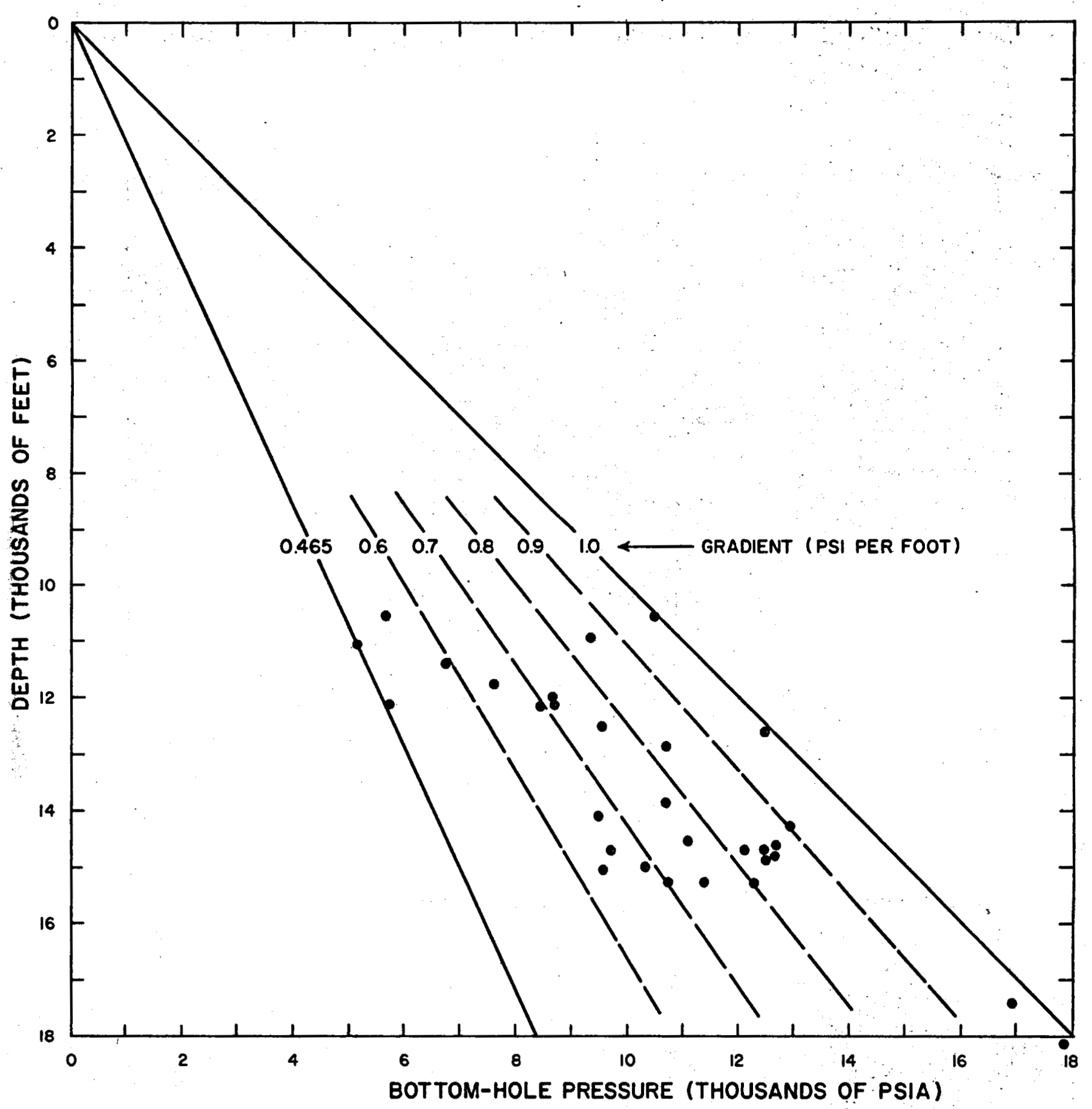

Figure 18. Static bottom-hole pressures versus depth for a number of wells, Chocolate Bayou field. After Bebout and others (1978). 


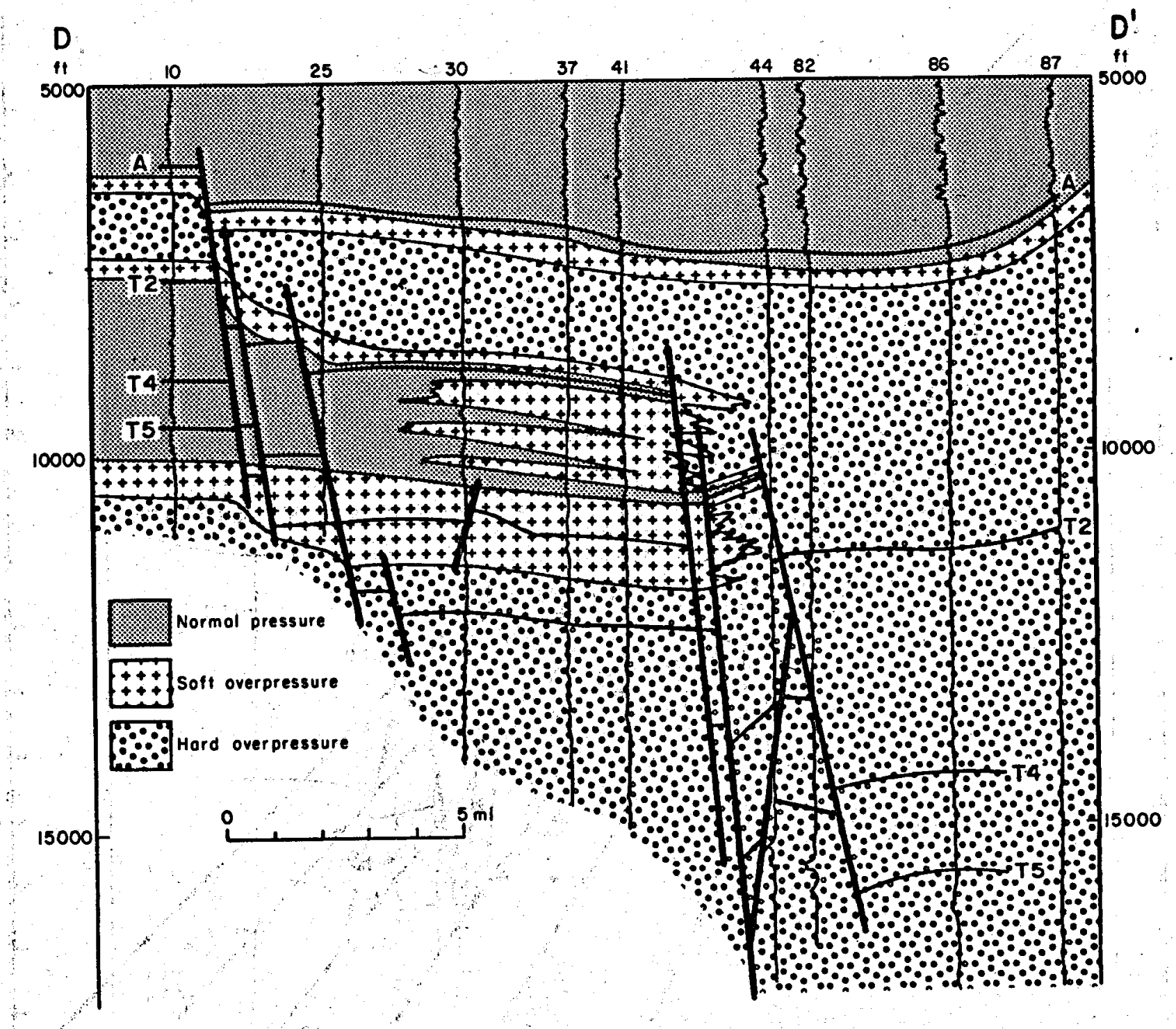

Figure 19. Distribution of pressure gradients across Chocolate Bayou field, according to Flanigan (1980). 


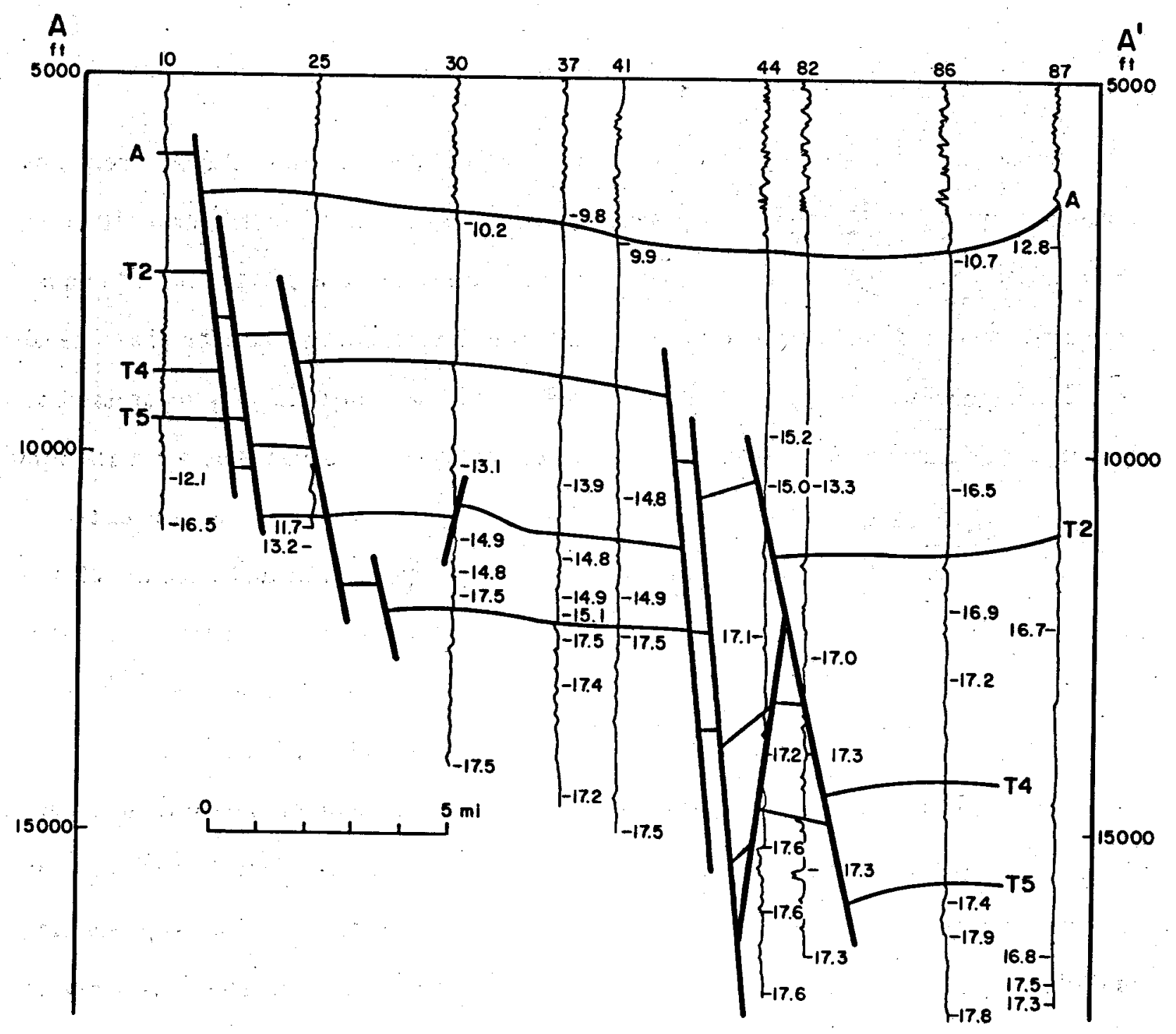

Figure 20. Mud-weight data for wells in cross section from figure 19. After Flanigan
(1980). 
pressure gradient is transitional from normal pressure to geopressure over a distance of about 1,000 ft. Downdip of the reservoir fault block, all of the Frio sandstones are overpressured. As a general rule, isograds follow bedding planes within fault blocks but may jump a few hundred feet across major faults (fig. 17).

\section{Seismic Studies}

Structural and stratigraphic interpretation of the Pleasant Bayou area was enhanced by $129 \mathrm{mi}$ of proprietary seismic data (fig. 21) that ranged from $>10$ yr to $<3 \mathrm{yr}$ old and was subject to a variety of shooting parameters and processing techniques (table 5). In this area, the most serious problem in interpretation was the presence of strong multiples at the depth of interest, which could have been largely suppressed by use of a long shot-receiver spread. Therefore, the General Crude-Western data set; which employed the longest maximum offset, exhibited by far the best data quality.

Because of the structural complexity of the prospect area and because of the wide variety of stratal and fault orientations, it is difficult to characterize the seismic sections in terms of strike and dip orientation. Nonetheless, some lines proved to have an optimal orientation, whereas others were located so as to be of little use.

Selected lines were reprocessed to ascertain the amount of potential improvement. Routine reprocessing of some of the General Crude and Mobil lines near the test well was subcontracted to Houston Processors Incorporated (H.P.I.). Reprocessing of Teledyne line 5-F was attempted with the Phoenix system at The University of Texas at Austin. From this reprocessing it was concluded that the recently shot and processed Western and Mobil lines do not benefit substantially from standard reprocessing, whereas the Teledyne lines benefit greatly. Consequently, standard production reprocessing (i.e., automatic residual statics, slower AGC, reworked stacking velocities, and migration) should be reserved for fairly old data ( 10 yr or more), 


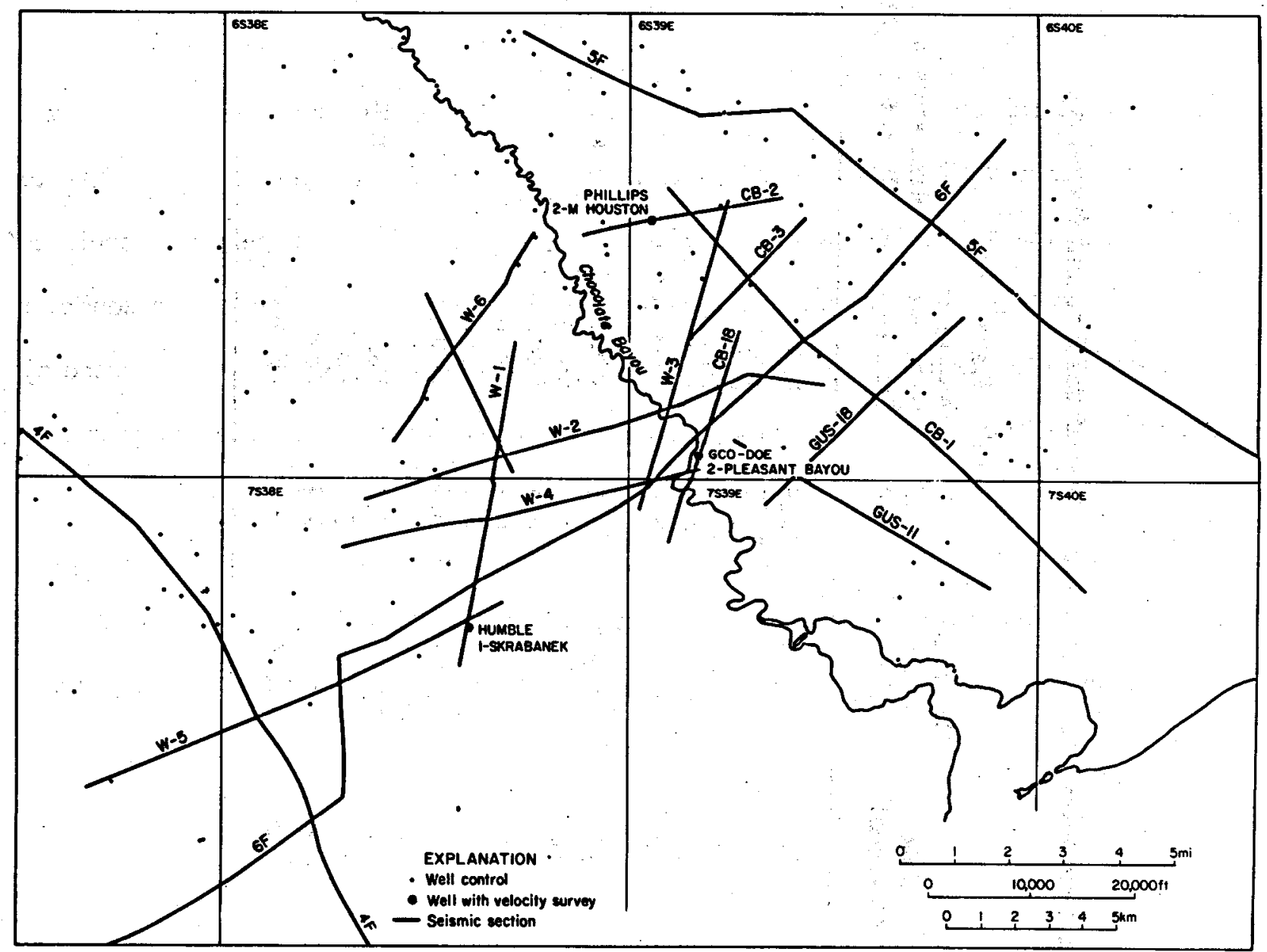

Figure 21. Base map of seismic data. Three Brazoria wells with velocity surveys (Humble 1-Angleton, Humble 1-Williamson, and Humble 1-Ward) are outside the area of this map. 
Table 5. Seismic lines acquired for evaluation of the Pleasant Bayou area.

\begin{tabular}{|c|c|c|c|c|c|c|c|c|c|}
\hline Line & Shot by & Date & $\begin{array}{l}\text { Fold } \\
\text { (Nominal) }\end{array}$ & $\begin{array}{c}\text { Maximum } \\
\text { Offset } \\
\text { (ft) }\end{array}$ & $\begin{array}{l}\text { Length } \\
\text { (mi) }\end{array}$ & $\begin{array}{l}\text { Data } \\
\text { Quality at } \\
\text { Depth of } \\
\text { Interest }\end{array}$ & $\begin{array}{l}\text { Reprocessed } \\
\text { by H.P.I. }\end{array}$ & Migrated & Orientation \\
\hline $\begin{array}{l}4 \mathrm{~F} \\
5 \mathrm{~F} \\
6 \mathrm{~F} \\
\text { GUS-11 } \\
\text { GUS-18 }\end{array}$ & $\begin{array}{l}\text { Teledyne } \\
\text { Teledyne } \\
\text { Teledyne } \\
\text { G.U.S. }\end{array}$ & $\begin{array}{l}5 / 69 \\
4 / 69 \\
8 / 69 \\
6 / 72 \\
8 / 72\end{array}$ & $\begin{array}{r}6 \\
6 \\
6 \\
12 \\
12\end{array}$ & $\begin{array}{l}8,250 \\
8,250 \\
8,250 \\
9,000 \\
9,000\end{array}$ & $\begin{array}{r}19.9 \\
16.2 \\
18.0 \\
6.3 \\
4.4\end{array}$ & $\begin{array}{l}\text { Fair } \\
\text { Poor } \\
\text { Fair } \\
\text { Fair } \\
\text { Poor }\end{array}$ & & $\begin{array}{l}x \\
x \\
x\end{array}$ & $\begin{array}{l}\text { Dip } \\
\text { Dip } \\
\text { Strike } \\
\text { Dip } \\
\text { Strike }\end{array}$ \\
\hline $\begin{array}{l}W-1 \\
W-2 \\
W-3 \\
W-4 \\
W-5 \text { (EN) } \\
W-5 \text { (NS) } \\
W-6 \\
C B-78-1 \\
C B-78-2 \\
C B-78-3 \\
C B-78-18\end{array}$ & $\begin{array}{l}\text { Western (for Gen. } \\
\text { Crude) } \\
\text { " } \\
\text { " } \\
\text { " } \\
\text { " } \\
\text { P.G.I. (for Mobil) } \\
\text { " } \\
\text { " }\end{array}$ & $\begin{array}{l}10 / 74 \\
11 / 74 \\
11 / 74 \\
11 / 74 \\
12 / 74 \\
12 / 74 \\
12 / 74 \\
11 / 78 \\
11 / 78 \\
11 / 78 \\
9 / 78\end{array}$ & $\begin{array}{l}12 \\
12 \\
12 \\
12 \\
12 \\
12 \\
12 \\
12 \\
12 \\
12 \\
12\end{array}$ & $\begin{array}{l}15,840 \\
15,840 \\
15,840 \\
15,840 \\
15,840 \\
15,840 \\
15,840 \\
10,780 \\
10,780 \\
10,780 \\
10,780\end{array}$ & $\begin{array}{l}5.9 \\
8.4 \\
6.6 \\
6.6 \\
8.4 \\
3.6 \\
4.4 \\
11.0 \\
3.1 \\
2.7 \\
3.7\end{array}$ & $\begin{array}{l}\text { Good } \\
\text { Good } \\
\text { Good } \\
\text { Good } \\
\text { Good } \\
\text { Fair } \\
\text { Poor } \\
\text { Fair } \\
\text { Fair } \\
\text { Fair } \\
\text { Good }\end{array}$ & $\begin{array}{l}\mathbf{x} \\
\mathbf{x} \\
\mathbf{x} \\
\mathbf{x} \\
\mathbf{x} \\
\mathbf{x}\end{array}$ & $\begin{array}{l}\mathbf{x} \\
\mathbf{x} \\
\mathbf{x} \\
\mathbf{x}\end{array}$ & $\begin{array}{l}\text { Oblique } \\
\text { Oblique } \\
\text { Oblique } \\
\text { Oblique } \\
\text { Oblique } \\
\text { Dip } \\
\text { Strike } \\
\text { Dip } \\
\text { Dip } \\
\text { Oblique } \\
\text { Oblique }\end{array}$ \\
\hline
\end{tabular}


whereas more recent data should be reprocessed only for a specific purpose such as waveform studies or for comparison with synthetic seismograms.

\section{Mobil CB-78-1}

This line best demonstrates the structural style of the bounding faults of the reservoir fault block (fig. 22). On the northwestern (updip) end of the section is a single fault with large displacement and rollover. Unfortunately, the seismic line does not extend far enough updip to show the upward extension of this fault. To the southeast (downdip) is a series of faults of large displacement but with relatively little rollover; traps created by these faults constitute the South Chocolate Bayou field. Between the updip and downdip faults, this seismic line traverses the Chocolate Bayou field, a broad low-relief dome. A small fault crosses the Chocolate Bayou field nearly parallel to the seismic line and intersects the line within the Frio interval. As a result, the Frio is difficult to interpret on this line even after migration (fig. 22).

Data quality deteriorates severely at Frio depths in the South Chocolate Bayou fault zone. The reason for this is not evident, but may be related to the problem of "wipe-out" zones beneath major faults as seen in the Cuero area. At depth in the South Chocolate Bayou area, migration does not improve the image and may even worsen it.

Nonetheless, migration resulted in considerable improvement of the rest of the seismic image. Most evident was the improved clarity and sharpness of the South Chocolate Bayou faults where they cut the Miocene section (fig. 23). Migration also resulted in a more accurate representation of the rollover geometry. Migration did not help the seismic image where the small Chocolate Bayou fault cuts the seismic line in a near-strike orientation. The two-dimensional migration algorithm assumes a true-dip orientation for all dipping reflectors, and deviation from this assumption can result in deterioration rather than improvement of the image by migration. Migration 


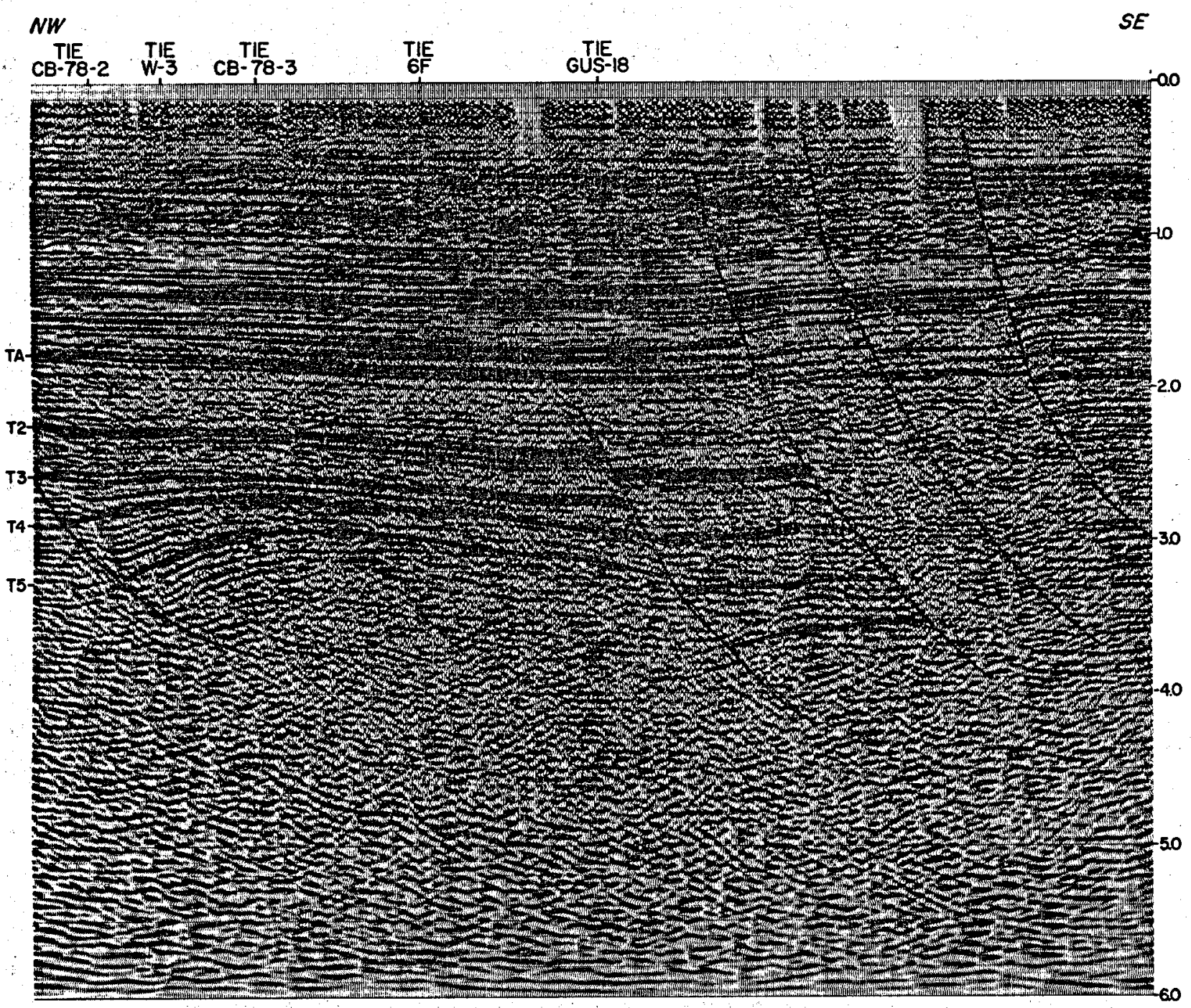

Figure 22. Mobil line $C B-78-1$, after reprocessing and migration. This line best demonstrates the styles of regional down-to-basin growth faults and the structural setting of the Chocolate Bayou and South Chocolate Bayou fields. 
sw

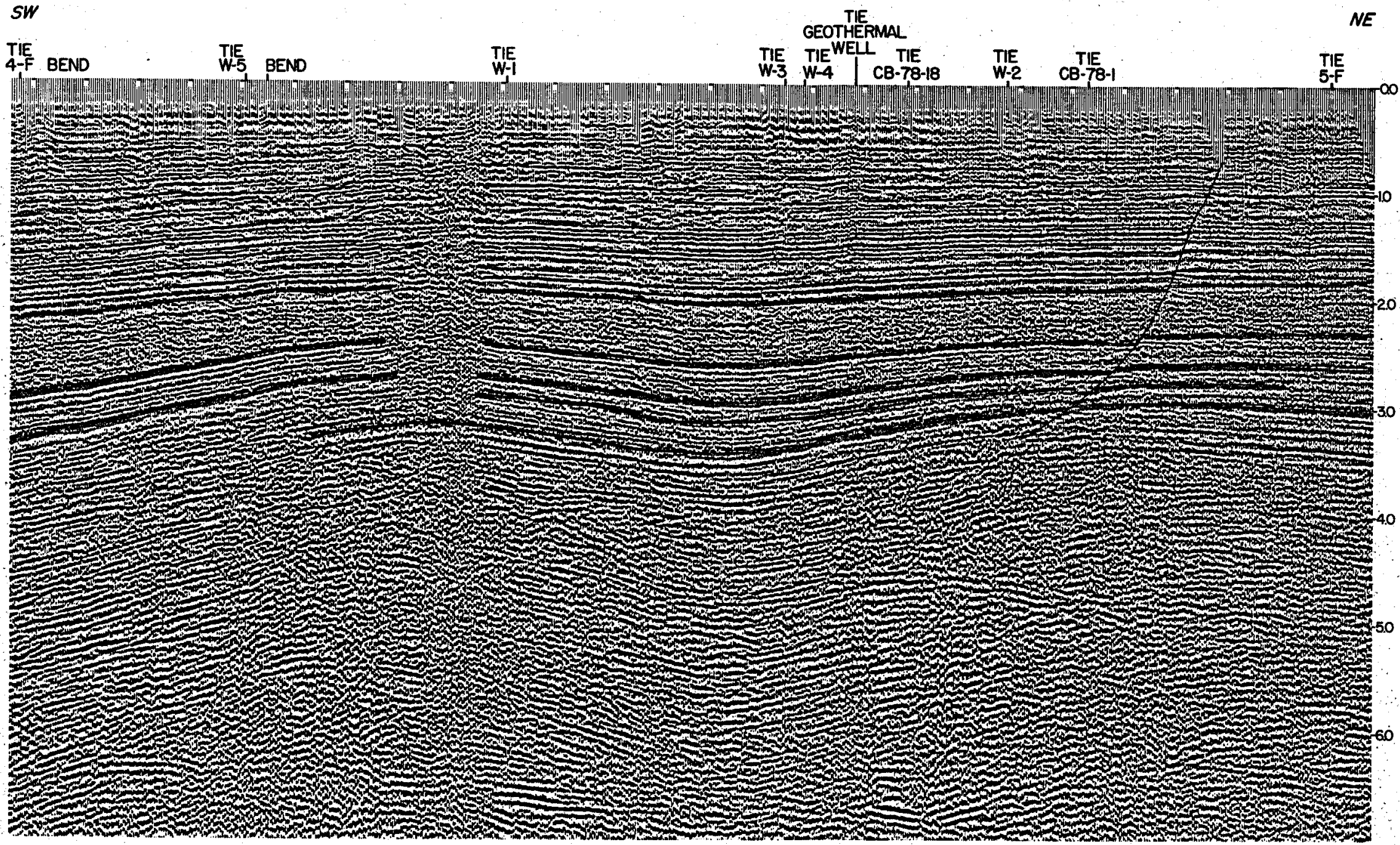

Figure 23. Teledyne line $6 \mathrm{~F}$, after reprocessing and migration. This is a strike line approximately down the middle of the Chocolate Bayou field. To the west, dominance of salt withdrawal is apparent. 
commonly creates the impression that the faults are listric near the base of the section. In the Frio, this inference is often a valid one, but may also be an artifact created by migrating noise.

Reprocessing of $\mathrm{CB}-78-1$ was probably unnecessary. Application of automatic residual statics and reworked stacking velocities did not significantly improve the image in the South Chocolate Bayou fault zone as was hoped. Minor improvements in coherence and continuity were observed, but not enough to improve the interpretability of the section.

\section{Teledyne 6-F}

This is essentially a strike line running down the center of the reservoir fault block; it ties the Chocolate Bayou field on the structural high with the geothermal well on the flank of the syncline (fig. 23). It shows structures resulting primarily from post-Frio salt mobilization rather than from growth faulting during Frio' time. It is also properly oriented to show the small down-to-the-west fault that cuts the Frio in the Chocolate Bayou field. Seismic signature in the Frio suggests high continuity, but some of this may be due to multiples of the Miocene section.

\section{Western W-4}

This is an example of a seismic line that does not follow the regional dip but is nevertheless ideally oriented to show certain structures. It ties the Pleasant Bayou \#2 geothermal test well on the east end with the updip-bounding growth fault on its west end (fig. 24). Most significantly, it shows the small faults that cut the lower Frio near the test well. These small faults are not immediately apparent on the section, and their exact position is speculative. Their presence was detected by tying the $T-4$ and T-5 reflectors to Humble \#1 Skrabanek and the geothermal test well. Although the exact position of these faults is not known, their displacement is clearly down-to-thewest. 


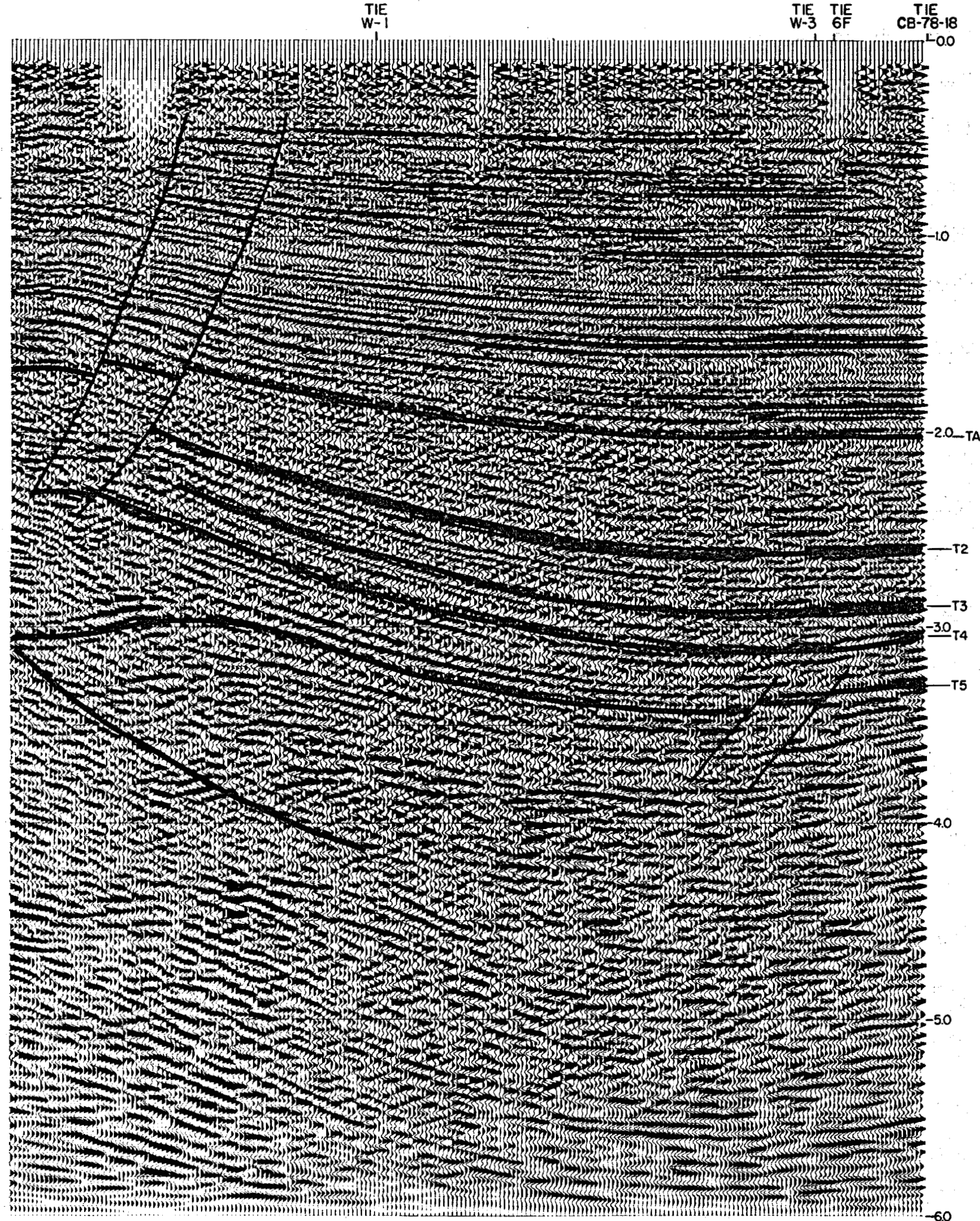

Figure 24. Interpreted version of line W-4, after reprocessing and migration by H.P.I. Deep faults near the geothermal well were inferred by tying loops in the Western grid. 
As with $C B-78-18$, reprocessing resulted in only minor changes in the seismic image of W-4. Migration improved the accuracy of the rollover anticline near Danbury Dome, but had relatively little effect on the interpretability of the small faults near the geothermal well.

Overall, this line is one of the best in the area in terms of data quality at the depth of interest. This high quality can be attributed primarily to the long offset, resulting in adequate suppression of multiples.

\section{Western W-3}

This line nearly ties the geothermal well and runs obliquely to the updip-bounding growth fault without meeting it. Data quality is slightly poorer than that of $W-4$, and reflector continuity in the Frio suffers somewhat (fig. 25). Reprocessing resulted in slight improvement in reflector continuity. Migration did not help this line because there is significant dip across the line rather than with it.

\section{Western W-1}

This line parallels W-3 to the east (fig. 21); unlike W-3 it crosses the updipbounding growth fault of the reservoir fault block. This bounding fault is seen on this line at nearly its maximum displacement and growth ratio; expansion of the Frio section into the fault is readily evident (fig. 26). The anticlinal closure was created by post-Frio salt withdrawal that tilted the area of the line southward.

\section{Western W-5}

This line also shows the updip-bounding growth fault to advantage (fig. 27), but at a point somewhat to the south of its maximum displacement. Expansion of the individual lower Frio units across the fault is evident. The fault is also seen to die out upward in the undifferentiated Miocene section. As a general rule, this fault dies out either in the Miocene section or within the Anahuac. 


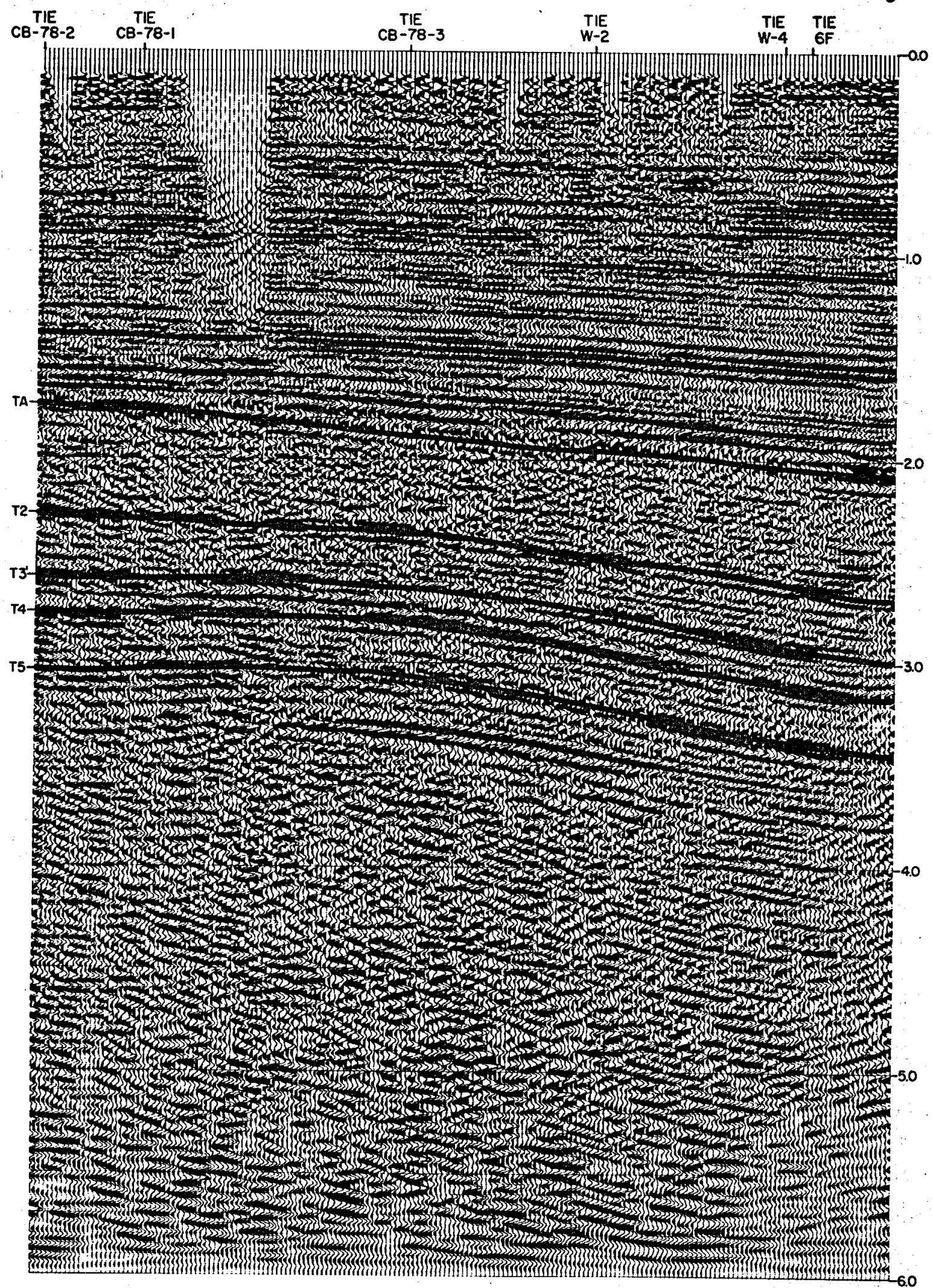

Figure 25. Line W-3, after reprocessing and migration by H.P.I. Line does not benefit from migration because most of the dip is across the line. 
$N$

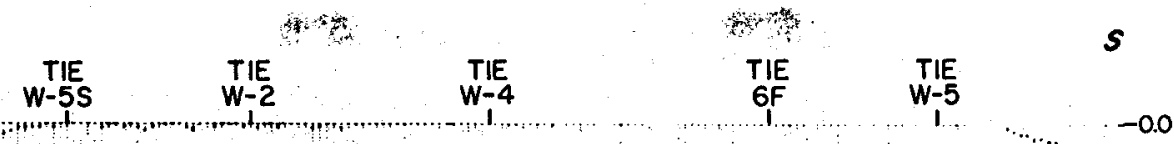

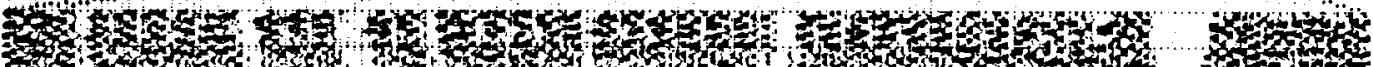
3.

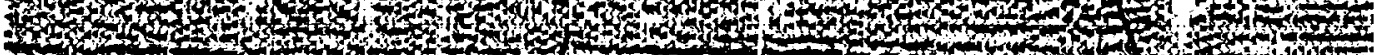

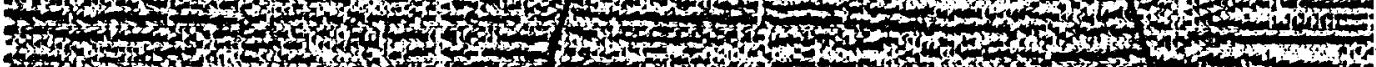

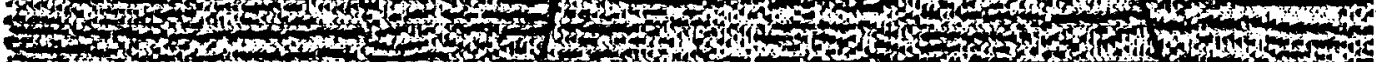

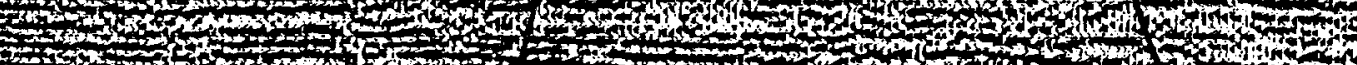

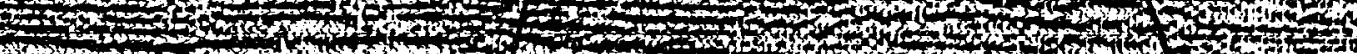

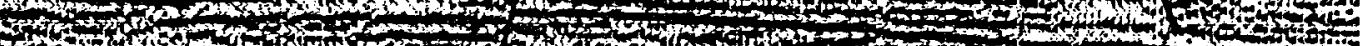

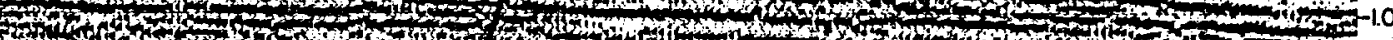

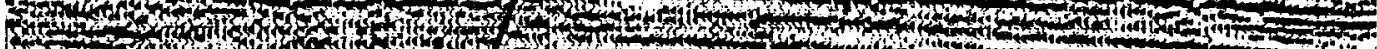

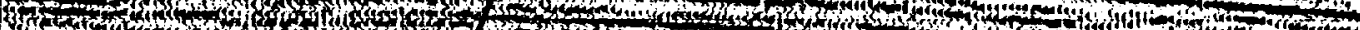
sulu 5.4. $0+20$ C

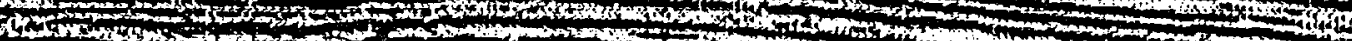

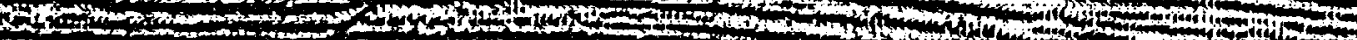

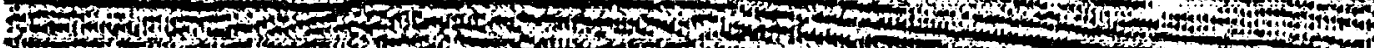
Ophom 27toky

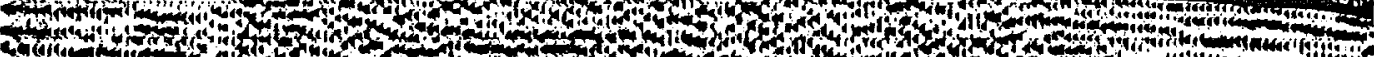

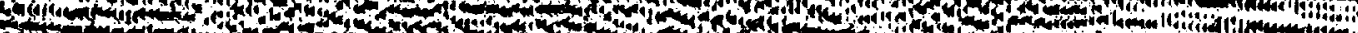
2.

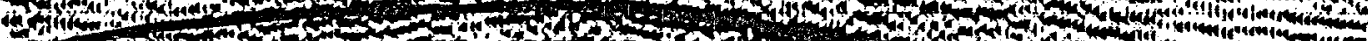
-

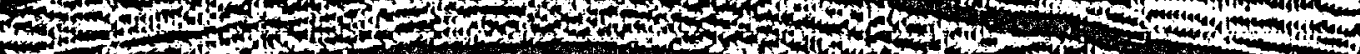

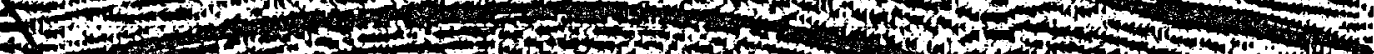

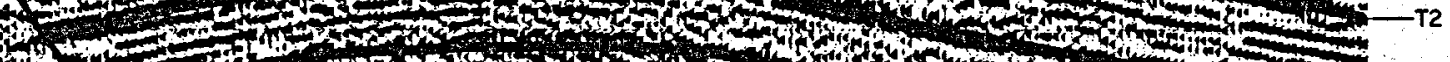

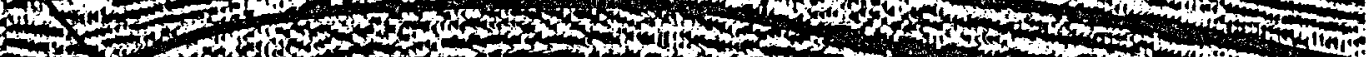

Thow

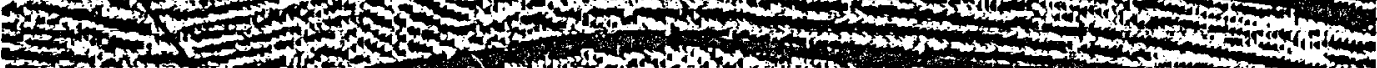

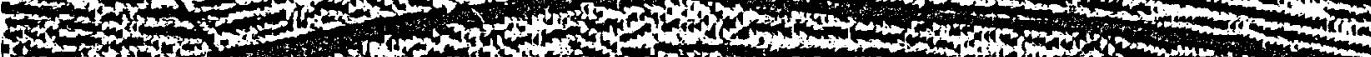

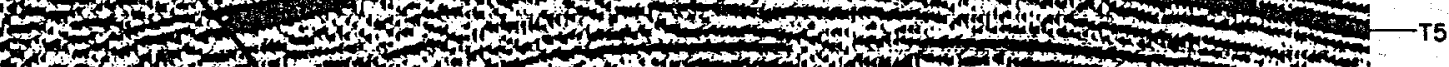

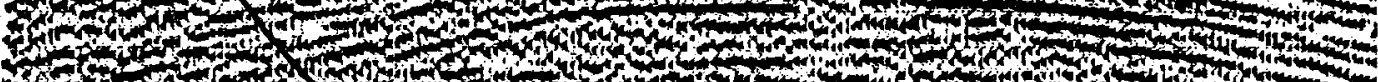

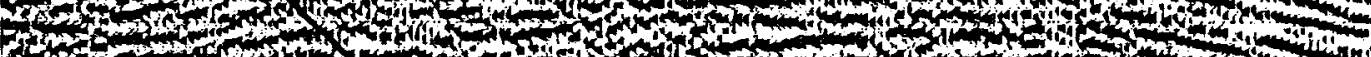

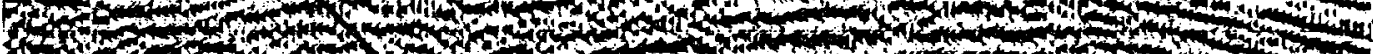
100 -

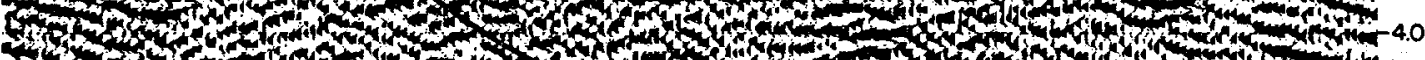

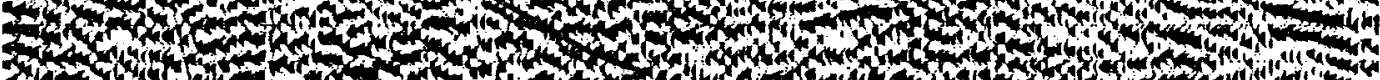

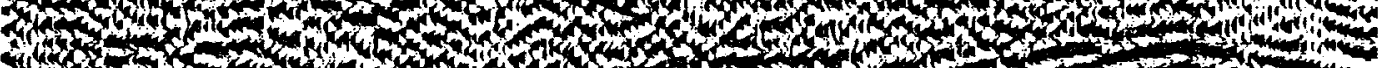

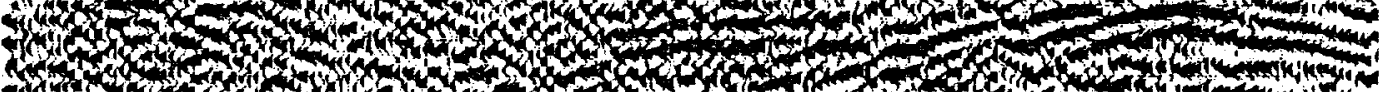

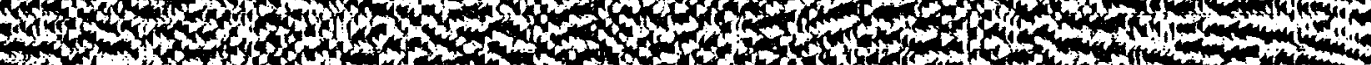

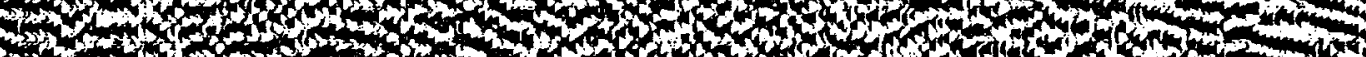

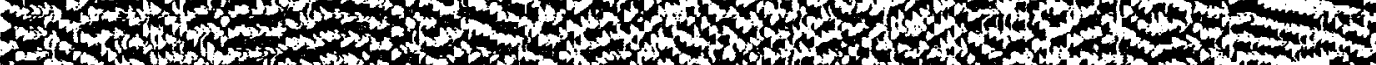

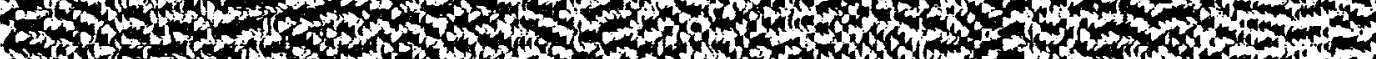

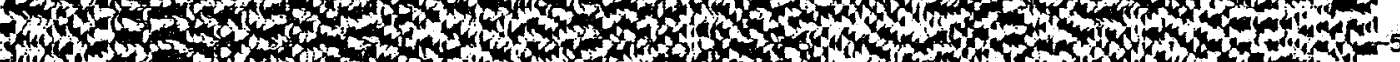

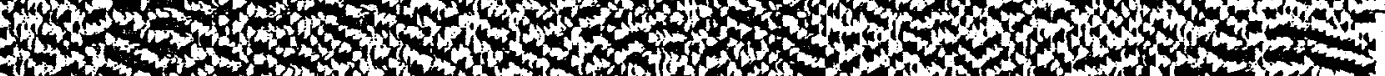
16.

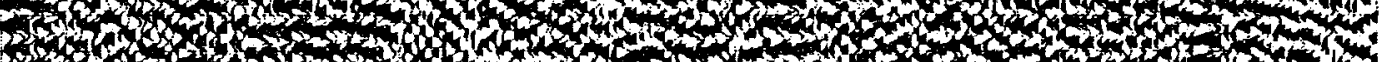
3340 of

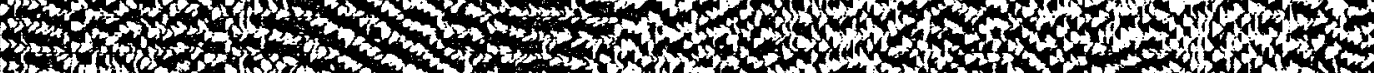

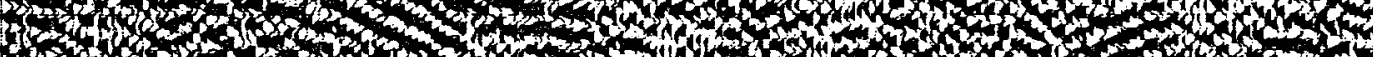

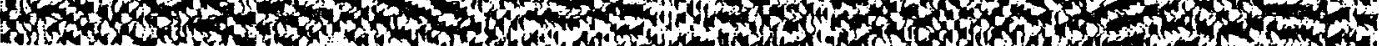

Figure 26. Western line $W-1$, as delivered. This line best shows the major down-tothe-basin growth fault near Danbury Dome. 


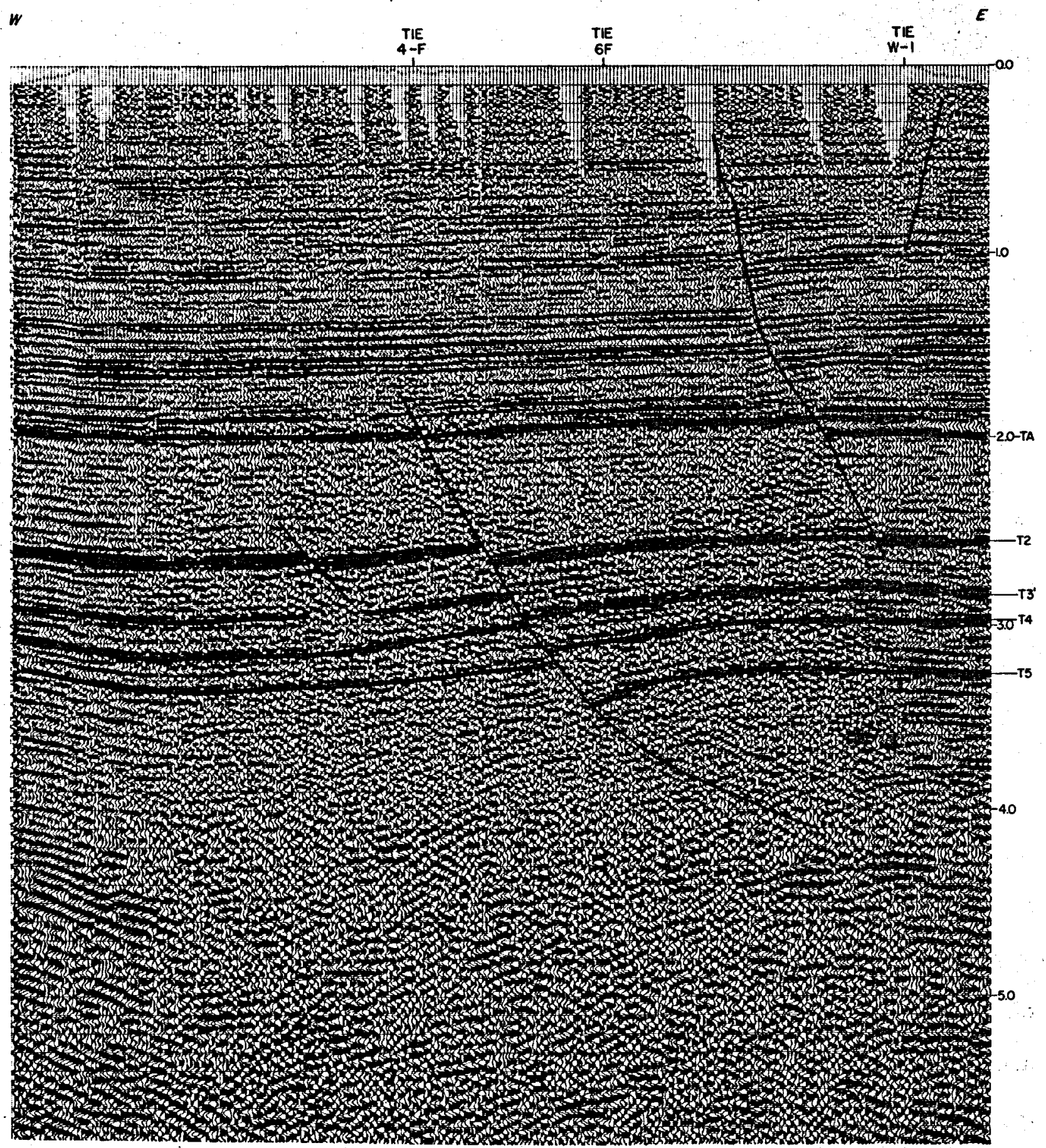

Figure 27. Western line $W-5$, as delivered, shows the difference in fault styles with depth. Deep structure is dominated by large down-to-the-basin growth faults. Shallow structure is dominated by radial crestal faults associated with Danbury Dome. These crestal faults die out with depth. 
Also seen on this line are two faults that cut the Miocene section but which die out downward before reaching the lower Frio. These are interpreted as radial faults from Danbury Dome that were formed in post-Frio time. Expansion of sections across these faults is slight.

\section{Velocity Distribution}

Knowledge of velocity distribution in three dimensions is essential for data processing. One objective of this study was to determine the geological controls on velocity in the study areas.

Velocity data are obtained in three ways: acoustic logging of wells, velocity surveys, and velocity analyses. The acoustic logging tool measures transit time and, hence, average velocity over a short distance (several feet). Average interval velocities and time-depth conversions can be obtained by integration. Acoustic logs are prone to systematic errors and tend to underestimate velocities; integrated acoustic logs are therefore prone to cumulative errors and thus are unreliable for time-depth conversion.

Velocity surveys are obtained by measuring down-hole arrival times from surface shots near a well, and by making appropriate geometric corrections. Errors are due primarily to difficulties in picking the first breaks consistently; this problem becomes more serious as the depth increases. Interval velocities are obtained essentially by discrete differentiation; any errors in measuring arrival times result in substantial anomalies in interval velocities. Nonetheless, velocity surveys are generally the most reliable source of time-depth conversions and average formation velocities.

Velocity analyses attempt to determine the optimum stacking velocities for multi-channel seismic reflection data, using a variety of displays to show peak amplitudes of the stacked signal as a function of stacking velocity and arrival time. 
Ideally, for flat-lying reflectors, the optimum stacking velocity is equal to the root mean square ( $\mathrm{rms}$ ) velocity. As with velocity surveys, obtaining interval velocities is essentially a process of differentiation, and time-depth conversions are obtained by reintegration. In practice, optimum stacking velocities are not a very precise estimator of rms velocities, and interpretation of velocity analyses is highly subjective. Consequently, interval velocities obtained by this method are generally only a crude estimator of true interval velocities.

\section{Interval Velocities}

As determined from velocity surveys (fig. 28), velocity distribution in the Pleasant Bayou area is controlled primarily by stratigraphy. In the Miocene section, interval velocities increase fairly steadily with depth, reaching a maximum near the base of the Miocene. High interval velocities in the lowest Miocene may be caused in part by "hard streaks," high-carbonate zones evidenced by high log resistivities (Flanigan, 1980). The very high velocity interval showing up in the geothermal test well at the base of the Miocene is probably due to an inconsistency between adjacent shots in picking the first breaks; the calculated interval velocity of $17,000 \mathrm{ft} / \mathrm{sec}$ is unreasonably high.

The top of the Anahuac is marked by a sharp velocity inversion; all velocity surveys show the Anahuac to be a low-velocity zone. Flanigan (1980) cites this as evidence of geopressure within the Anahuac, although, as previously discussed, the relationship between formation velocity and pressure is probably not as straightforward as he suggests.

Within the Frio section, interval velocities again increase fairly steadily, with the exception of the Phillips 非-M Houston well. This well penetrated a major growth fault and continued to considerable depth through pre-Frio shale. Consequently, the low-velocity zone encountered in the lowest part of this well is not representative of the Frio. 


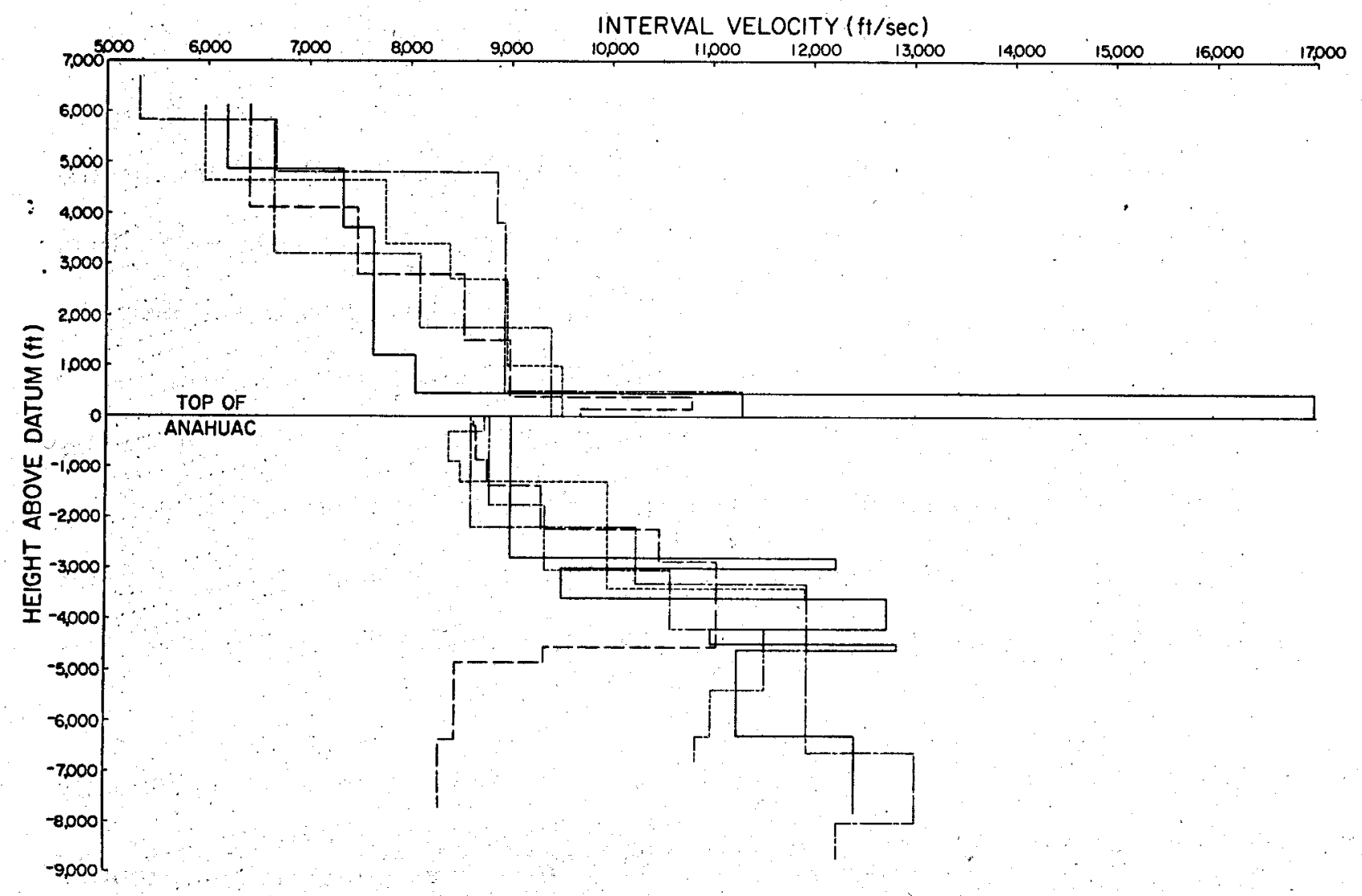

Figure 28. Interval velocities as determined from velocity surveys in five wells in Brazoria County (three shown in fig. 21). Datum is velocity inversion at top of the Anahuac. Extremely high velocity zone in Pleasant Bayou well is probably an artifact. 
Otherwise, the data do not indicate that a significant velocity inversion occurs consistently within the Frio as would be suggested by the pressure distribution (fig. 17). This further suggests that a simple general relationship between interval velocities and formation pressures does not exist. This observation casts doubt on the validity of using velocity inversions observed on velocity analyses to predict the top of geopressure ahead of the drill. This relationship is known to work in some areas of offshore Louisiana, but it does not appear to be universally applicable.

Two factors may invalidate the pressure-interval velocity relationship. First, there may be controls on shale velocities other than physical compaction, such as were suggested in the discussion on pressure distribution. In the Pleasant Bayou test well, the consolidation state of clays increases steadily from the Anahuac, to the normally pressured Frio, to the overpressured Frio (Milliken and others, 1981).

Second, a high percentage of well-cemented sandstones in the geopressured zone could overshadow any effect of low shale velocities, and no inversion of interval velocities would be apparent. This effect is expected to be particularly significant in geothermal prospect areas where a high sandstone perceritage in the geopressured zone is a prerequisite.

\section{Time-Depth Conversion}

In spite of major stratigraphically controlled velocity variations and substantial structural relief, lateral velocity variations do not appear to create serious problems for time-to-depth conversion (fig. 29), particularly when compared with the Cuero study area. Apparently, stratigraphically controlled velocity variations tend to cancel out when integrated to obtain the time-depth curves.

As a result, conversion to depth of all migrated sections is recommended if further structural analysis is to be undertaken. Not only is this a simple process when performed automatically, but it yields a more accurate picture of the structural geometry. 


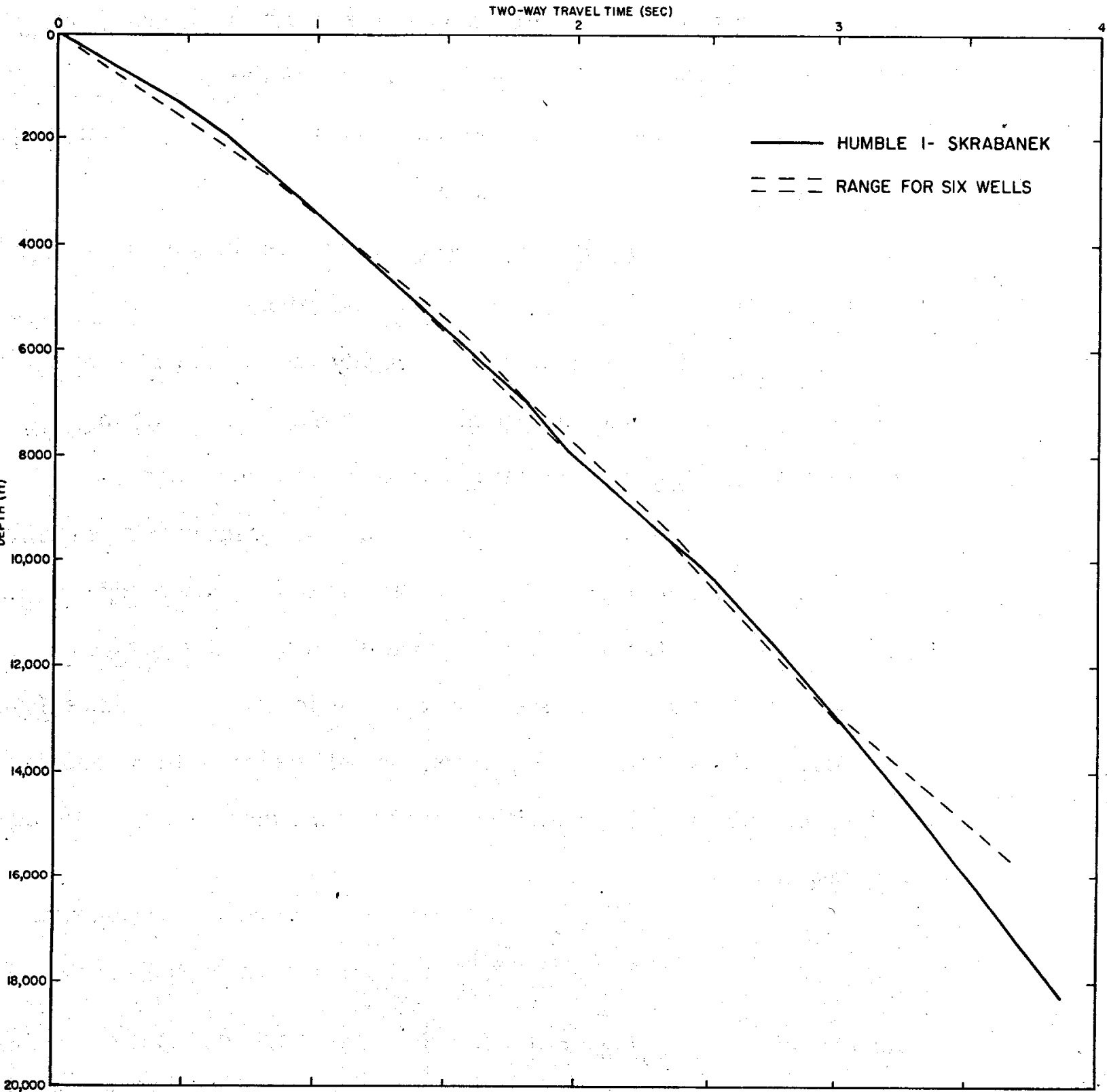

Figure 29. Range of time-depth curves obtained from six velocity surveys in Brazoria County. 


\section{BLESSING AREA}

\section{Stratigraphic and Paleogeographic Setting}

Sandstones containing potentially useful geopressure geothermal energy in the Blessing study area occur in the Anomalina bilateralis zone of the lower part of the Oligocene Frio Formation. The lower Frio represents the maximum progradation of sandy facies in this area during the Oligocene (table 6).

Both the Frio and the Anomalina bilateralis zone are informally defined stratigraphic units. Correlation markers B1-B6 (Weise and others, 1981) were picked on distinctive breaks in the log pattern; these are roughly assigned to foraminiferal zones based on several wells with paleontological data (table 6). Note that the top of Frio as used in this report; the Cibicides hazzardi marker is between B2 and B3.

The Blessing reservoirs are situated within the Greta-Carancahua strandplain system of the Frio (Galloway and others, in press), near the southwestern edge of the Houston delta system (fig. 2). The study area is located within a trend of contemporaneous down-to-the-south faults that were most active in early and middle Frio time. This trend also marks a rapid downdip change in lithofacies, both in sandstone percentage and log character implying deposition near the contemporaneous shelf edge (Winker and Edwards, in press).

\section{Operational Stratigraphy}

Detailed study of the Blessing area (fig. 30) began with the correlation of distinctive electric log markers. Where possible, these were chosen at the tops of major facies packages or major lithologic breaks. Stratigraphic units bounded by these markers were numbered sequentially from youngest to oldest (table 6) to simplify labeling of maps and sections. Log markers were transferred to nearby seismic 
Table 6. Characteristics of operational stratigraphic units in the Blessing area.

Unit Numbers

for Isopach Maps \&

Log Corre

Micropaleon

Structural Section

Log Correlation Micropaleo

Stratigraphic

$\therefore \quad \therefore \quad \therefore \quad$ a

Zone.

Unit

Lithology

Relative Velocity

ses

Overall

Transgressive/

Regressive

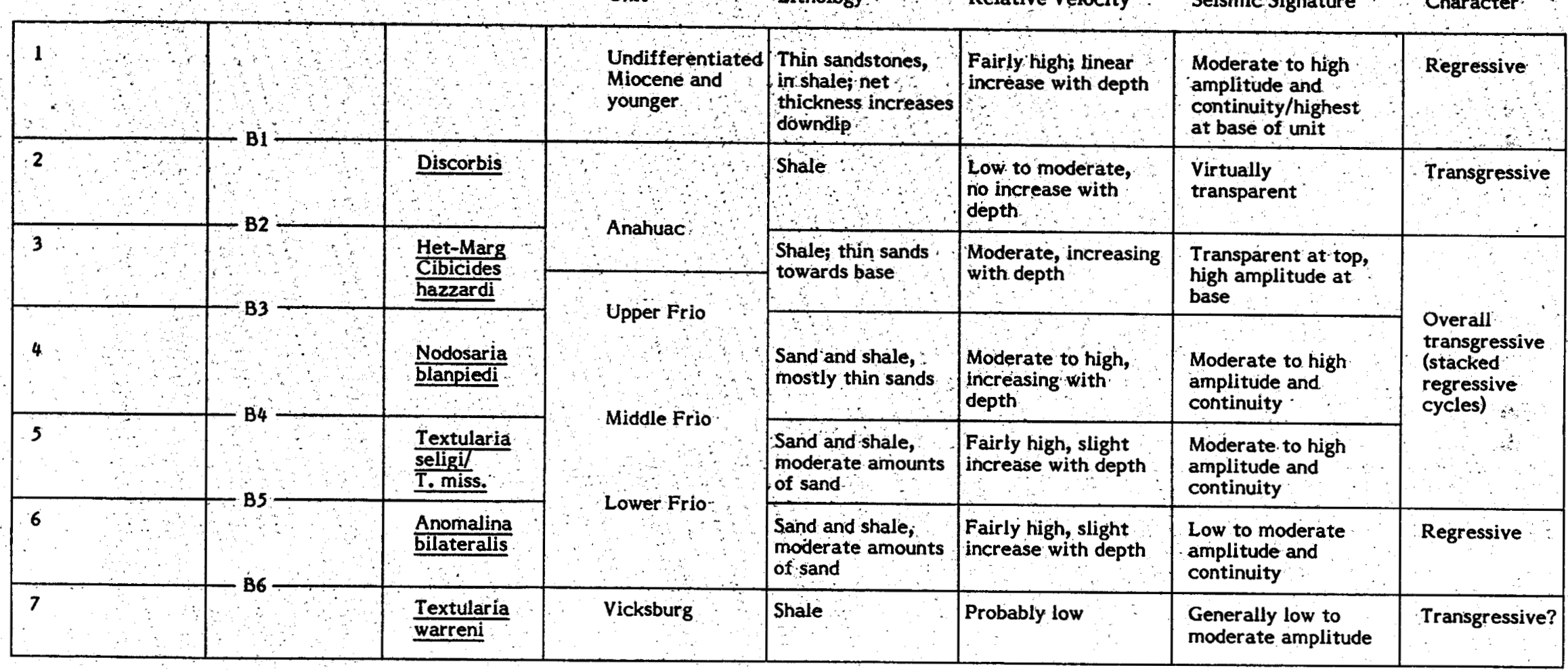




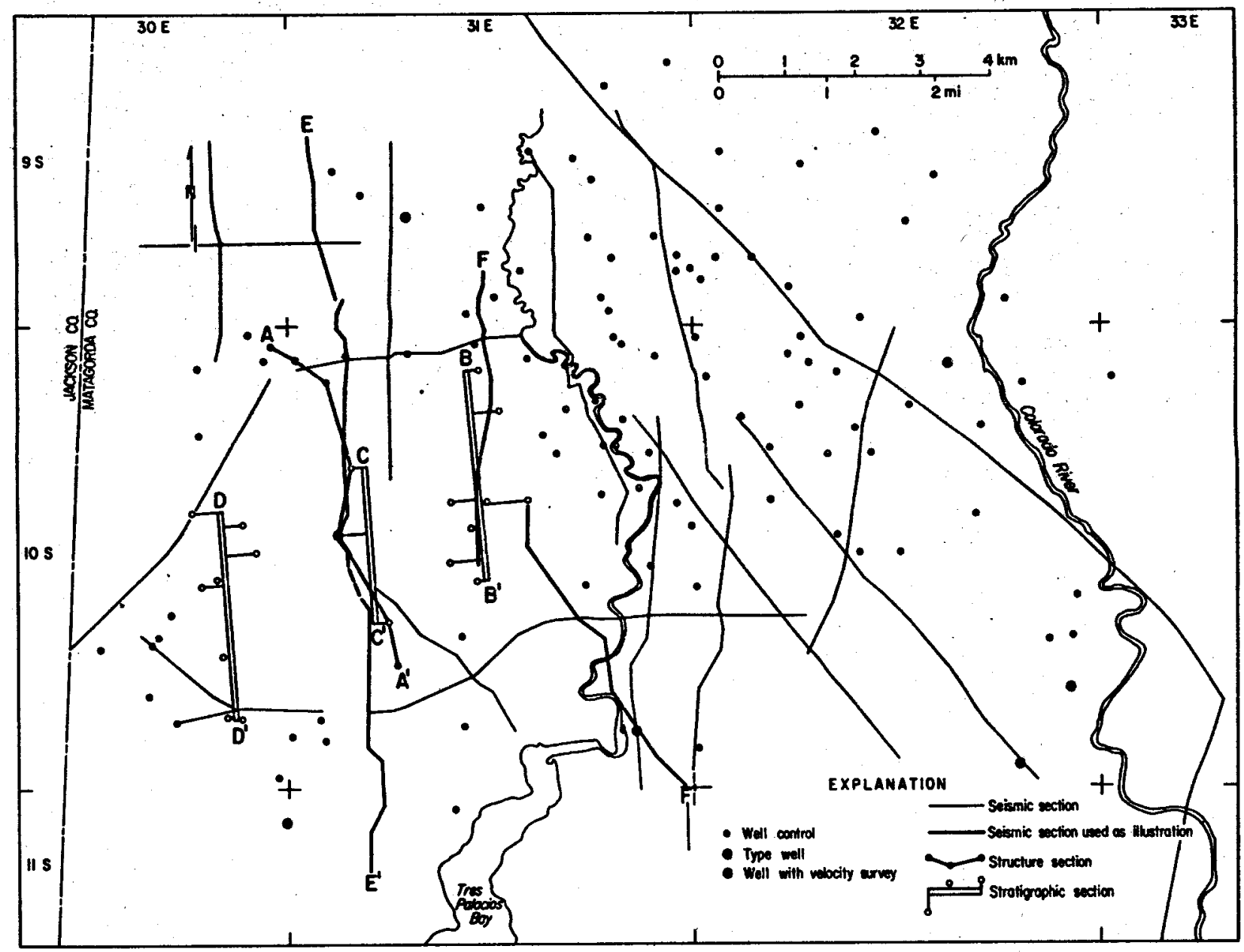

Figure 30. Base map showing locations of available deep well control, seismic sections, and velocity surveys in the Blessing study area. 
sections, and velocity survey data from five wells in the area were used for conversion from depth to time.

\section{Structural Setting}

The location of the Blessing area along the Frio growth-fault trend limits the potential size of Frio geothermal reservoirs. These growth faults are interpreted to result from large-scale basinward sliding of the continental slope, creating extension along the shelf margin. The area lies southwest of the Houston salt dome basin; salt in the Blessing area was thin, and no salt structures are present. Shale diapirism was, however, active in the area during Vicksburg and lower Frio time.

\section{Local Structure}

\section{Structural Style}

The structural style of the Blessing study area (figs. 5B, 31, and 32) is typical of the Frio trend in the middle Gulf Coast area. Characteristics of the Frio trend include highly sinuous growth faults of variable spacing (generally less than $1 \mathrm{mi}$ ), predominantly down-to-the-basin with thousands of feet of displacement, and growth ratios up to 10 with substantial rollover on the downthrown block. Displacements and growth ratios typically vary greatly along the major faults: Fault dips at the depths of interest are typically $45^{\circ}$ to $50^{\circ}$. Faults flatten slightly with depth, but the décollement has not been seen on seismic sections. Décollement must be considerably deeper than in the South Texas Vicksburg trend (fig. 5D), but the listric nature of these faults is evidenced by the substantial amount of rollover.

In the Blessing area, two major sets of growth faults cut the lower Frio (fig. 32). The updip set consists of several faults enclosing lesser fault compartments. This set bounds the Blessing block on the north, separating it from Tidehaven and Francitas 


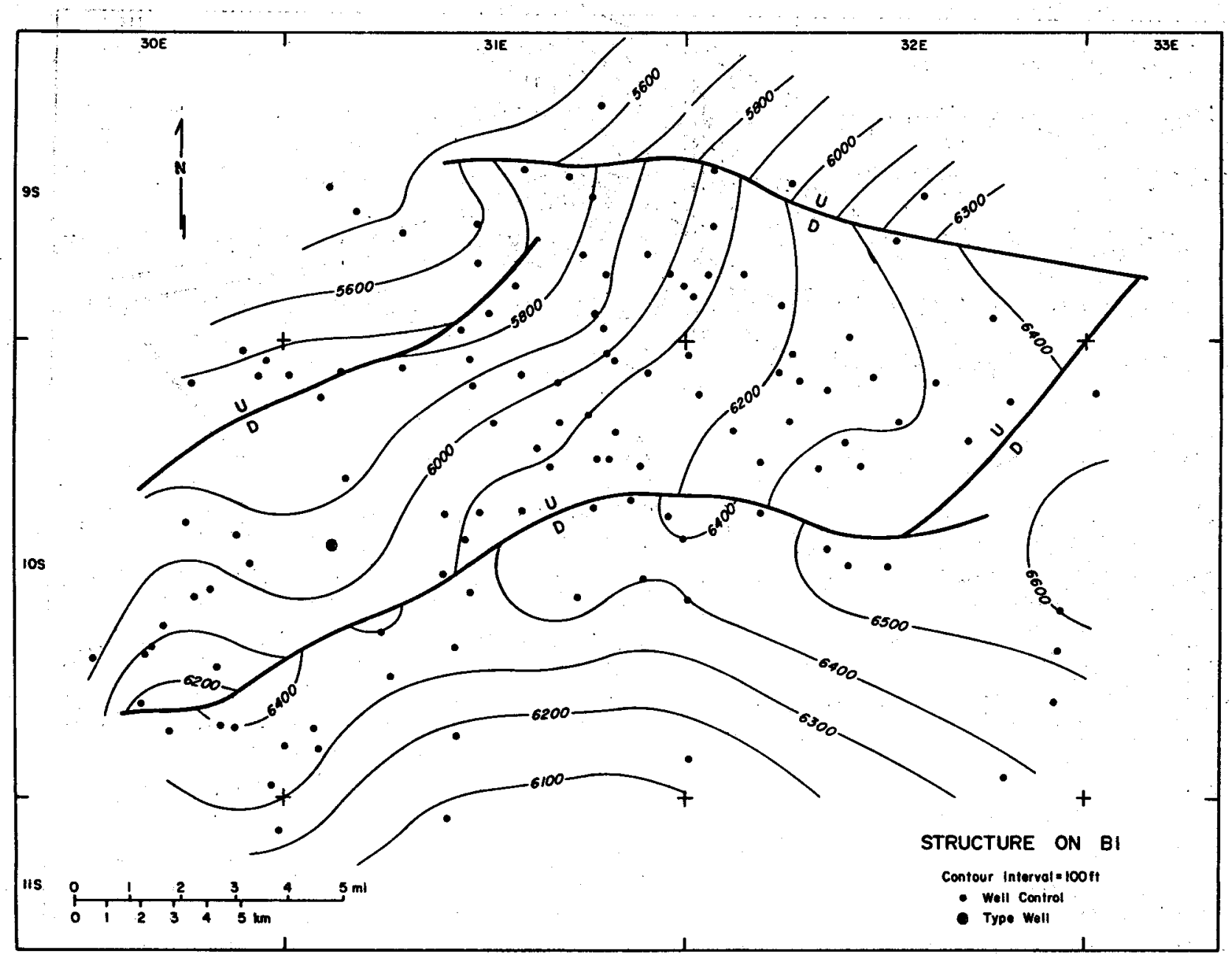

Figure 31. Structure contour map of B1 correlation marker (top of Anahuac). 


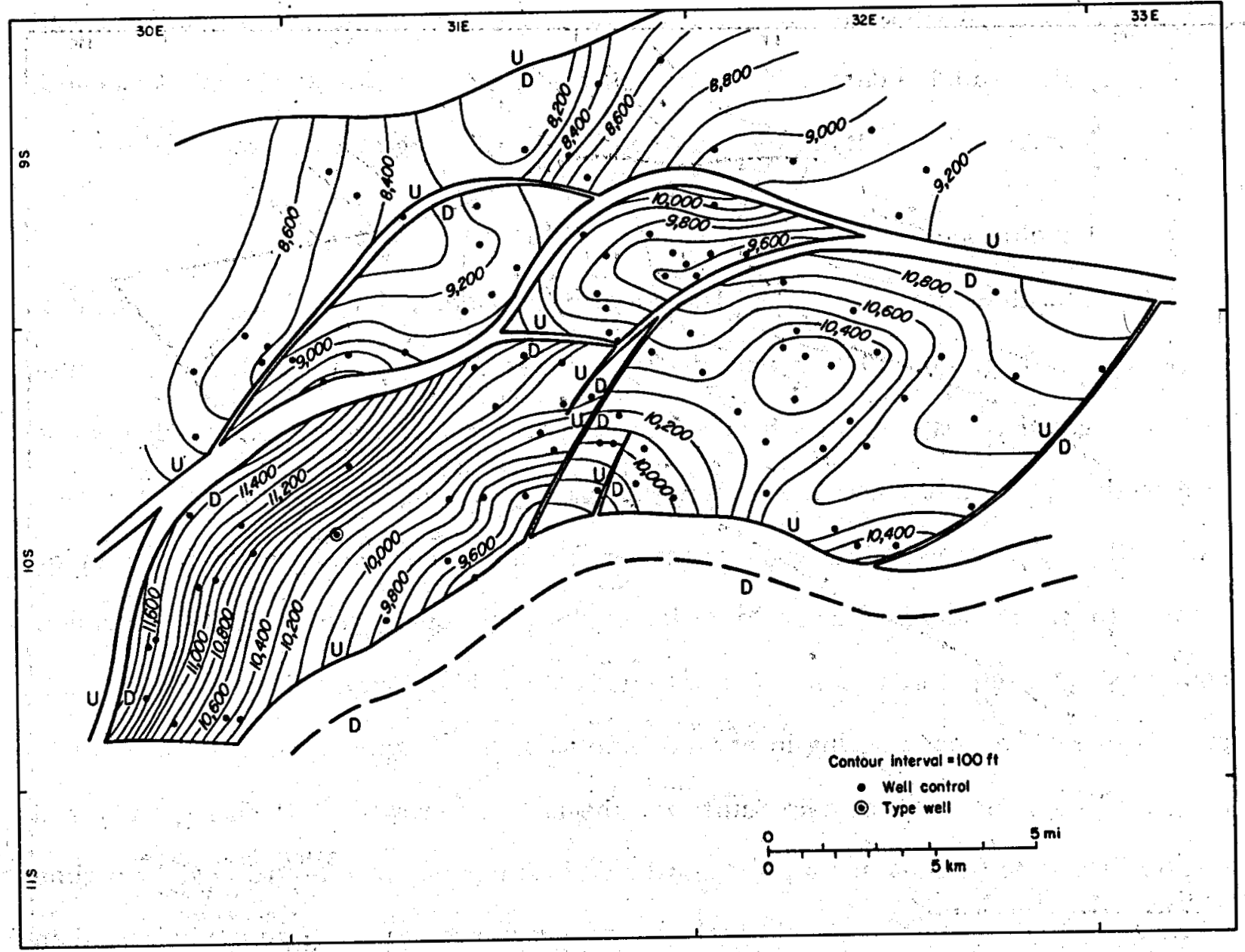

Figure 32. Structure contour map of B5 correlation marker (top of Anomalina bilateralis zone). 
fields. The downdip fault appears to consist of a single large growth fault, bounding the Blessing block on the south and separating it from the Trull field. Both sets of faults have a subdued expression in the Miocene (fig. 31 ).

In addition to these faults, small cross faults cut across the Blessing fault block. A zone of small faults bisects the Blessing block east of the Blessing field and the area where geopressured sandstones are best developed. The nature of this zone is not well defined by the available data, although it appears to break continuity in unit 6 (sub-B5; fig. 32). A small cross fault is inferred to bound the Blessing block on the southwest.

\section{Structural Evolution}

Structural evolution of the Blessing area was studied by means of sequential isopach maps (fig. 33). In this area distinct stages of structural evolution have not been recognized. Instead, structural evolution was characterized by a steady decline in growth fault activity and late southward tilting. During earliest Frio time (interval 6), the updip growth fault underwent large-scale movement, growth ratios being from 4 to 8 , and large rotation into the fault. This updip growth-fault movement continued through unit 5 time and into unit 4 (middle Frio). The downdip fault probably began to move during interval 6 time as well, but the data are inadequate to define this stage. The downdip fault was the primary growth fault during early and middle Frio time (units 4 and 5), and continued into unit 3. In late- to post-Frio time (units 1-3), fault activity was relatively minor, growth ratios being generally less than 1.2.

The Blessing fault block underwent large-scale rotation and thickening of section into the updip growth fault from unit 6 through unit 4 time. This activity has resulted in predominantly landward dips in these units, and in sealing of the sands in these units by pre-Frio slope shales to the north and northwest. 

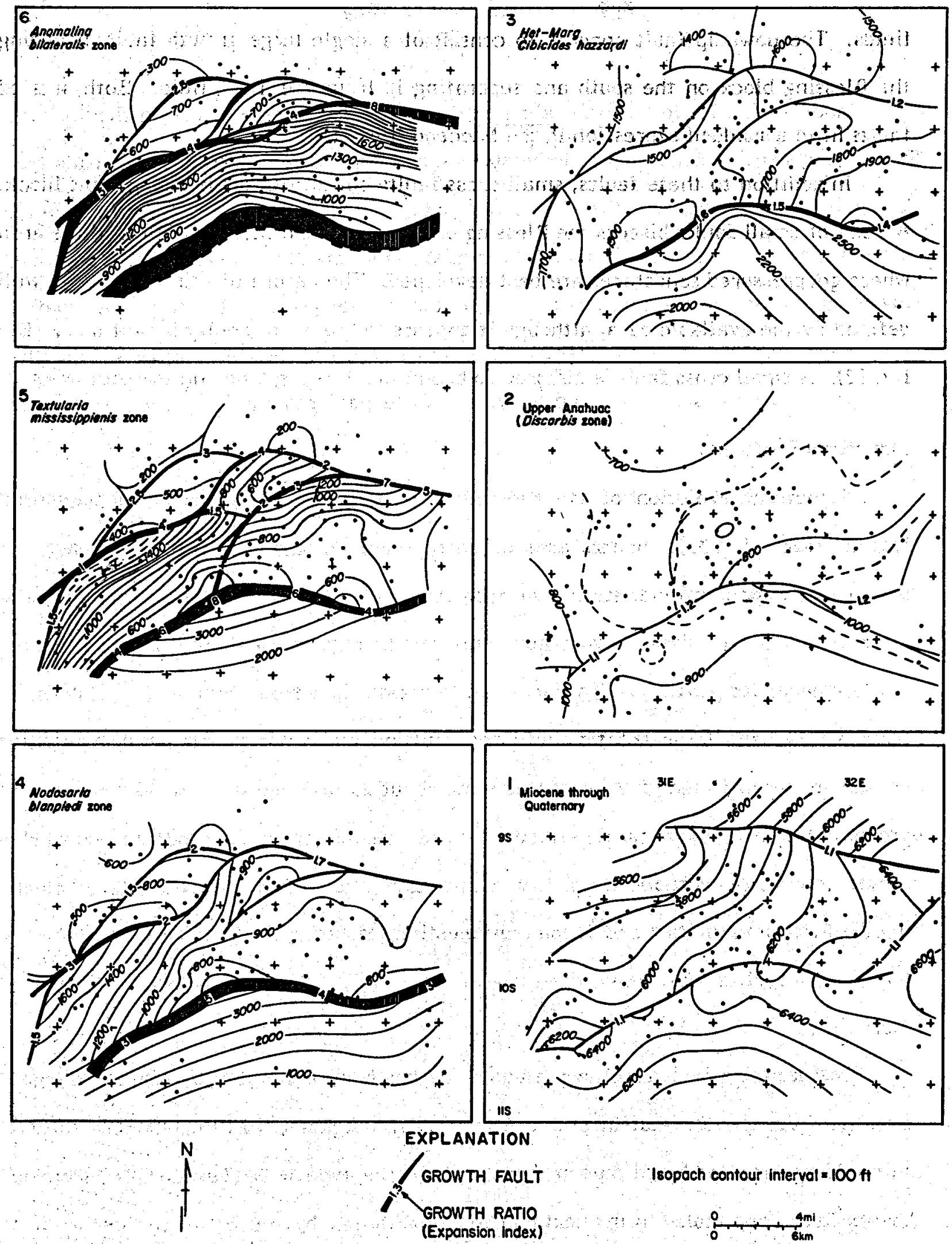

Isopoch contour interval $=100 \mathrm{ft}$

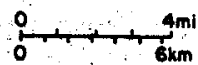

Figure 33. Sequential isopach maps illustrating structural evolution of the Blessing study area. Distortion of grid is caused by removal of horizontal component of postdepositional faulting. Early large-scale growth faulting and rollover ended by late Frio time. 
Sandstone facies in the Anomalina bilateralis zone were classified on the basis of SP patterns and on continuity of individual sandstanes inthree facies, representing two different environments and the effect of growth faulting, were recognized (table 7). The first facies represents barrier or strandplain sands stacked one atop andertivent The first facies represents barrier or strandplain sands stacked one atop another by the slower rates of subsidence northwest of the updip growth fault. The spatial relationships of the other two facies are summarized for the Blessing faultiblock by stratigraphic sections (fig. 34) and by maps of log patterns for individual sandstones (figs. 35 and 36 ).

For reservoir evaluation, two kinds of facies variability that can be deduced from log patterns are considered significant: maximum thickness of sandstone, and upward-fining (or blocky) versus upward-coarsening vertical trend. Most of the sands in the Blessing area exhibit upward-coarsening, or blocky, vertical trends, representing prograding barrier settings. The areas of thickest sand free from shale breaks are strike aligned (fig. 16), as is typical of bars or strandplain sands. Permeabilities of the sand bodies are not 'high (sidewall cores show about $25 \mathrm{md}$ ), but do show some increase upward within the individual sand bodies. The area of optimum sandstone is fairly extensive and is favorably aligned with the elongation of the Blessing fault block (fig. 16), leading to moderately high reserve estimates.

\section{Pressure Distribution}

Pressure distribution in the Blessing area has been estimated by three different criteria: bottom-hole shut-in pressures (fig. 37), weights of drilling mud used, and shale resistivity plots. The mud weights used in the type well (Texaco 1 16 Thomas) indicate a deeper top of geopressure than is estimated by the other two techniques (9,800 ft vs. about $8,500 \mathrm{ft}$, fig. 38). Relatively low-weight muds (11.8 lb/gal) were 
Table 7. Electric-log facies in the Anomalina bilateralis zone (unit 6), lower Frio, Blessing area.

Environmental

Interpretation

Stacked barrier/ strandplain sands

Barrier barl

strandplain
Characteristics

Thin section; high percent sand in blocky patterns, individual sands not correlatable
Geographic

Distribution
Northwest of block of interest
Blocky SP sand, largely in upward-coarsening sequences with sharp tops; thin shale breaks appear in areas of rapid subsidence

\section{Shelf/slope}

Shale, occasional thin sands
In block of interest; forming strike-elongate sand bodies
In downdip block, and separating sands in block of interest 

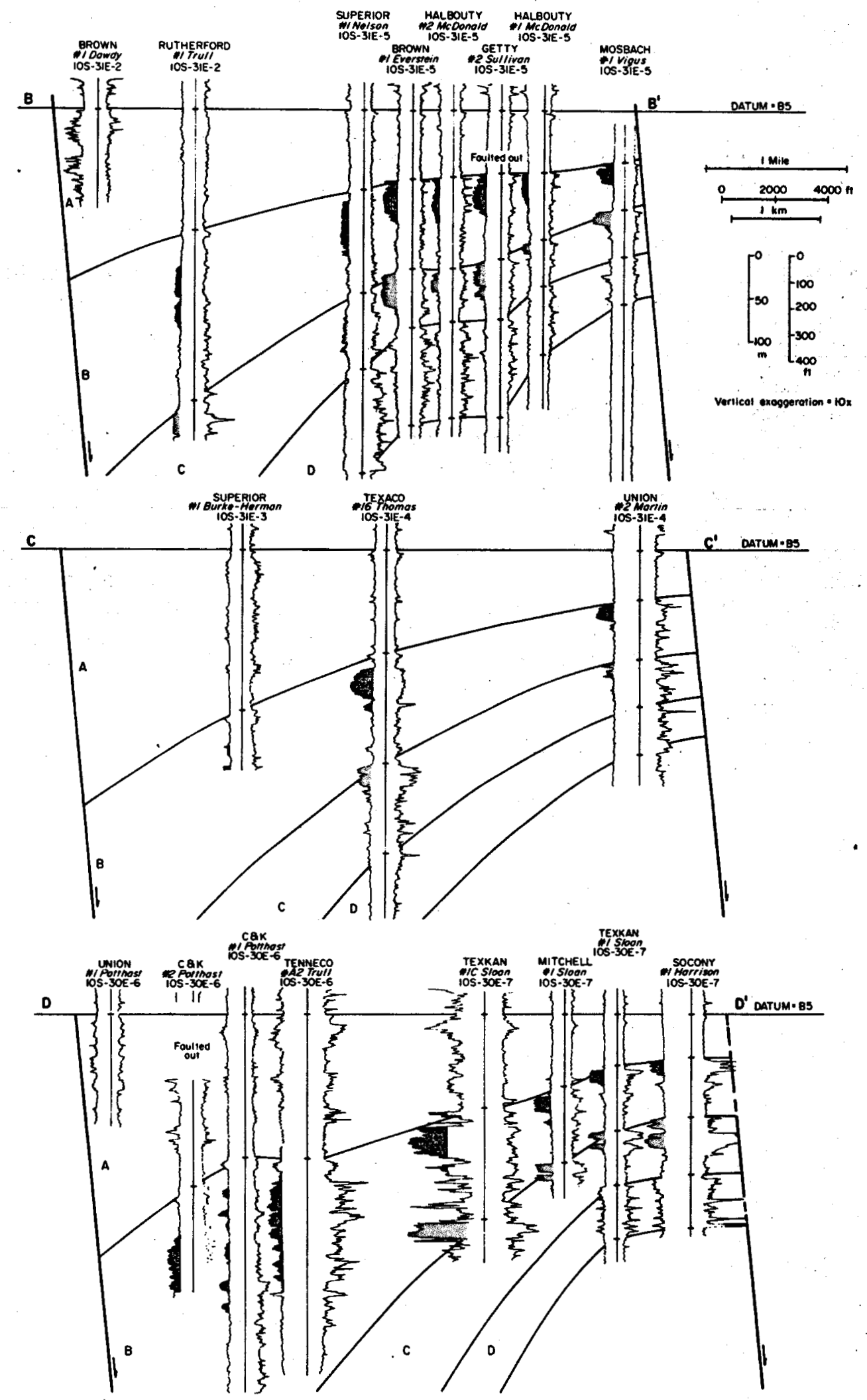

Figure 34. Stratigraphic dip sections of lower Frio (Anomalina bilateralis zone) within the prospective fault block, showing changes in sand character in the northern growth fault. 


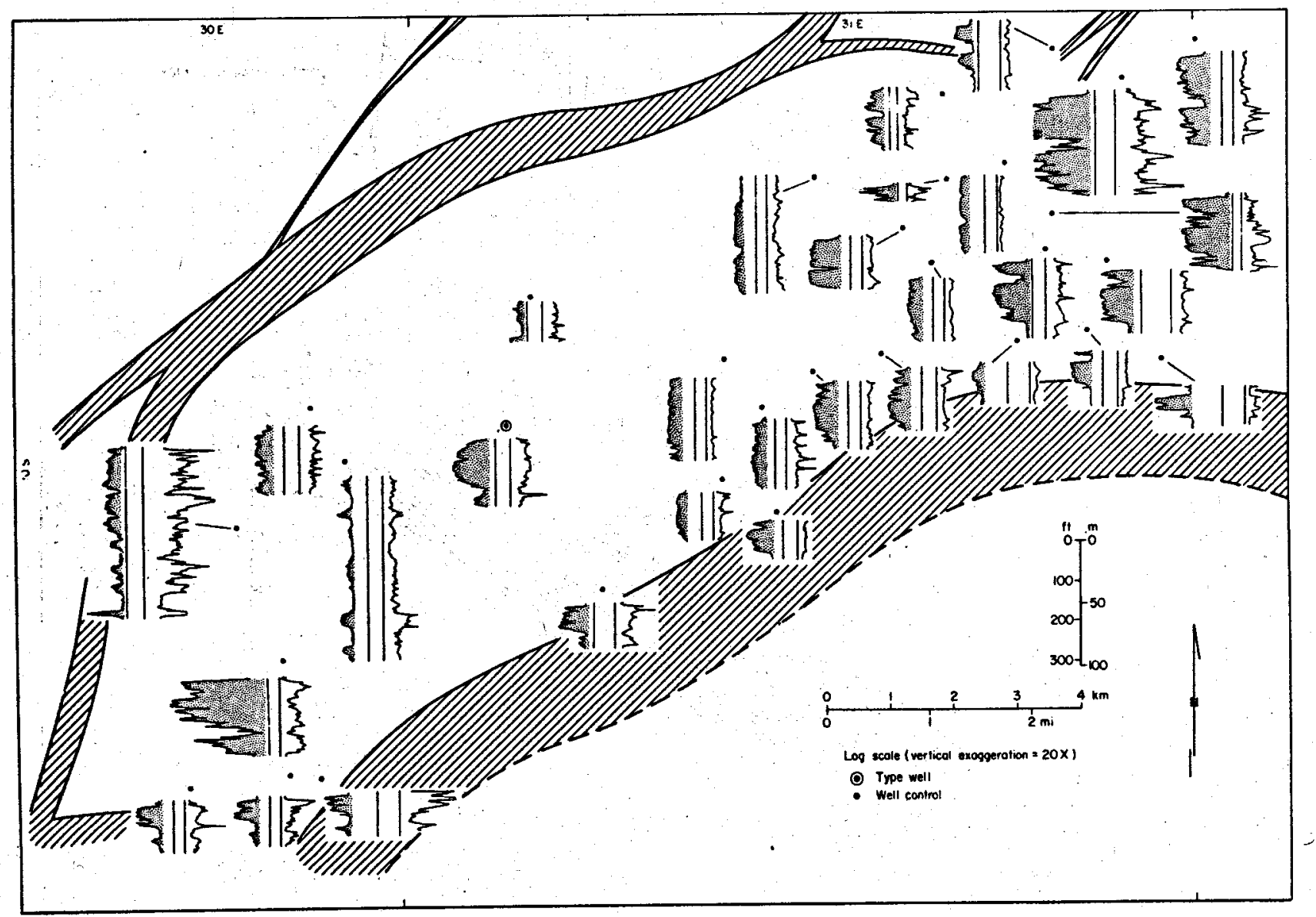

Figure 35. Log-pattern map of 'B' sand, lower Frio. 


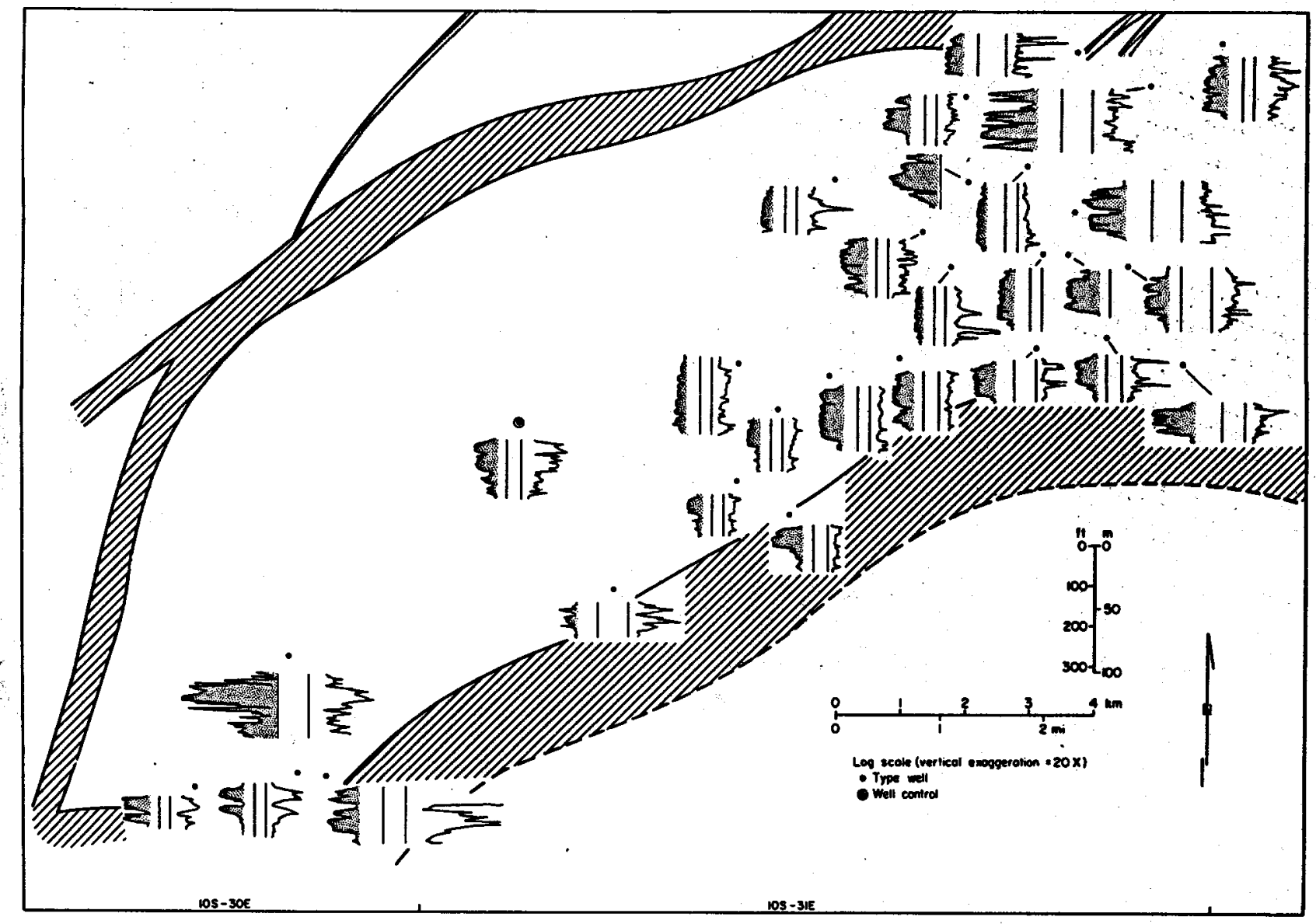

Figure 36. Log-pattern map of ' $C$ ' sand, lower Frio. 


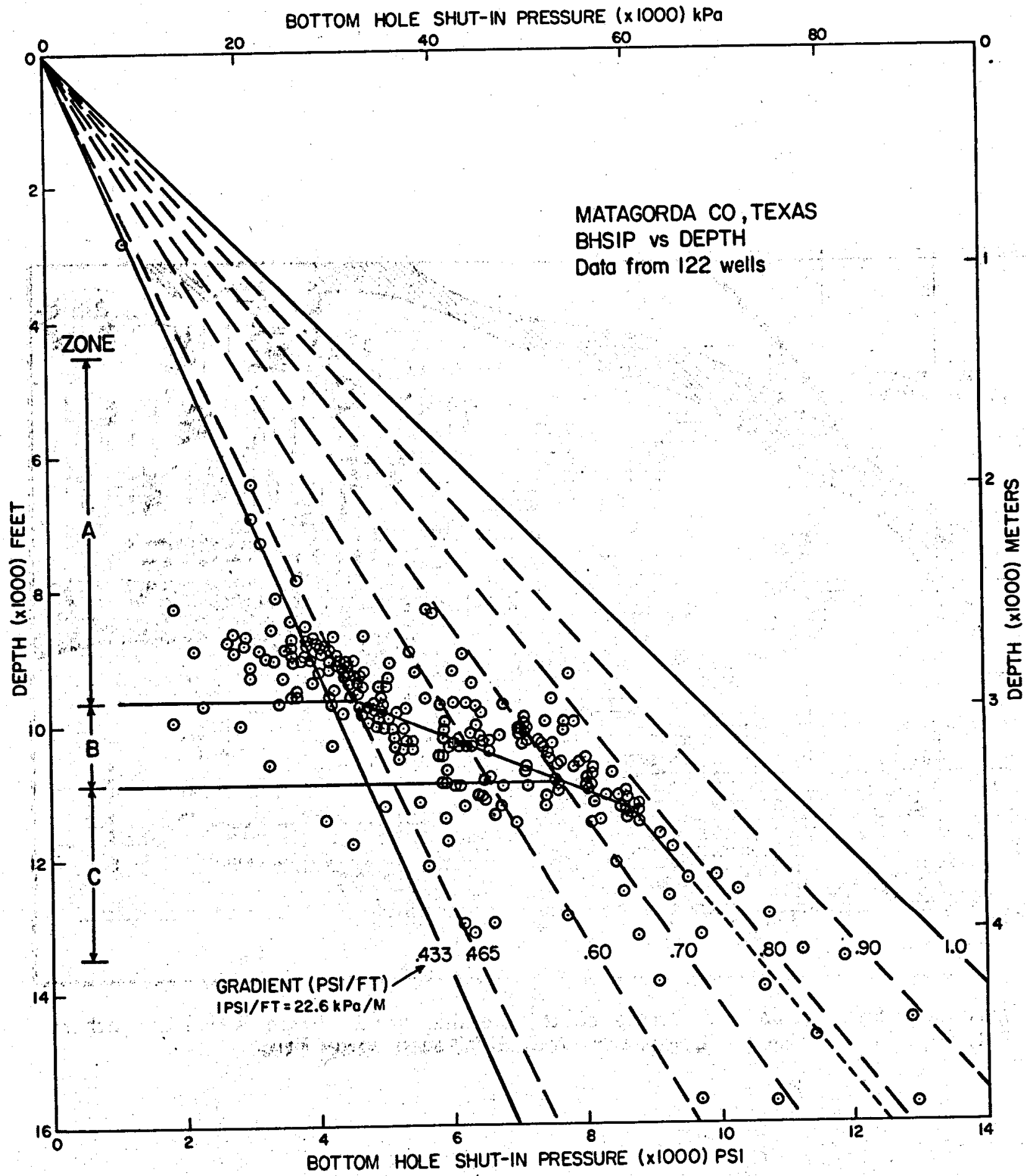

Figure 37. Static bottom-hole pressures versus depth for Matagorda County wells. From Weise and others (1981). 


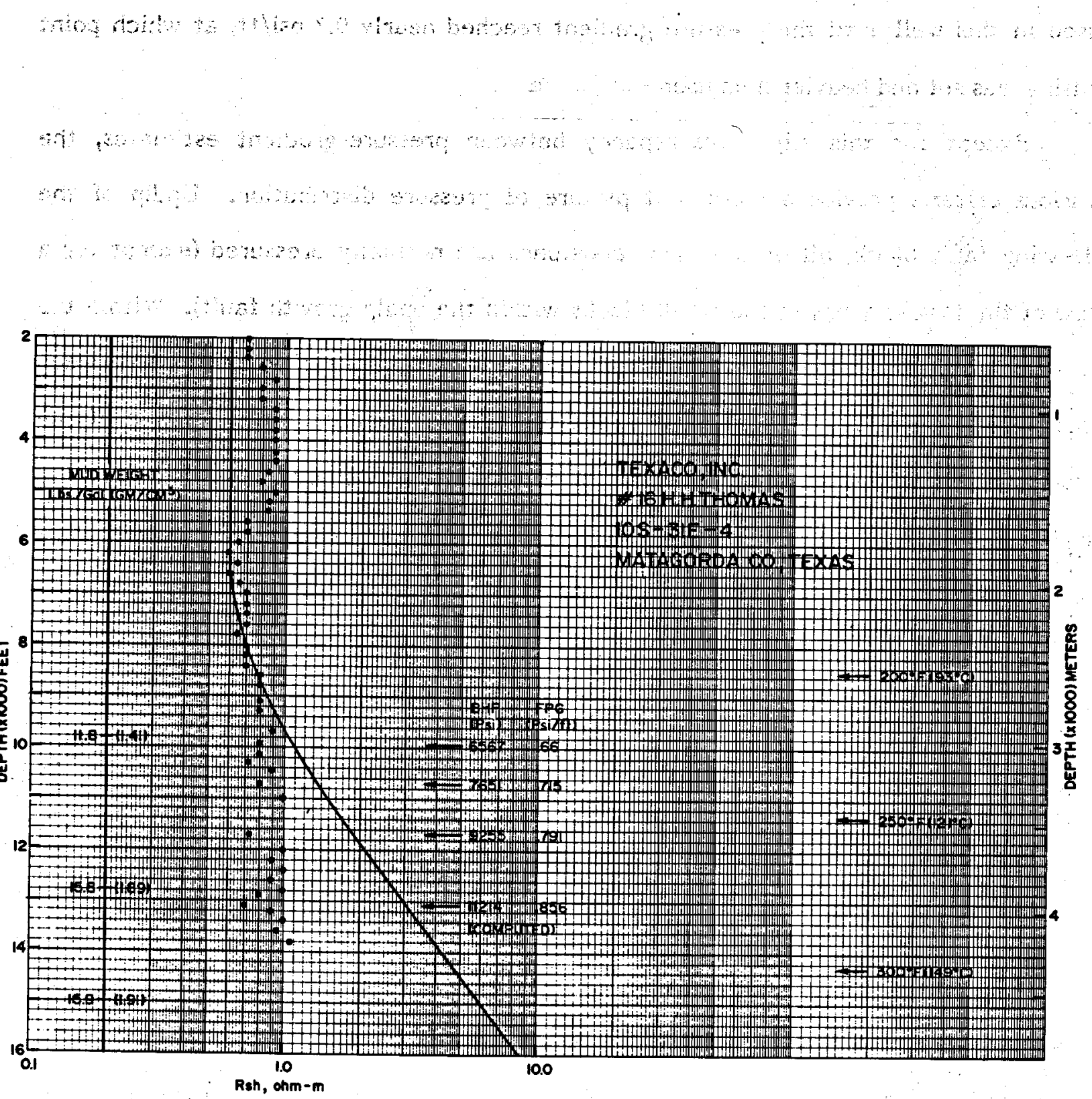

Figure 38. Shale resistivity versus depth, Blessing area. From Weise and others (1981). 
used in this well until the pressure gradient reached nearly $0.7 \mathrm{psi} / \mathrm{ft}$, at which point casing was set and heavier mud used.

Except for this slight discrepancy between pressure-gradient estimates, the various criteria provide a consistent picture of pressure distribution. Updip of the Blessing fault block, all of the Frio sandstones are normally pressured (except for a few of the lowest sands in the small blocks within the updip growth fault). Within the reservoir block, overpressure is first encountered within the Frio section, between markers B3 and B4, with a transition zone of several hundred feet. Downdip of the reservoir fault block, nearly all the Frio is overpressured. As noted elsewhere, isograd surfaces generally follow bedding planes within the fault blocks, although this correspondence is not necessarily exact.

\section{Seismic Studies}

Structural and stratigraphic interpretation of the Blessing area was enhanced by $132 \mathrm{mi}$ of proprietary seismic data. The lines acquired were shot between 1957 and 1973 (table 8), and employed a great variety of shooting parameters and processing techniques. Many of the critical lines passing through the area of interest are singlefold lines, which are not suited for stratigraphic work. In contrast to the Pleasant Bayou area, strong multiples were not a serious problem in the multifold Blessing lines.

The location of seismic lines is shown in figure 30. Most of them are dip lines, but a few cross more than two major faults. A complete picture of the reservoir block can be obtained only by piecing together different lines, commonly from different companies.

The Blessing seismic data was not reprocessed. The lack of a serious multiple problem and the relative simplicity of the structure have made "as received" copies adequate for interpreting the basic structure. The simple velocity structure of the 
Table 8. Seismic lines acquired for evaluation of the Blessing area.

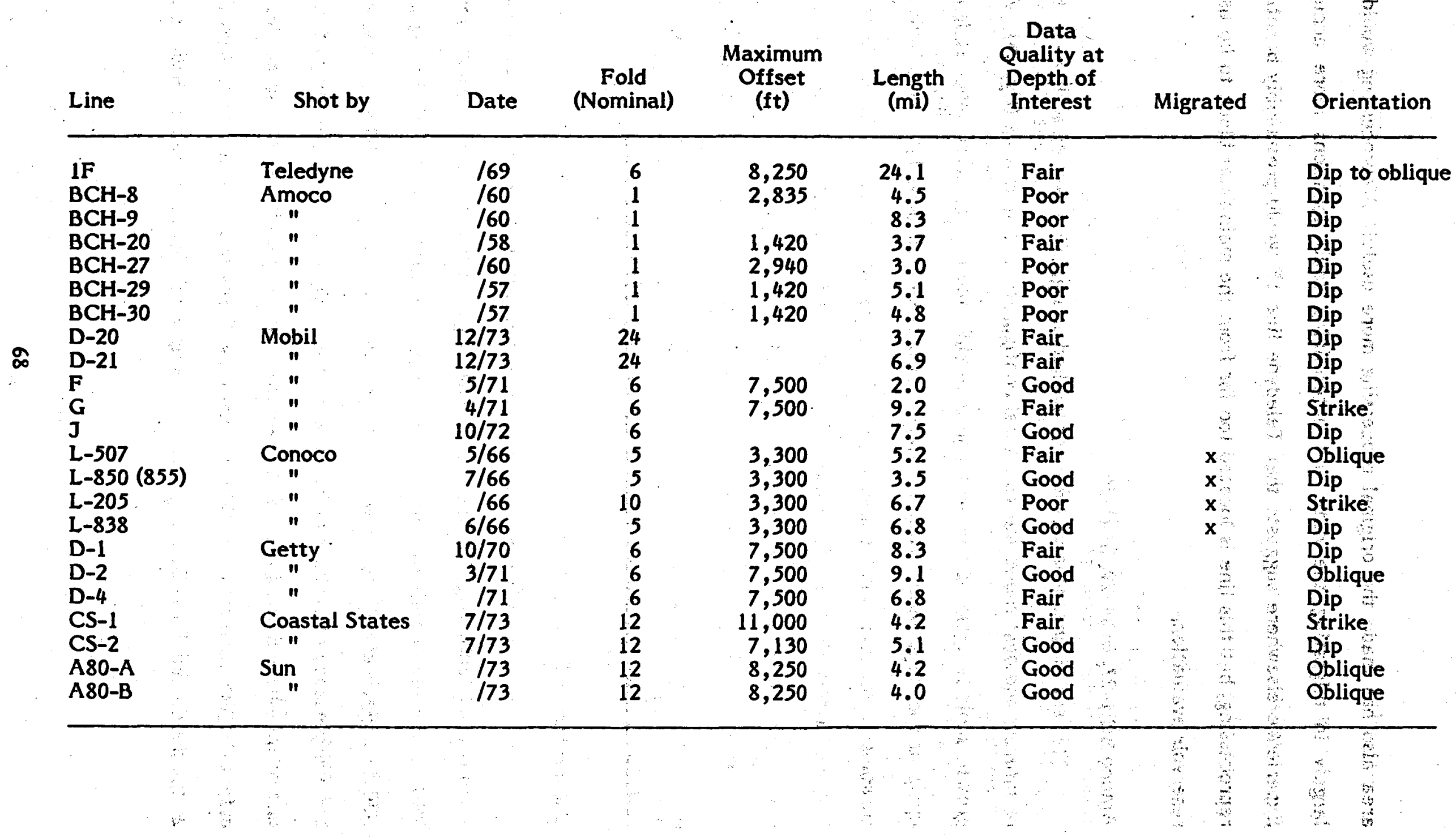


area also has made the original processing more useful. Reprocessing would assist largely in migrating the data and determining fault locations more accurately. Experience elsewhere suggests that Teledyne line IF would presumably benefit from reprocessing, but this line is located too far from the main fault block to be useful in reservoir evaluation.

Amoco BCH-27, BCH-29, BCH-30

This set of lines (the western set marked on fig. 30) passes directly over the area of interest and best shows the structural configuration of that area (fig. 39). A large growth fault is updip of the area and a smaller fault block with minor rollover lies updip of the large fault. Another large fault, is located downdip. This fault caused substantial rollover that extends into strata younger than the main fault block. Rollover within the main fault block (figs. 34 and 39) has created a thin area in the Frio at the southern edge of the block (south of the type well).

Data quality on these lines is good for single-fold data, although little detailed information on the stratigraphy and reflection character can be deduced. Sub-B5

reflectors, however, are prominent in the Blessing and Trull blocks.

\section{Coastal States CS-2; Mobil F}

This set of lines (fig. 40) runs north-south and is located just west of the zone of small normal faults (fig. 30, line F-F'). The large updip and downdip growth faults, as well as the broad rollover and generally landward dip of strata can be seen. Data quality is good enough to show the varying reflector continuity through the section, and the presence of strong sub-B5 reflectors is evident. Poor data quality at the north end of the Mobil F line (updip of the southern major growth fault) may be due to the effects of the zone of minor faulting mentioned previously. The thin area in the Frio at the south end of the Blessing block shows up well. No indication of shale diapirism 


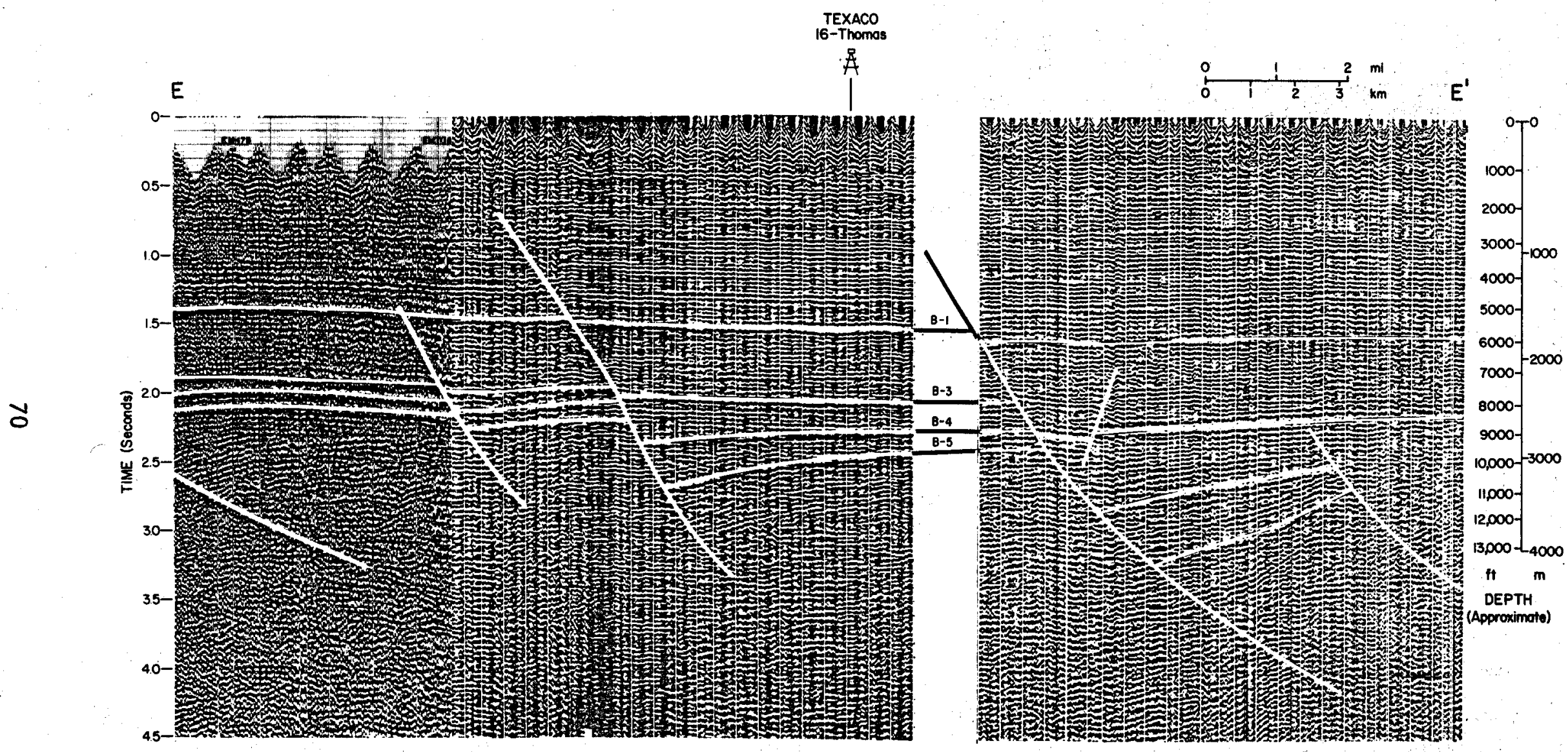

Figure 39. Seismic dip sections $\mathrm{BCH}-27, \mathrm{BCH}-29$, and $\mathrm{BCH}-30$. Location shown on figure 30. 


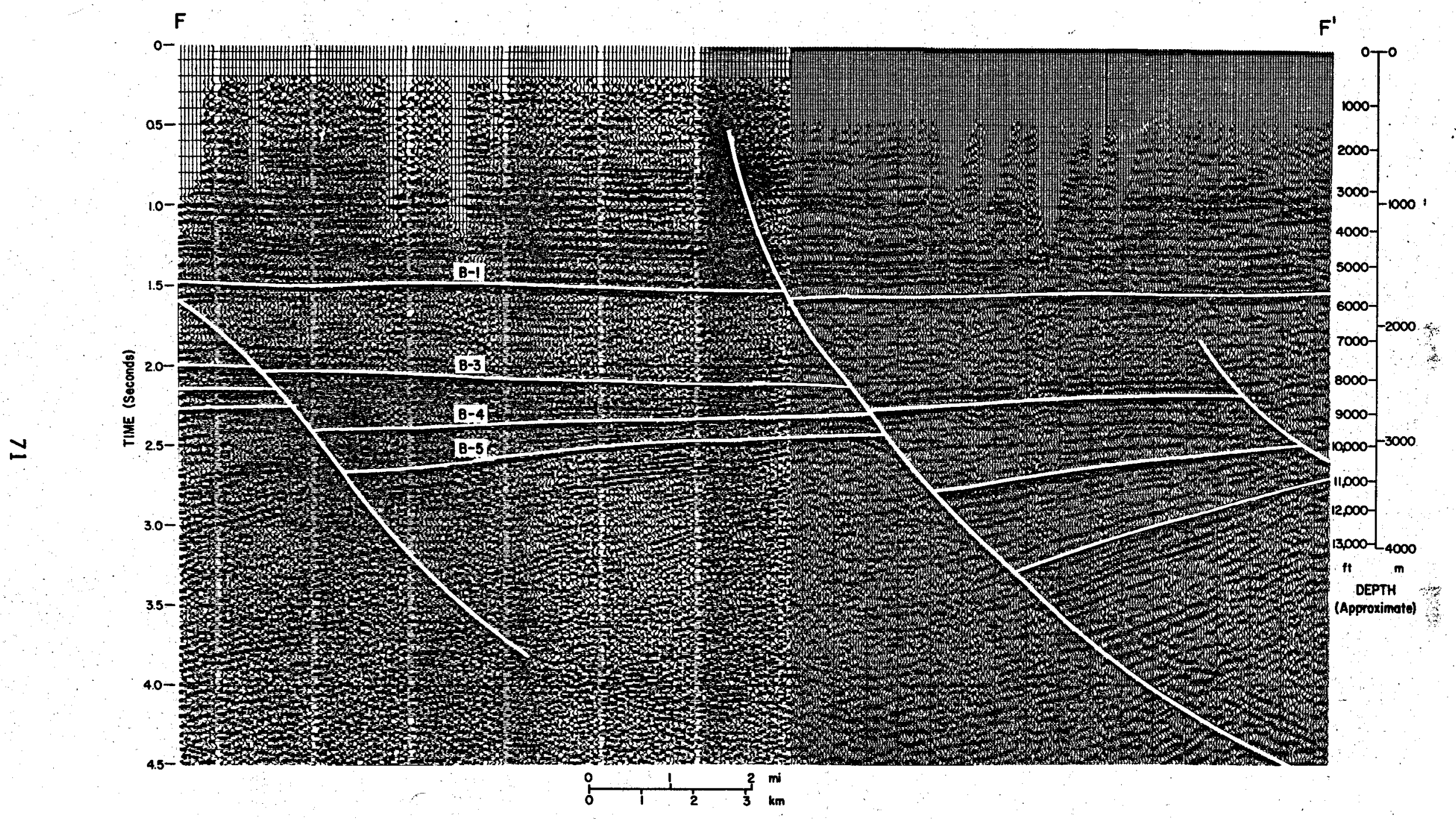

Figure 40. Seismic dip sections CS-2 and F. Location shown on figure 30. 
can be detected on this or other available seismic lines that cross the Blessing block; however, in the updip block, sharply landward-dipping reflectors suggest possible late Vicksburg diapirism.

\section{Velocity Distribution}

\section{Interval Velocities}

As determined from six velocity surveys in the area, velocity distribution is controlled primarily by stratigraphy (fig. 41). In the Miocene section above the Anahuac, interval velocities increase steadily with depth, reaching a maximum of about $8,800 \mathrm{ft} / \mathrm{sec}$ near the base of the Miocene. The top of the Anahuac is marked by a velocity inversion in four of the six surveys, but this inversion is not as pronounced as that at Pleasant Bayou. As discussed in the Pleasant Bayou section, this inversion is probably not a marker of geopressure in the Anahuac. Within the Frio, velocities vary widely, from $8,000 \mathrm{ft} / \mathrm{sec}$ to over $10,000 \mathrm{ft} / \mathrm{sec}$; velocities generally increase downward, but the trend is irregular. Local velocity inversions do exist, but no correlation with the top of geopressure is evident. Local zones of high velocities are noted in one velocity survey, but these may be artifacts, as at the Pleasant Bayou well.

\section{Time-Depth Conversion}

The wide scatter of interval velocities mentioned above is, however, not reflected in the time-to-depth curves (fig. 42), which show a relatively narrow range of variation for the velocity surveys and excellent agreement with velocity analyses. This narrow range of variation indicates that computer conversion of time sections to depth sections would be fairly accurate in this area and could be used for further structural analysis. 


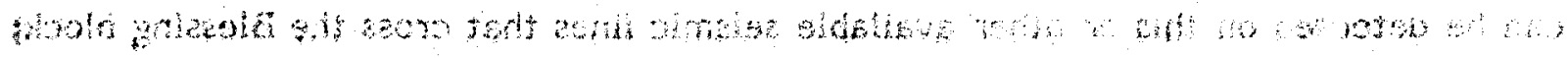

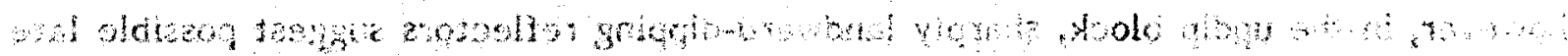

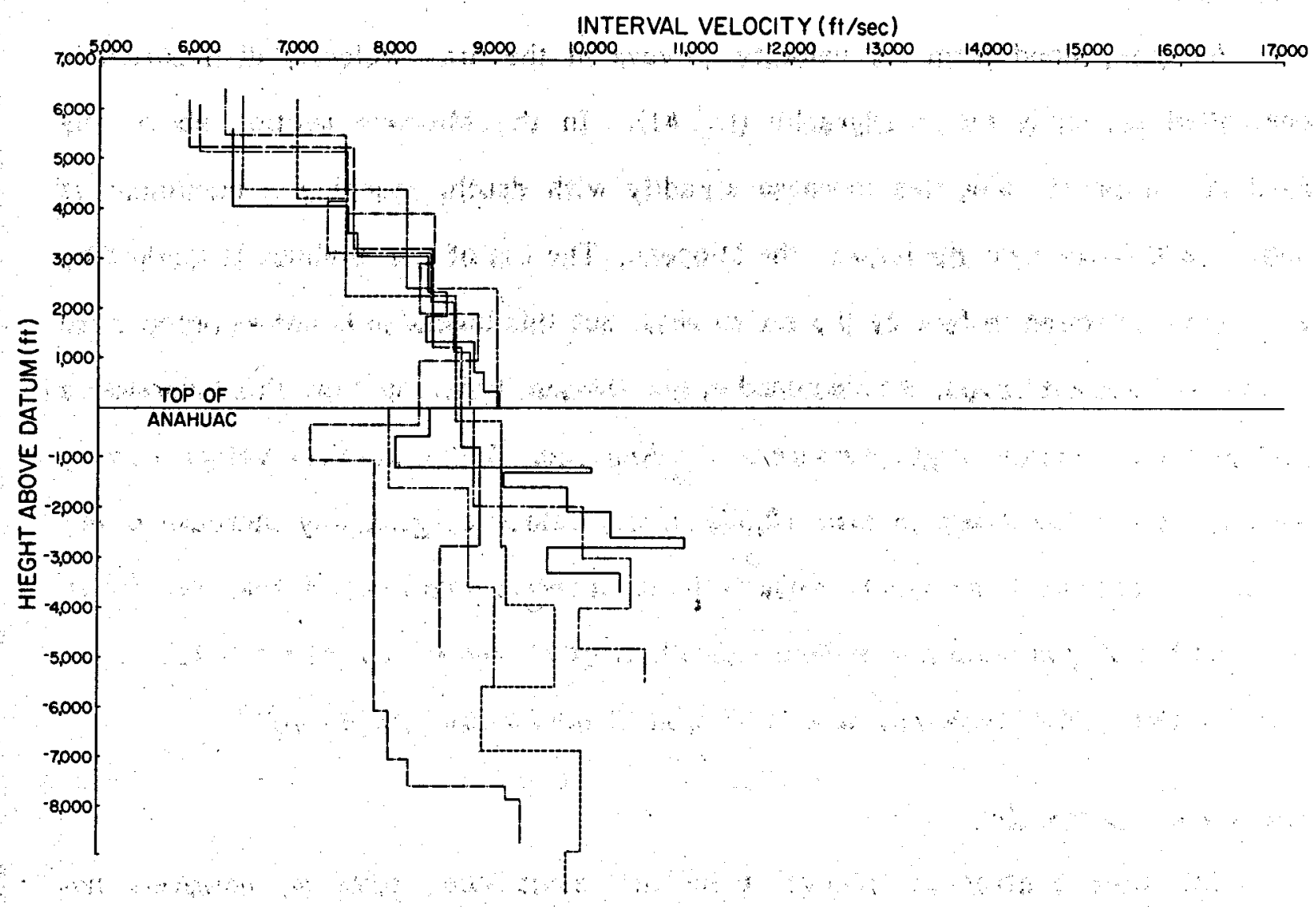

Figure 41. Interval velocities as determined from velocity surveys from six wells in the Blessing area. Datum is the top of the Anahuac, which in some wells marks a velocity inversion. 


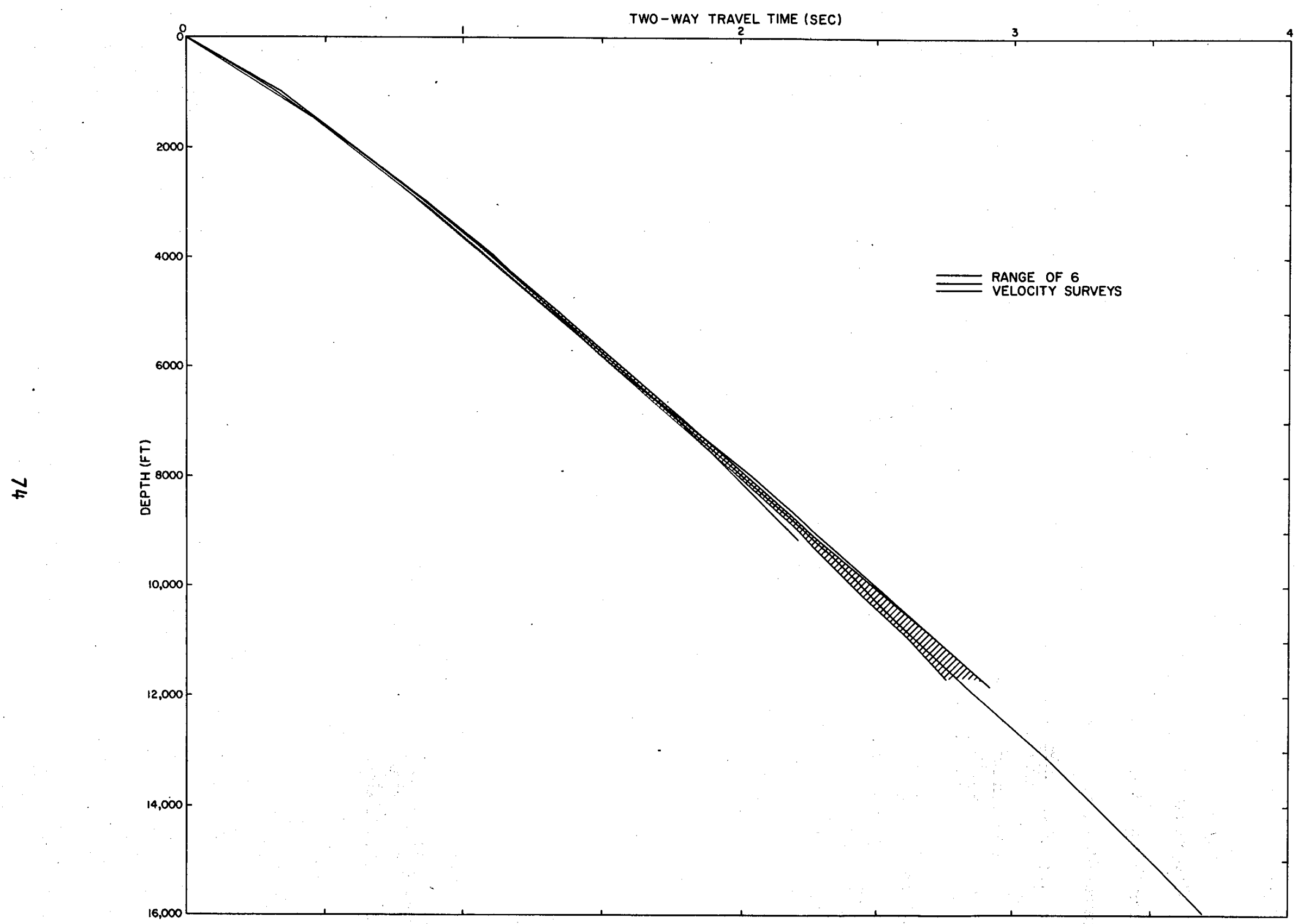

Figure 42. Range of time-depth curves obtained from six velocity surveys in the Blessing area. 


\section{CUERO AREA}

\section{Stratigraphic and Paleogeographic Setting}

Geopressured sandstones in the Cuero study area (fig. 1) occur in the lower Wilcox Group of late Paleocene to early Eocene age. Their absolute age is uncertain because of a lack of datable material in the sequence. The lower Wilcox is the first major influx of sand into the northwestern Gulf Basin during Tertiary time (table 9).

As a stratigraphic unit, the lower Wilcox is informally defined and subdivided. Its lower boundary with the Midway Group is gradational from sandstone above to shale below and is probably time-transgressive throughout the region. In this report, the top of the lower Wilcox is defined as the beginning of the middle Wilcox transgression, marked by a decrease in sandstone percentage (table 9). As with the lower boundary, the upper boundary is probably time-transgressive along strike and dip on a regional scale and does not correspond with the top of lower Wilcox used in earlier regional studies (Fisher and McGowen, 1967; Bebout and others, in press). Updip of the study area, the entire Wilcox section takes on a uniform character, and subdivision into upper, middle, and lower units becomes difficult.

The Cuero study area is situated on the southwestern fringe of the Rockdale delta system (Fisher and McGowen, 1967) in the area of transition from fluvial-deltaic facies to barrier-strandplain facies (fig. 43). This transition is marked by a decrease in net-sandstone thickness from northeast to southwest and from a lobate pattern to the northeast to a more linear, strike-oriented pattern to the southwest (fig. 44).

The Cuero study area is located along a trend of syndepositional down-to-thesouth faults that were most active during Wilcox time (fig. 45). This trend also marks a rapid downdip change in lithofacies, both in sandstone percentage and in log character. 
Table 9. Characteristics of operational stratigraphic units in the Cuero area.

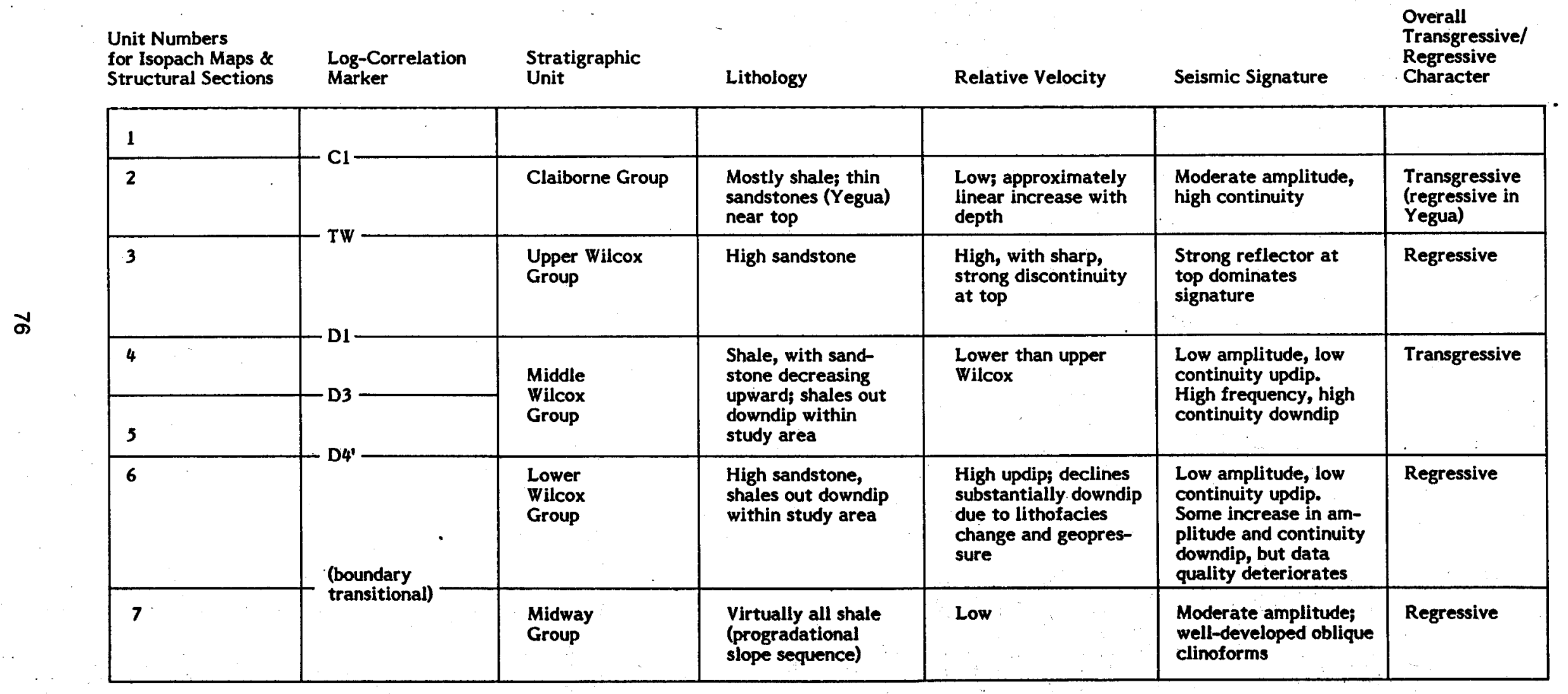




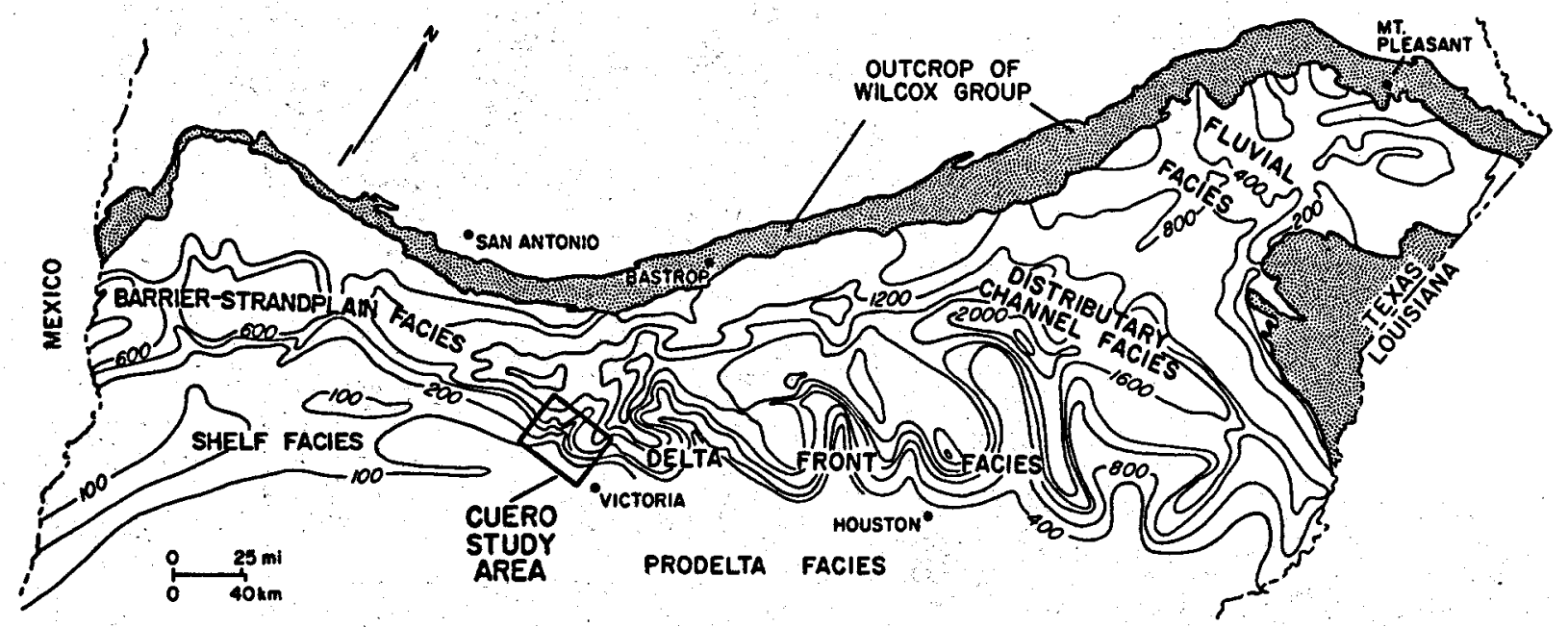

Figure 43. Location of Cuero study area in relation to Rockdale Delta system and barrier/strandplain facies. After Fisher and McGowen (1967). 


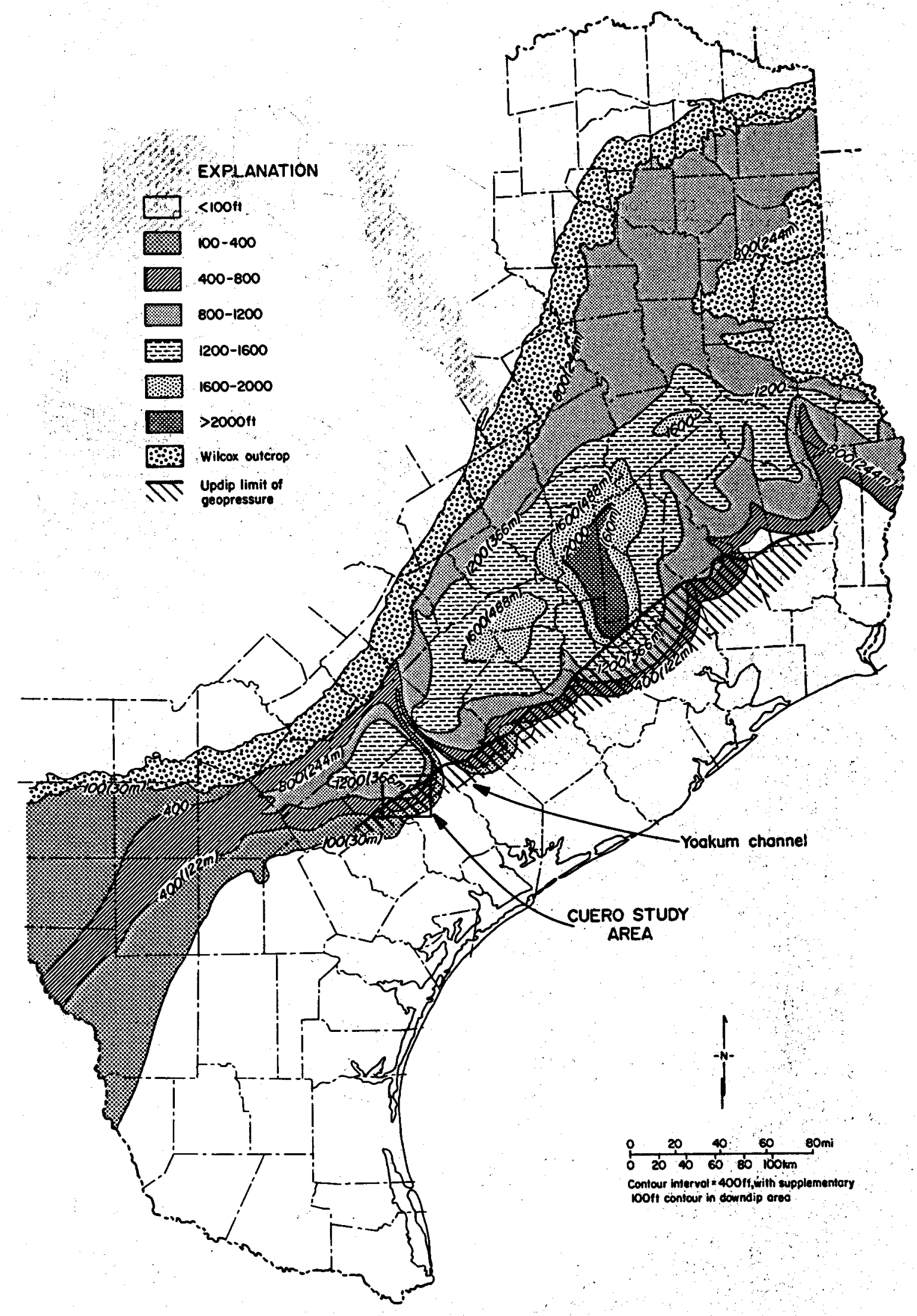

Figure 44. Location of Cuero study area in relation to net-sandstone distribution and upper limit of geopressure (based on mud weights) in the lower Wilcox. After Bebout and others (in press). 


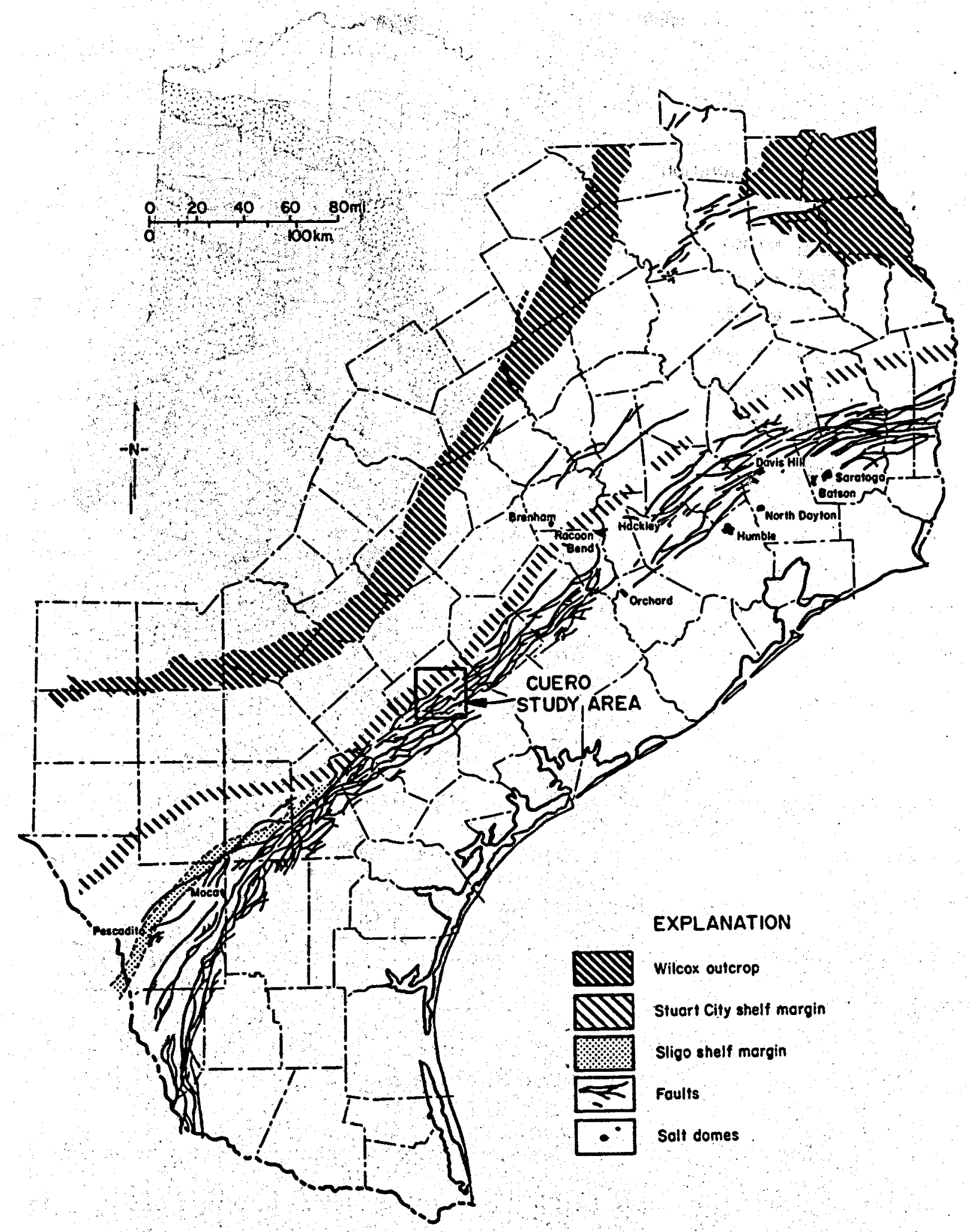

Figure 45. Location of Cuero study area in relation to regional Wilcox growth faults in Texas. After Bebout and others (in press). Fault map courtesy of Geomap, Inc. 
As a delta system comparable in scale to the Quaternary Mississippi delta, the Rockdale delta was probably fed by a large river system having a drainage basin of continental scale feeding into southeastern Texas. Petrographic study of subsurface Wilcox sandstones (Loucks and others, 1979) indicates a predominantly plutonic, metamorphic, and siliciclastic source area for the Wilcox in southeast Texas and only minor volcanic and carbonate contributions. The volcanic contribution increases toward the south; the Cuero study area is located between these two areas.

On the basis of high-grade metamorphic minerals in outcropping Wilcox sandstones, Todd and Folk (1957) proposed that the southern Appalachians provided the major source for Eocene sandstones in Texas, as opposed to the more conventional idea of the southern Rockies (Storm, 1945; Murray, 1955). We consider the southern Rockies as the more plausible source area because (1) they are much closer; (2) highgrade metamorphites crop out extensively in the southern Rockies, as well as in the Appalachians; (3) Eocene rocks in southern Georgia and Florida are predominantly clean carbonates (Toulmin, 1955), indicating that the southern Appalachians were not shedding much clastic detritus at the time; and (4) intermontane basins in New Mexico show a major increase in grain size about 55 m.y. (S. M. Cather, personal communication, 1981), indicating renewed activity of the southern Rockies about the same time as the lower Wilcox clastic influx. Low-grade metamorphic rock fragments are probably derived primarily from the Ouachitas, as Todd and Folk (1957) suggested:

\section{Operational Stratigraphy}

Site-specific description of the Cuero area (fig. 46) began with the correlation of distinctive electric-log markers (fig. 47). Where possible, these were chosen to correspond to boundaries of named stratigraphic units or major lithologic breaks (tables 2 and 9); markers TW, D1, and D3 were used in an earlier report on the Cuero area (Bebout and others, in press). Stratigraphic units bounded by these markers were 


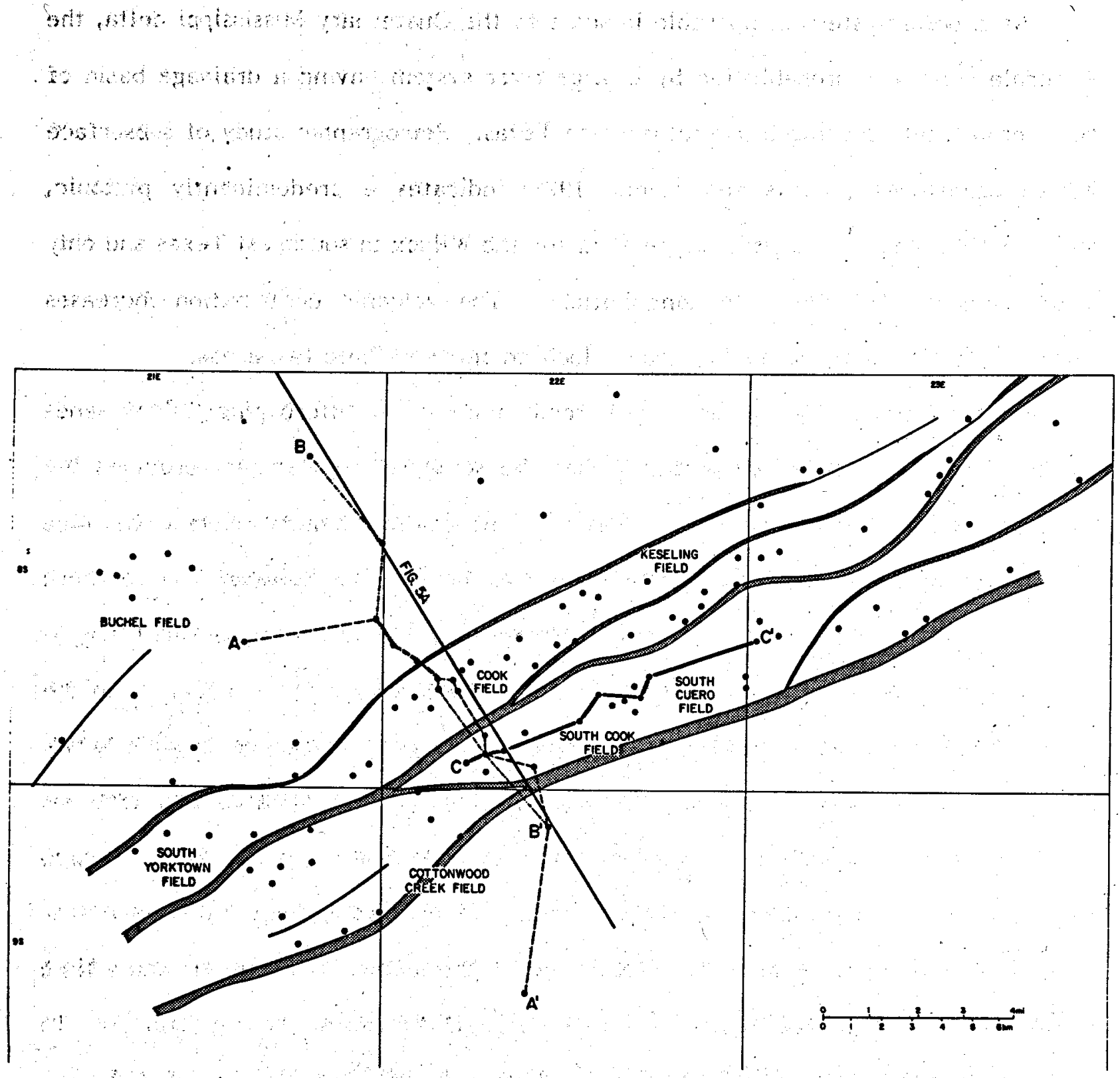

Figure 46. Data base and locations of well-log sections, Cuero study area. 


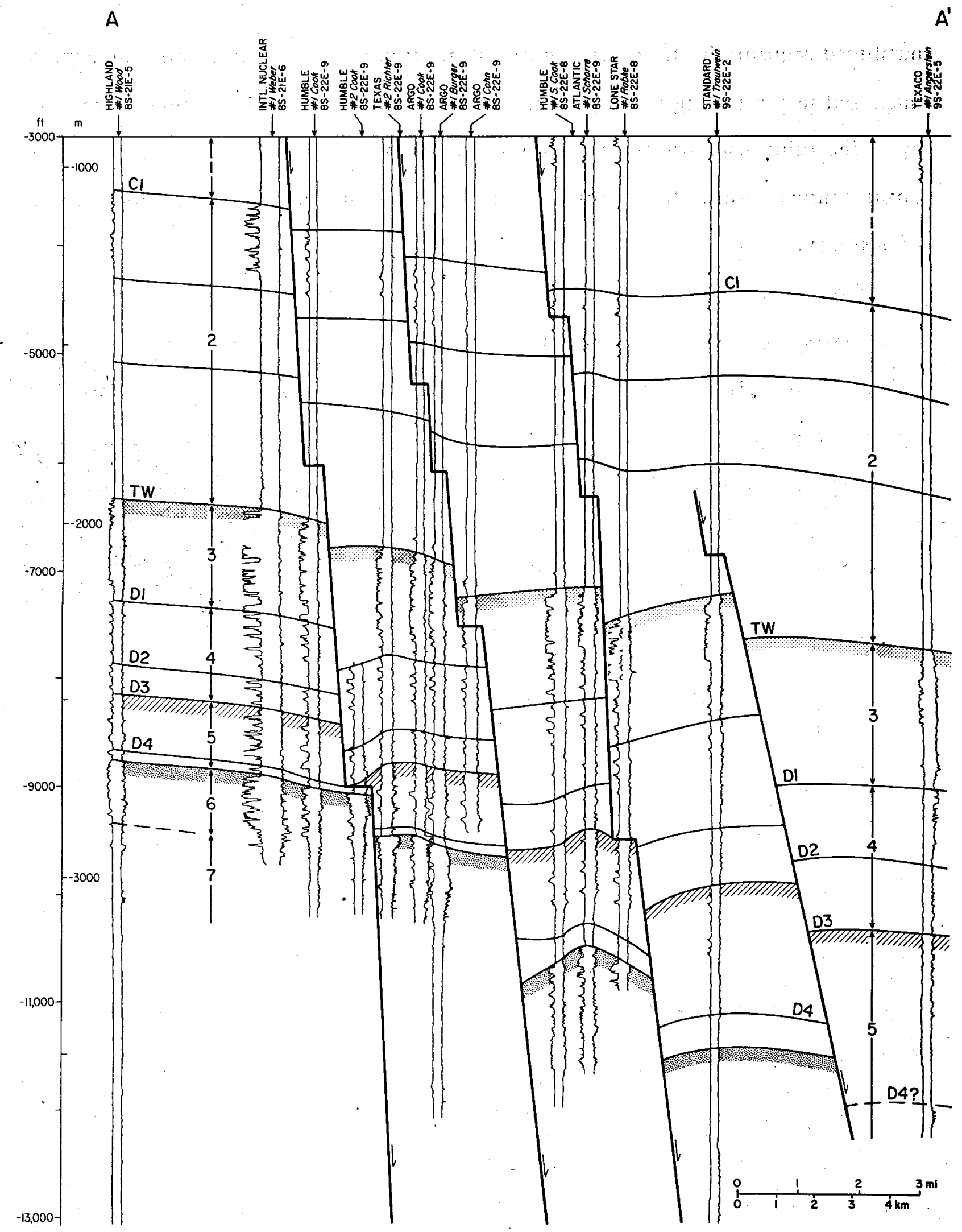

Figure 47. Structural dip section of Cuero study area, illustrating log character of stratigraphic units (table 9). 
numbered sequentially from youngest to oldest (tables 2 and 9) to simplify labeling of maps and sections. Log markers were also transferred to seismic sections where tied by wells, using appropriate velocity surveys for the conversion from depth to time. These markers were then traced through the seismic grid to check for internal consistency.

Correlation was mostly straightforward; the only serious difficulties were encountered with D3 and D4' downdip of the fault block of interest. The base of the Wilcox is difficult to correlate in that it is transitional and time-transgressive and probably represents a change from topset to foreset stratification. Therefore, no correlatable log marker could be found to clearly mark an operational base of Wilcox.

\section{Structural Setting}

The location of the Cuero study area along the Wilcox growth-fault trend limits the potential size of Wilcox geothermal reservoirs. These growth faults resulted from large-scale basinward sliding of the continental slope, which created an extensional regime along the shelf margin. Wilcox growth faults tend to be subparallel as well as closely.and evenly spaced, particularly when compared with Vicksburg and Frio growth faults. Shale diapirism has apparently not been a major factor in the Wilcox structural style, also unlike the Vicksburg and Frio. The relatively simple structural style of the

Wilcox appears to be typical of the initial style of growth faulting that forms as a shelf margin progrades into a basin and becomes increasingly unstable (Winker and Edwards, in press).

\section{Local Structure}

Structure and interval isopach maps were constructed on all five correlation markers using well logs (fig. 46) and seismic data. Because of the density of well control, final mapping was based primarily on log correlation. Seismic lines were used 
primarily to verify the structural style, to check the direction and angle of fault dip, and to extend the structural interpretation below and downdip of the area of dense well control. The resulting structure map on the zone of interest (D4') is a moderate departure from that obtained in the initial study of this area (Bebout and others, in press).

\section{Structural Style}

The structural style in the Cuero area (figs. 5, 45, 48, 49, and 50) is typical of the lower Wilcox trend. Growth faults are virtually all down-to-the-south, with relatively small throw and minor rollover, which is nonetheless sufficient to create anticlinal closures within fault blocks. Fault traces are subparallel and fairly evenly and closely spaced, and faults dip at an average of approximately $45^{\circ}$ (fig. 5). The overall result is long, narrow fault blocks with very low structural relief; this style changes little from one mapping horizon to the next (figs. 48, 49, and 50). The small amount of rollover indicates that the faults flatten at considerable depth into a décollement surface or zone. This décollement is probably below the Lower Cretaceous Edwards Limestone and may be in thin, non-diapiric Jurassic salt.

The beginning of growth-faulting corresponds to the Midway-Wilcox.stratigraphic boundary. A number of possible explanations for this timing include the following: (1) Growth faulting began once the shelf margin prograded beyond the buried Lower Cretaceous shelf edge; this may have allowed the shale section to attain the critical thickness (Crans and others, 1980) for gravity sliding. (2) Growth faulting began with a major influx of sand; therefore, growth faulting could have been caused by loading of sand on shale (Bruce, 1973). (3) If décollement took place in non-diapiric salt, growth faulting may have begun once the shelf margin reached the updip limit of salt, which permitted large-scale gravity sliding. It should be noted that the presence of salt has not been documented in this part of the Gulf Basin; its presence is nearly impossible to detect with present technology. 


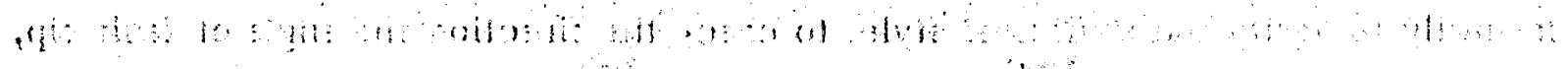

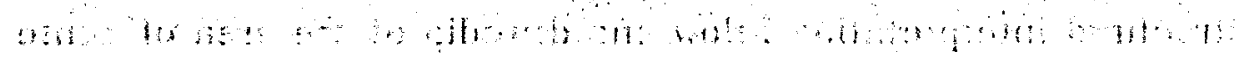

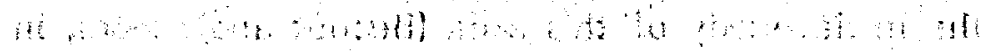

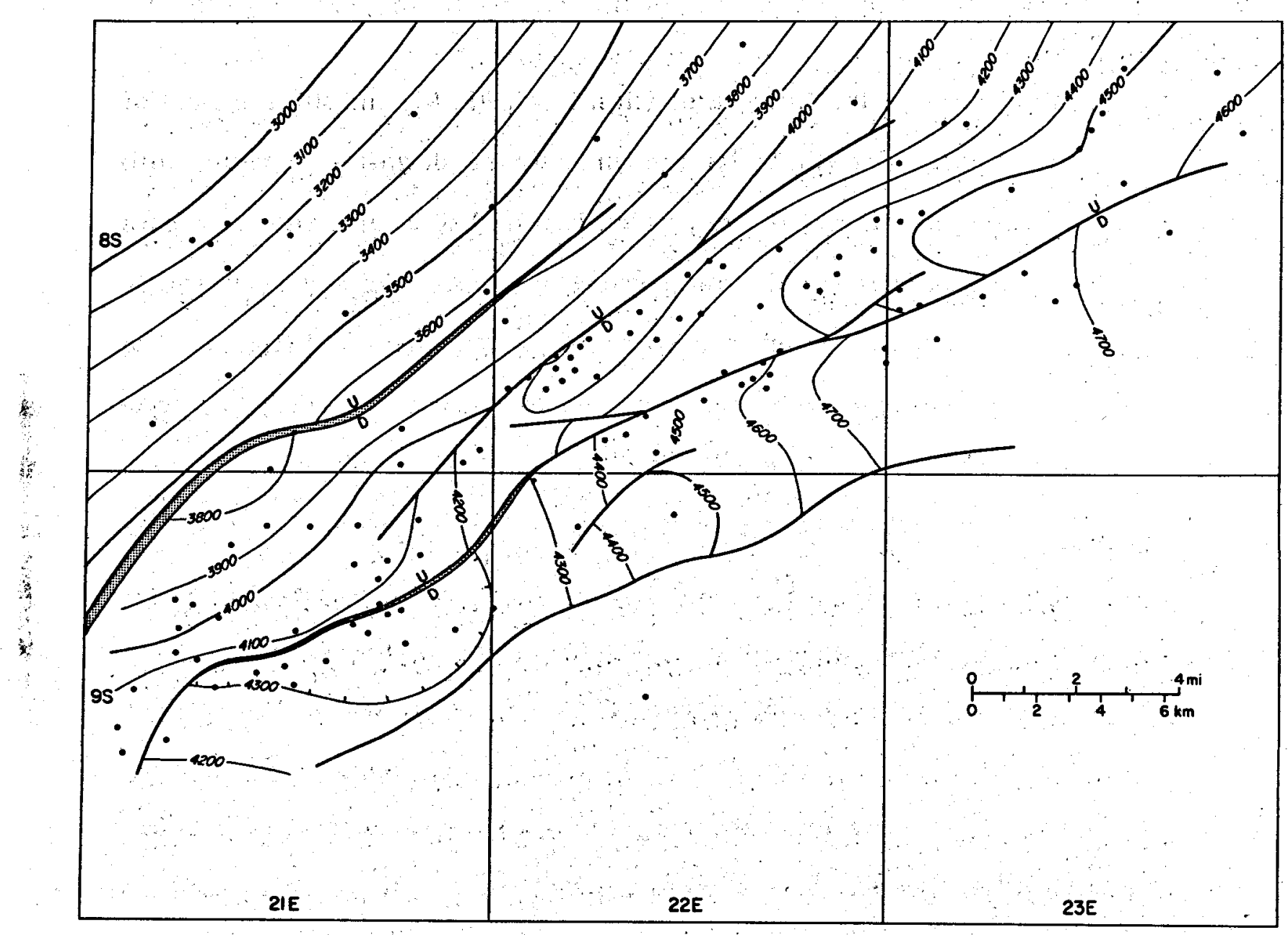

Figure 48. Structure contour map of $\mathrm{Cl}$ correlation marker (top of Yegua). 


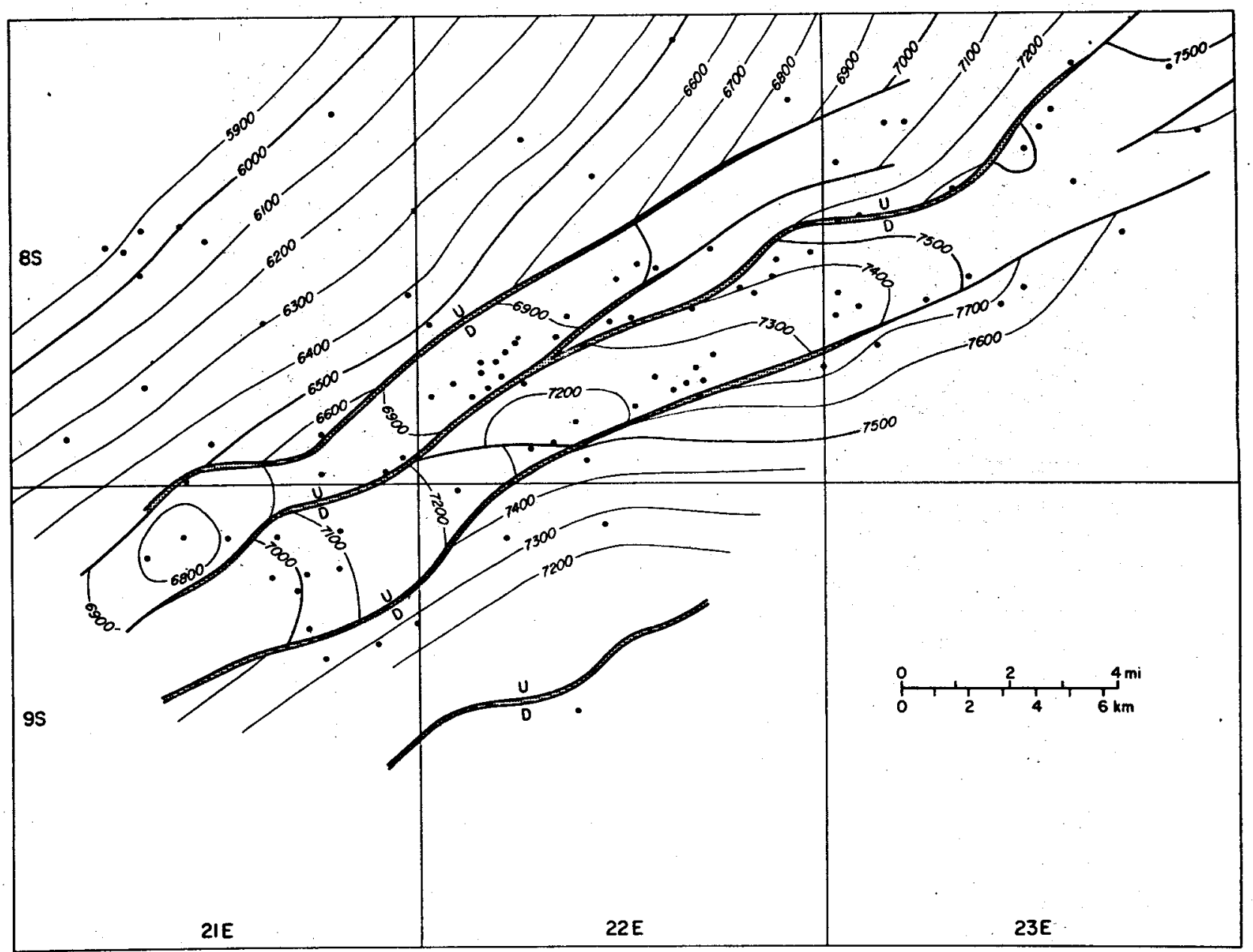

Figure 49. Structure contour map of T.W correlation marker (top of Wilcox). 


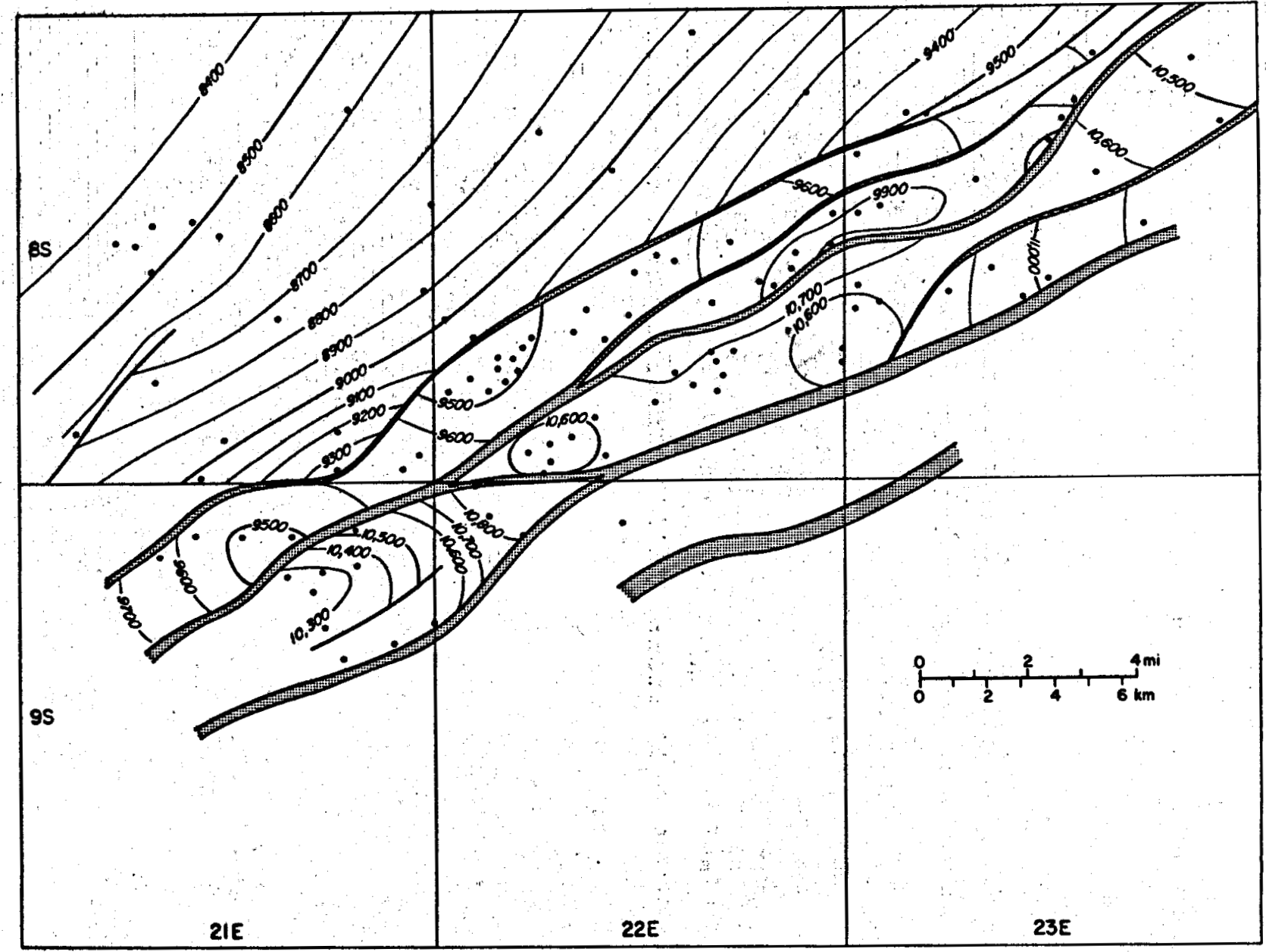

Figure 50. Structure contour map of D4' correlation marker (local top of lower Wilcox). First fault is post-depositional; second fault marks the updip limit of geopressure. Gas is produced from gentle rollover anticlines. 
Structural Evolution

Structural evolution of the Cuero area was studied by means of sequential isopach maps (fig. 51) in the same manner as was the Pleasant Bayou and Blessing areas. Reconstruction of the earliest structural growth is hampered by the difficulty in correlating any marker below D4'; the Wilcox-Midway boundary is transitional and probably time transgressive. From stratigraphic dip sections hung on D4', it appears that faults bounding the South Cook field were active during early Wilcox time and had growth ratios of about 2. In interval 5 (middle Wilcox), these same faults continued to move, but growth ratios decreased below 2. This early, relatively rapid growth isolated lower Wilcox sandstones and permitted geopressure to build up. The fault farthest updip did not begin to move until the time of deposition of interval 4 (uppermiddle Wilcox); this fault did not create a geopressure trap. The growth ratios of other faults declined with time; by the time of deposition of interval 2 (Claiborne), growth ratios had dropped below 1.1. By this time, the shelf margin had prograded approximately 20 to $30 \mathrm{mi}$ basinward of its position in early Wilcox time. In postClaiborne time (representing approximately $40 \mathrm{m.y.}$ ), the main structural activity was regional southeastward tilting. In spite of the tilting, closure of rollover anticlines was maintained.

\section{Sandstone Facies}

Sandstone facies in the lower Wilcox were classified on the basis of SP pattern and on continuity of individual sandstones; five environments were inferred from these log facies (table 10). Spatial relationships among these facies are summarized by two stratigraphic sections (figs. 52 and 53) and a paleogeographic map (fig. 54). The stratigraphic dip section (fig. 52) shows the basic progression of facies associated with progradation: slope shales (characterized by clinoform reflectors on seismic sections) 


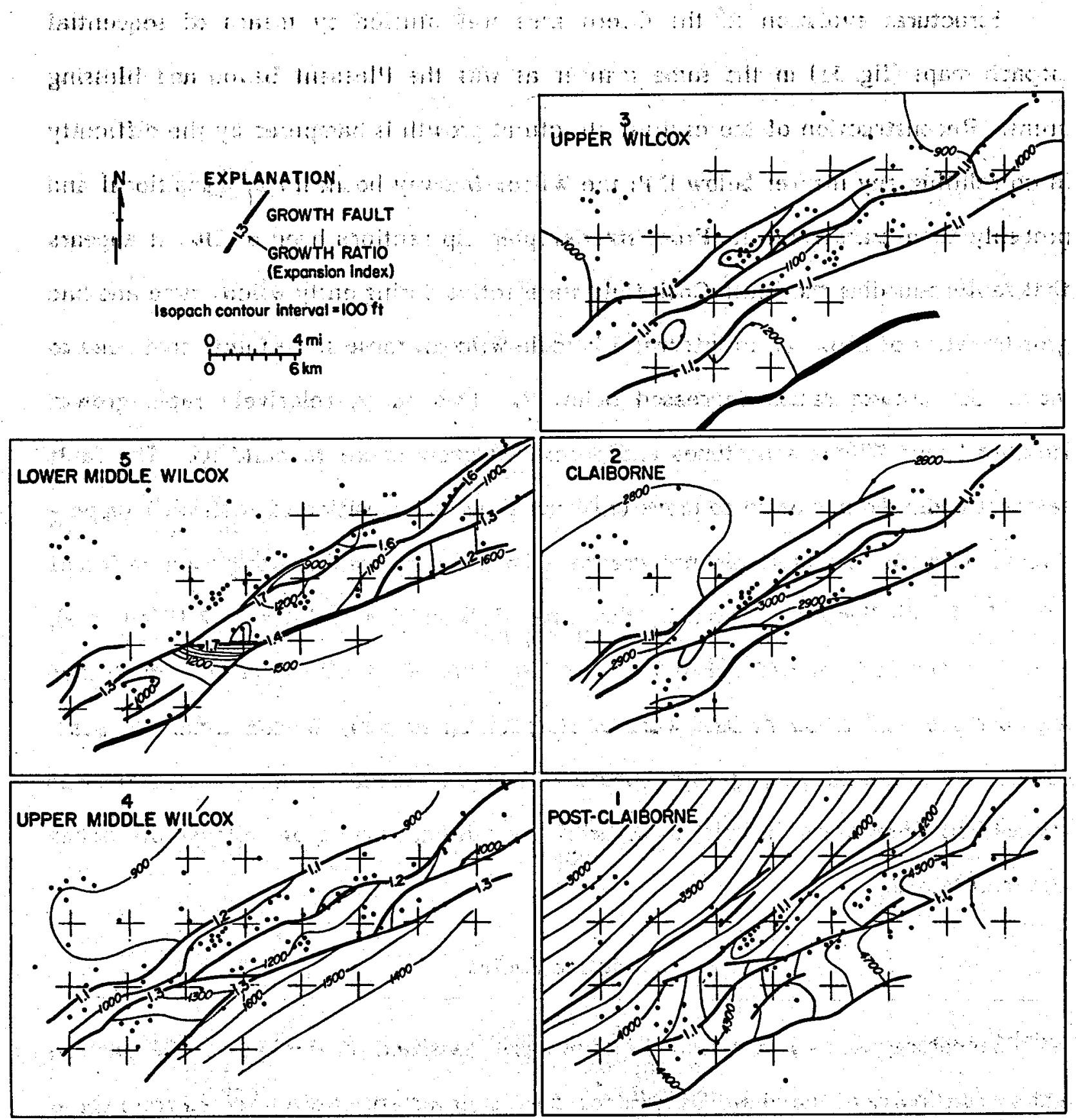

Figure 51. Sequential isopach maps illustrating structural evolution of Cuero study area. Distortion of grid is caused by removal of horizontal component of postdepositional faulting. 
Table 10. Electric-log facies in the lower Wilcox (unit 6), used for paleogeographic mapping in the Cuero area.

$\begin{array}{lll}\text { Environmental } & \text { Log } & \begin{array}{l}\text { Geographic } \\ \text { Distribution }\end{array} \\ \text { Chterpretation } & \text { Chacteristics } & \text { Distion }\end{array}$

Fluvial/deltaic plain
High sandstone, blocky patterns; laterally discontinuous (individual sands cannot be correlated)

Thin sandstones, mostly upward-coarsening, high lateral continuity
Updip of growth faults; to northeast; toward Rockdale Delta

Mostly updip of growth faults; to southwest of fluvial/deltaic-plain facies

Delta front

Similar to strandplain facies*

Along growthfault trend, basinward of fluvial/ deltaic-plain facies

Distributary channel

Thick sandstones, blocky to upward-fining, few shale breaks
Within growthfault trend, laterally continuous with delta-front sandstones

Prodelta/slope

Low sandstone; greatly expanded section; correlation virtually impossible"
Downdip of main fault block

* Similar pattern also observed below fluvial/deltaic-plain facies in Midway-Wilcox transition. 


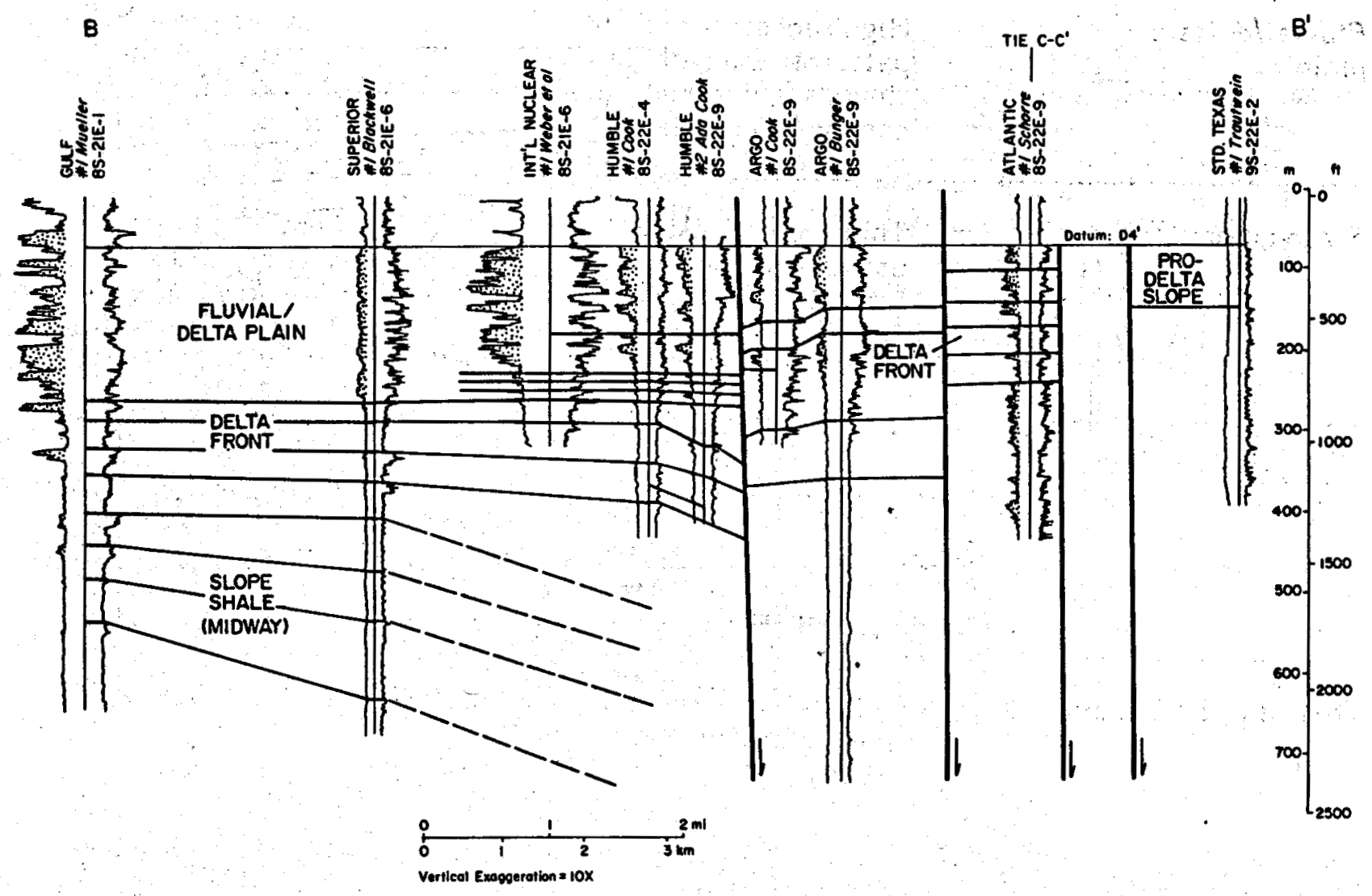

Figure 52. Stratigraphic dip section of lower Wilcox, illustrating changes in log character and expansion of section across second and third growth faults. 
C
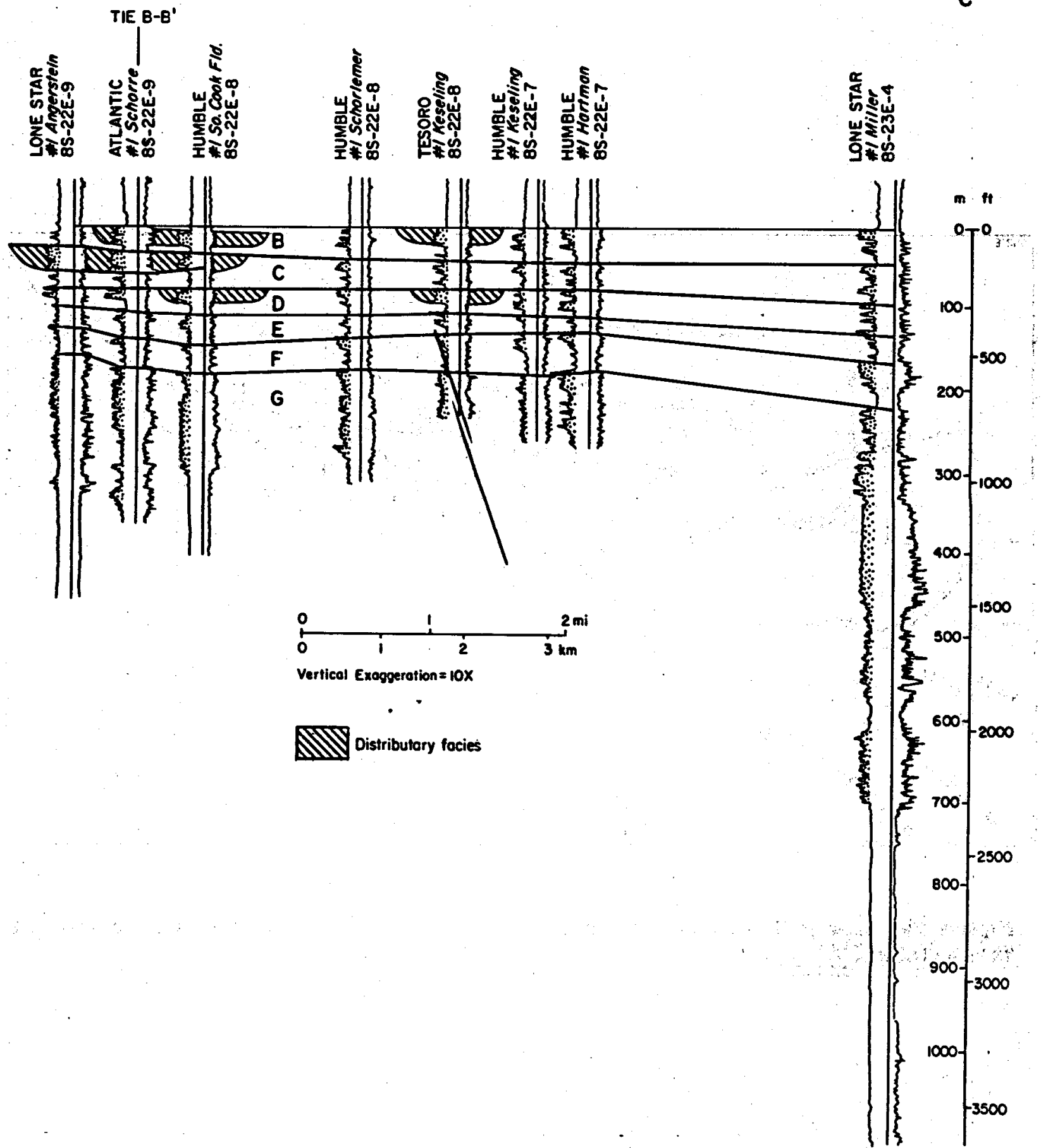

Figure 53. Stratigraphic strike section of lower Wilcox in South Cook fault block, illustrating distributary sandstone facies laterally continuous with delta-front facies. 


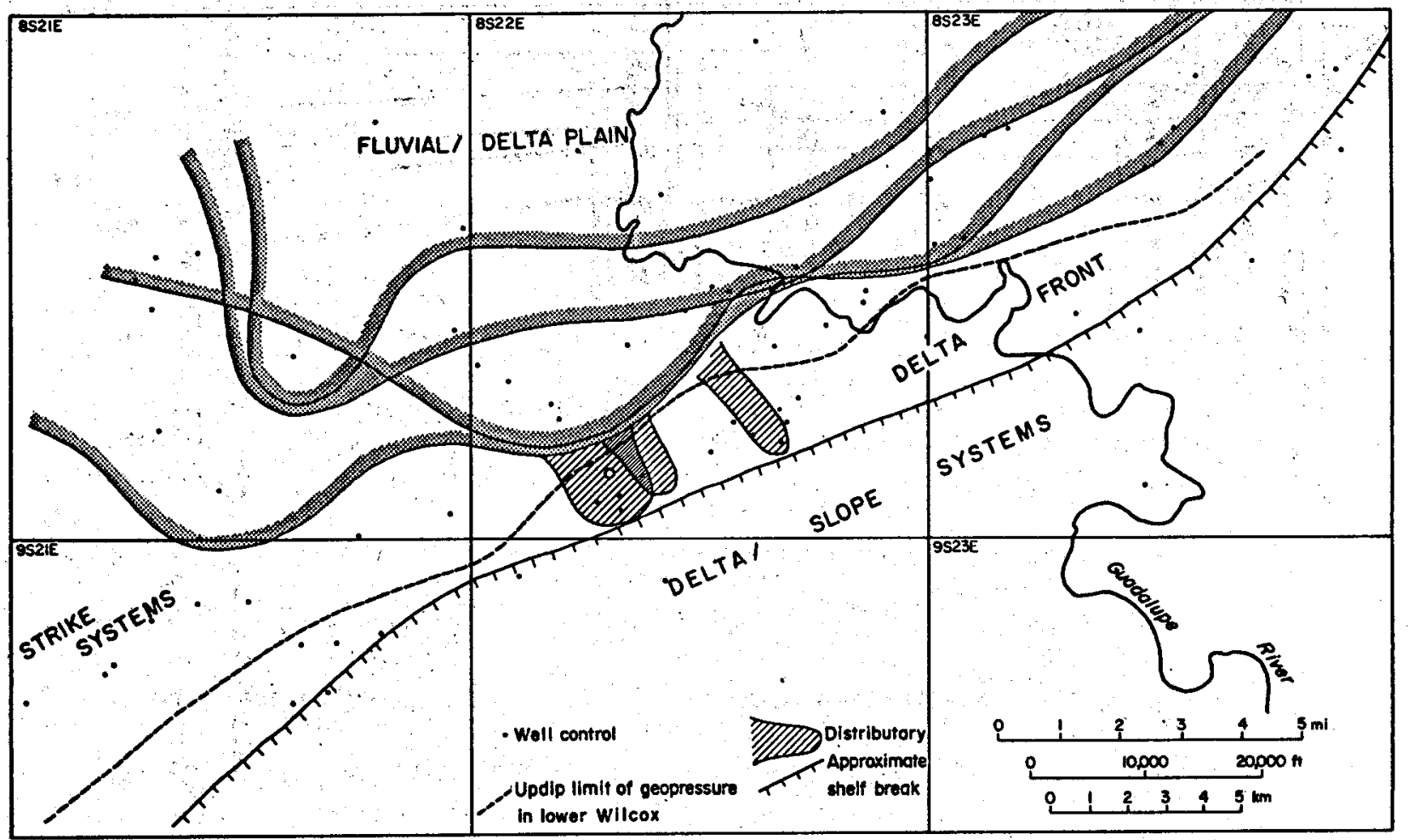

Figure 54. Lower Wilcox paleogeography of Cuero study area, based on electric-log facies (table 10). 
overlain by delta-front sandstones, in turn, overlain by the fluvial/deltaic-plain facies of sandstones and shales. A similar progression can be seen in a basinward direction on the same section, although the pattern is complicated somewhat by expansion of the section across growth faults. On a strike section within the main fault block (fig. 53), delta-front sandstones are seen to grade laterally into thick, blocky or upward-fining sandstones, interpreted as distributary channel-fill or channel-mouth bars (fig. 55). These distributary sandstones exhibit high permeabilities $(>100 \mathrm{md})$ in the Atlantic Schorre \#1 well (fig. 56).

In plan view (fig. 54), the distribution of sandstone facies reflects the paleogeographic relationships of the Rockdale delta system as a whole (fig. 43). The Cuero area lies in a transition from predominantly deltaic systems, with fluvial/deltaic-plain facies grading downdip into delta-front and distributary facies, to predominantly strike-fed barrier/strandplain facies characterized by high continuity along strike and dip.

Within the geopressured part of the lower Wilcox, distributary sandstones exhibit the best potential as geothermal reservoirs. However, the small areal extent of these sandstones (figs. 16, 54, and 55) places severe restrictions on the possible location and producing volume of a geothermal well. Ideally, a well site should be chosen to intersect two or more overlapping sandstones of high potential. In the case of the Cuero area, there is insufficient latitude in well-site location to avoid interference with existing conventional gas production from the South Cook field (fig. 55).

\section{Pressure Distribution}

Pressure distribution in the Cuero area is easily delineated by a combination of drill-stem test, mud weight, and shale resistivity data (fig. 57). As a general rule, drill-stem tests (BHSIP) tend to underestimate true formation pressures because time 


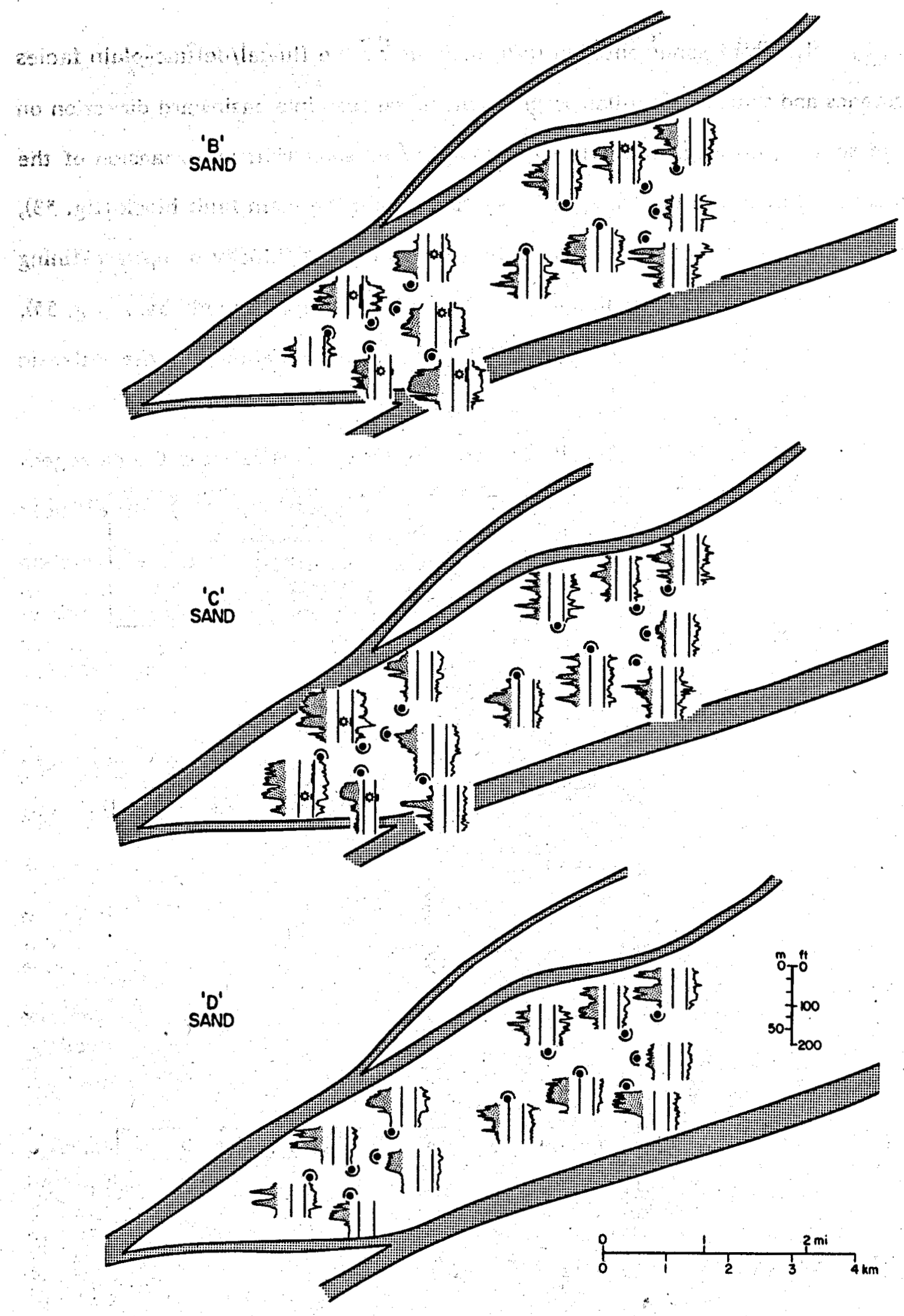

Figure 55. Log patterns of three lower Wilcox sandstones in the South Cook fault block, illustrating facies changes from distributary to delta front, and gas-well completions. 


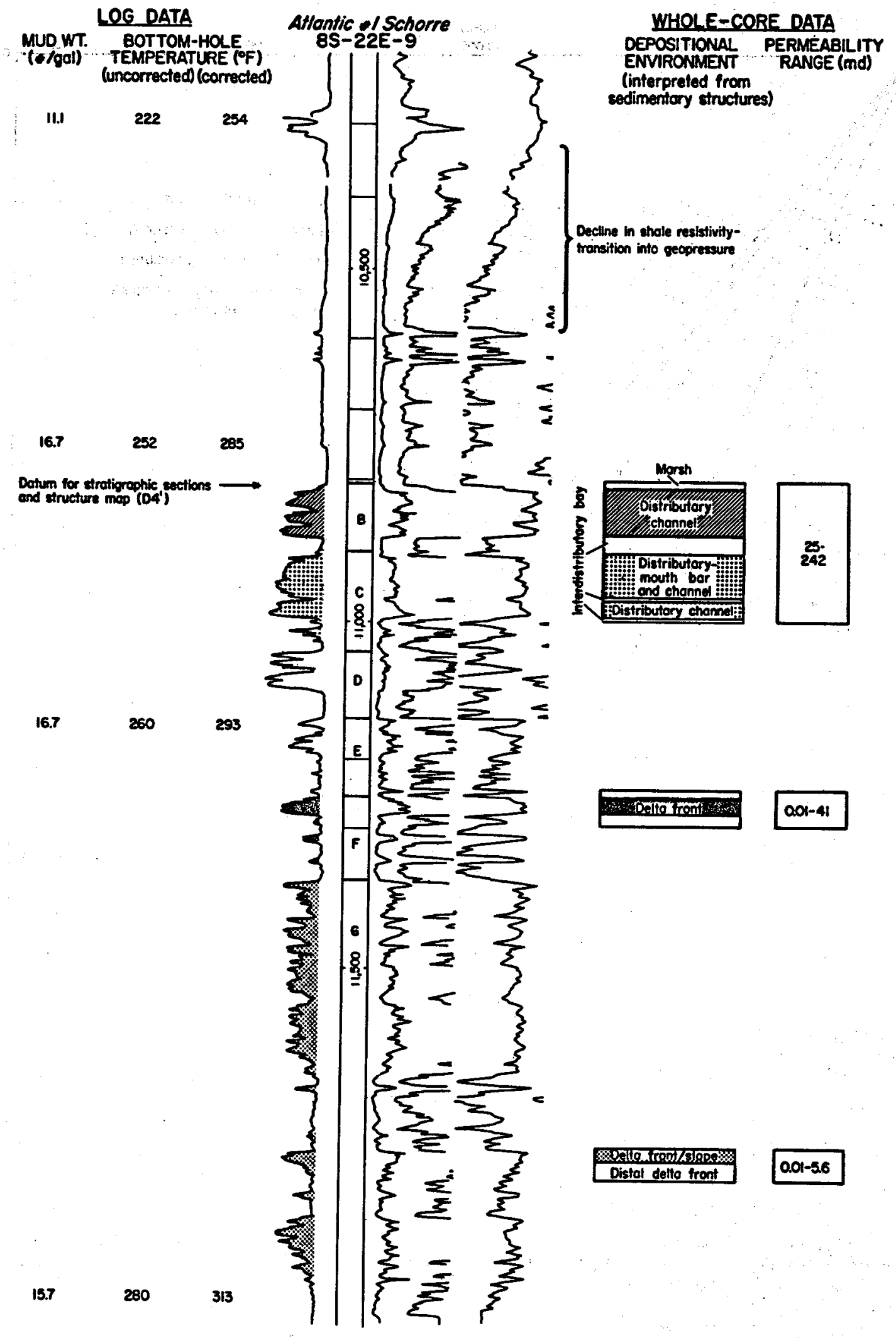

Figure 56. Electric log with permeability data and environmental interpretations (based on whole core) for lower Wilcox section, Atlantic \#1 Schorre (type well). 


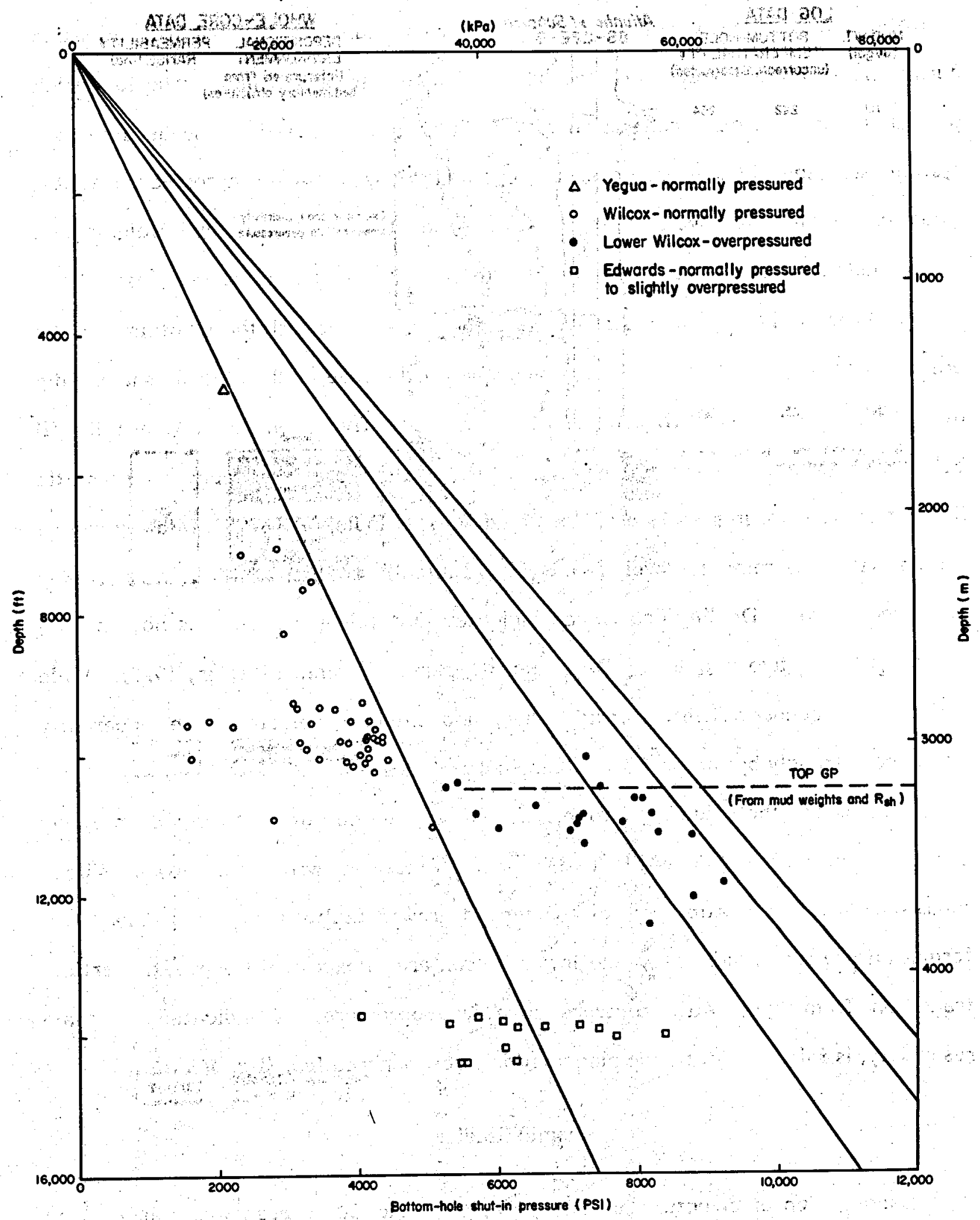

Figure 57. Plot of bottom-hole shut-in pressures (BHSIP) versus depth from gas wells in DeWitt County. Note well-defined top of geopressure. 
limitations may prevent well bore-pressures from equilibrating with the formation during the test. Mud weights, on the other hand, tend to overestimate true formation pressures when a simple conversion of units ( $\mathrm{lb} / \mathrm{gal}$ to $\mathrm{psi} / \mathrm{ft}$ ) is made because mud systems are generally overbalanced. Dickinson (1953) recommends a correction factor when converting mud weights to pressure gradients. Between mud weights and bottom-hole shut-in pressures, it is possible to bracket the true formation pressure.

Shale-resistivity plots generally give results consistent with those obtained in the preceding fashion (fig. 58). An exception occurs in the case of the Midway shale updip of the growth-fault trend (figs. 59 and 60). Shale resistivities in the Midway fall well below the normal compaction curve, suggesting fluid pressures above hydrostatic (Bebout and others, in press). However, mud weights indicate that the Midway can be drilled with the same low-weight muds $(<13 \mathrm{lb} / \mathrm{gal})$ used for drilling the normally pressured Wilcox. Drilling experience indicates that full geopressure is not encountered until the Sligo is reached (D. G. Bebout, personal communication, 1979). Shale resistivities, conductivities, transit times, and interval velocities are apparently influenced strongly by factors other than fluid pressure.

Except for the Midway section, the various sources of data provide a fairly consistent picture of pressure distribution. Pressures within the lower Wilcox sandstones are hydrostatic updip of the second growth fault. Downdip of this fault, formation pressure gradients in the lower Wilcox are in excess of $0.7 \mathrm{psi} / \mathrm{ft}$. Vertical transition from hydrostatic pressure to full geopressure, as indicated by shale resistivity, is fairly rapid, taking place within a few hundred feet (fig. 56).

\section{Seismic Studies}

Examination of structure and stratigraphy in the Cuero area was enhanced by $35.9 \mathrm{mi}$ of proprietary seismic lines and 25.1 additional miles of seismic lines shot for this study (table 11, fig. 61). 


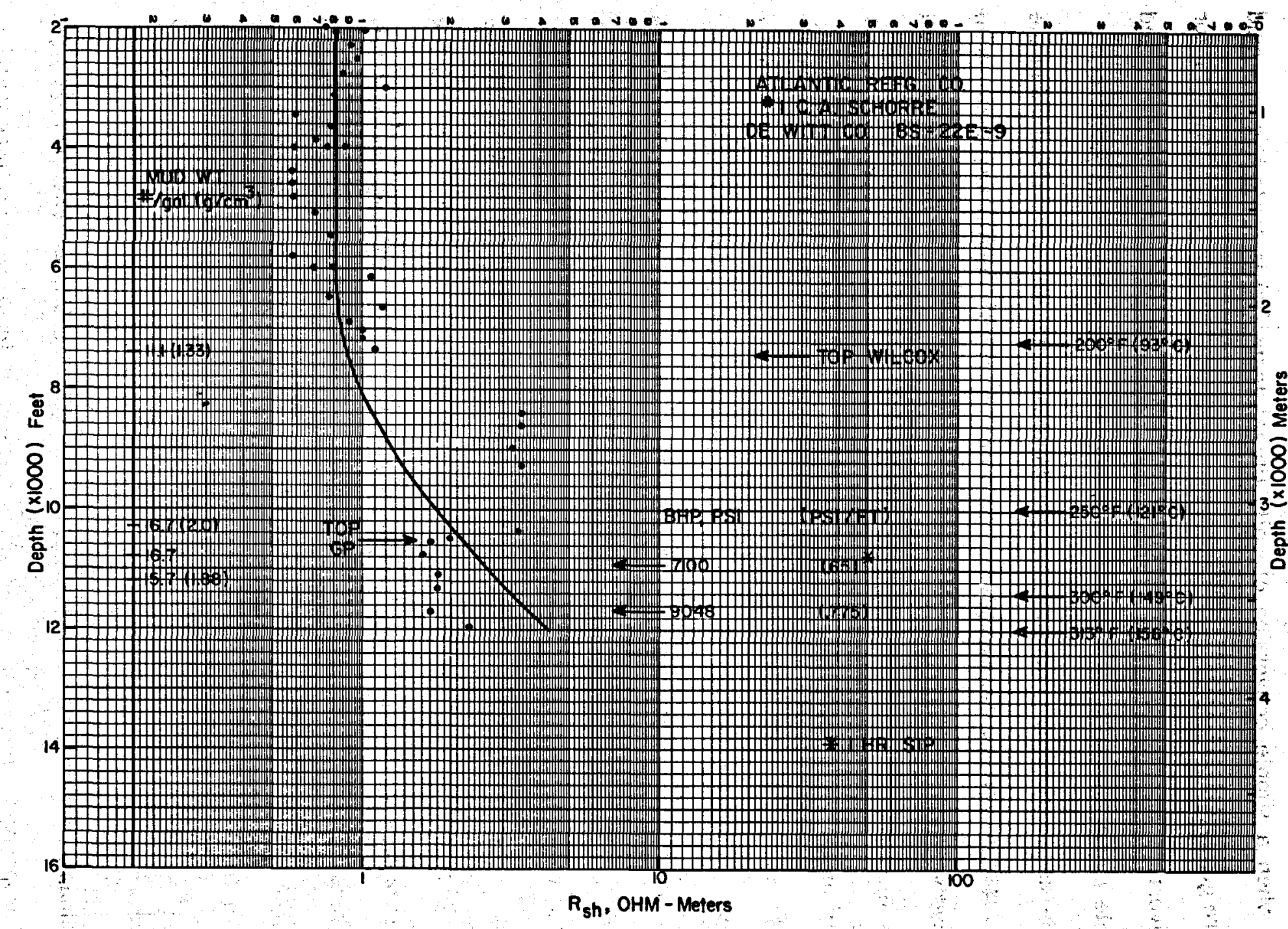

Figure 58. Shale-resistivity plot for Atlantic \#1 Schorre (type well) used to estimate pressure gradients. Shale resistivity and mud weights yield consistent estimates and place top of geopressure just above D 4' marker. After Bebout and others (in press). 


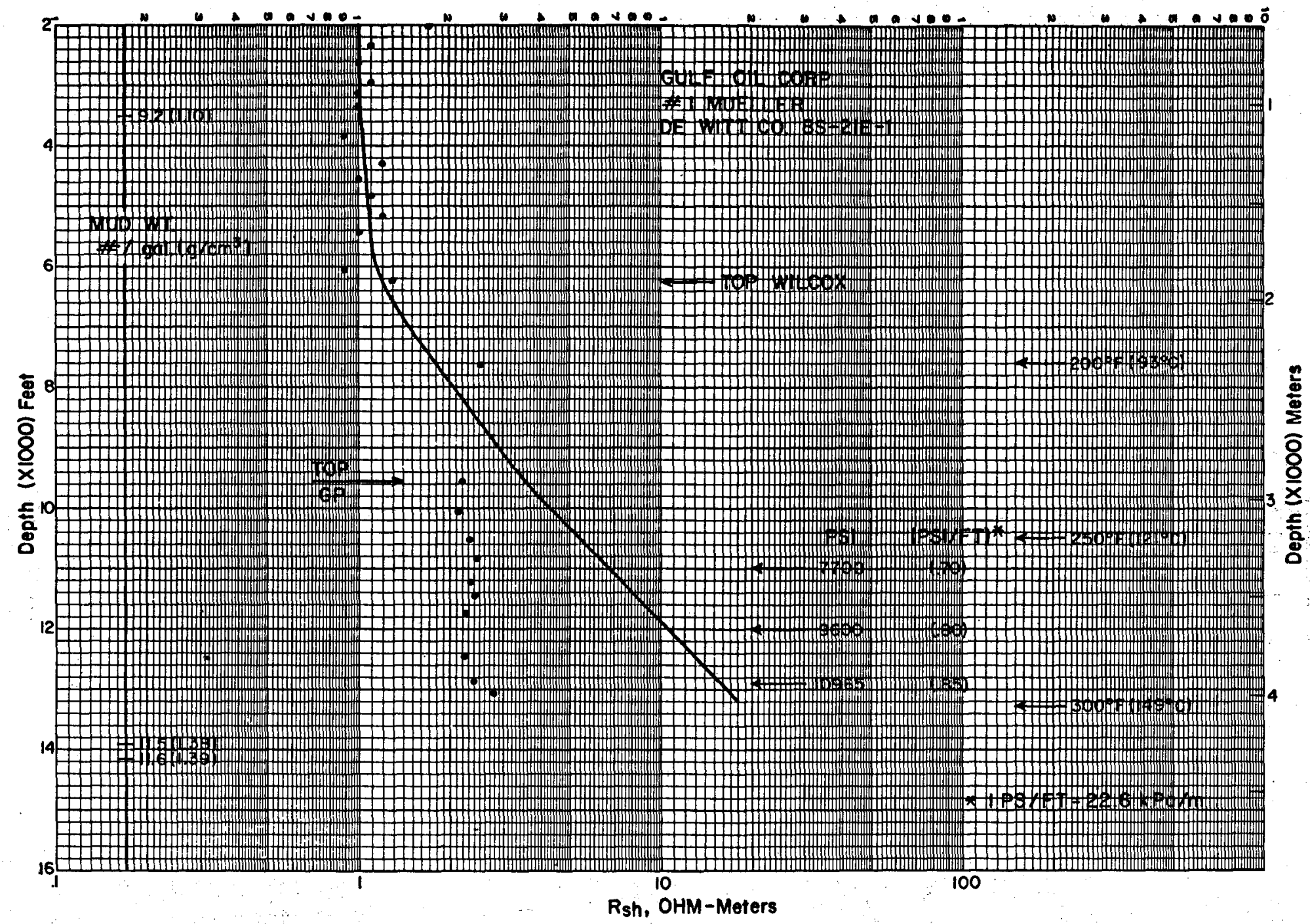

Figure 59. Shale-resistivity plot for Gulf 非 1 Mueller well, Stuart City trend, updip of Wilcox growth faults. Shale resistivities indicate top of geopressure in Midway shale, whereas mud weights indicate normal pressure above the Edwards carbonates. After Bebout and others (in press). 
D :

INTERNATIONAL

TANA.

ATLANTIC

HI TANA.

\#1 Schorre
8S-22E-9

KILROY

Al Muelter

9S-22E-3

8S-22E-9

Rsh, $\Omega-m$

8S-2IE-6

$R_{s h, \Omega-m}$ SHALE

$8 S-2 I E-1$
$R_{3 h, n-m}$

.123

IIT RESISTIVITY 5124 TOP WILCOX $\{$ GRADIENTS

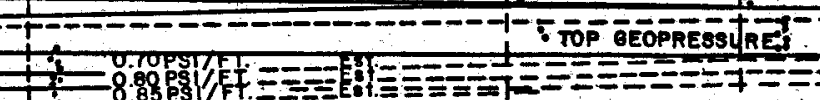

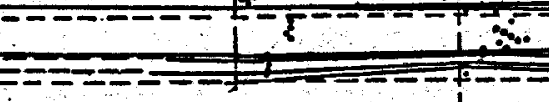

TEXACO

$D^{\prime}$

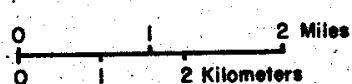

2 Milos

Figure 60. Parameter plots for wells in section in figure 47, illustrating top of geopressure as picked from shale resistivities. After Bebout and others (in press). 
Table 11. Seismic lines acquired for evaluation of the Cuero area.

\begin{tabular}{|c|c|c|c|c|c|c|c|c|c|}
\hline Line & Shot by & Date & $\begin{array}{c}\text { Fold } \\
\text { (Nominal) }\end{array}$ & $\begin{array}{c}\text { Maximum } \\
\text { Offset } \\
\text { (ft) }\end{array}$ & $\begin{array}{l}\text { Length } \\
\text { (mi) }\end{array}$ & $\begin{array}{c}\text { Pata } \\
\text { Quality at } \\
\text { Depth of } \\
\text { Interest }\end{array}$ & $\begin{array}{c}\text { Reprocessed } \\
\text { by H.P.I. }\end{array}$ & Migrated & Orientation \\
\hline $\begin{array}{l}7 F-2 \\
14 W-F \\
U T-1 \\
U T-1 A \\
\text { UT-2 } \\
\text { UT-3 } \\
\text { UT-4 }\end{array}$ & $\begin{array}{l}\text { Arco } \\
\text { Teledyne } \\
\text { Geosource (for UT) } \\
\text { " } \\
\text { " } \\
\text { " }\end{array}$ & $\begin{array}{r}7 / 68 \\
9 / 70 \\
5 / 80 \\
5 / 80 \\
11 / 79 \\
3 / 80 \\
4 / 80\end{array}$ & $\begin{array}{r}6 \\
6 \\
24 \\
24 \\
24 \\
24 \\
24\end{array}$ & $\begin{array}{r}5,500 \\
8,250 \\
10,800 \\
10,800 \\
10,800 \\
10,800 \\
10,800\end{array}$ & $\begin{array}{l}15.4 \\
20.5 \\
3.1 \\
2.3 \\
6.0 \\
7.4 \\
6.3\end{array}$ & $\begin{array}{l}\text { Fair } \\
\text { Fair } \\
\text { Poor } \\
\text { Poor } \\
\text { Good } \\
\text { Fair } \\
\text { Fair }\end{array}$ & $\begin{array}{l}\mathbf{x} \\
\mathbf{x}\end{array}$ & $\begin{array}{l}\mathbf{x} \\
\mathbf{x} \\
\mathbf{x} \\
\mathbf{x} \\
\mathbf{x}\end{array}$ & $\begin{array}{l}\text { Dip to oblique } \\
\text { Dip } \\
\text { Strike } \\
\text { Strike } \\
\text { Dip } \\
\text { Dip } \\
\text { Dip }\end{array}$ \\
\hline
\end{tabular}

'ำ. 


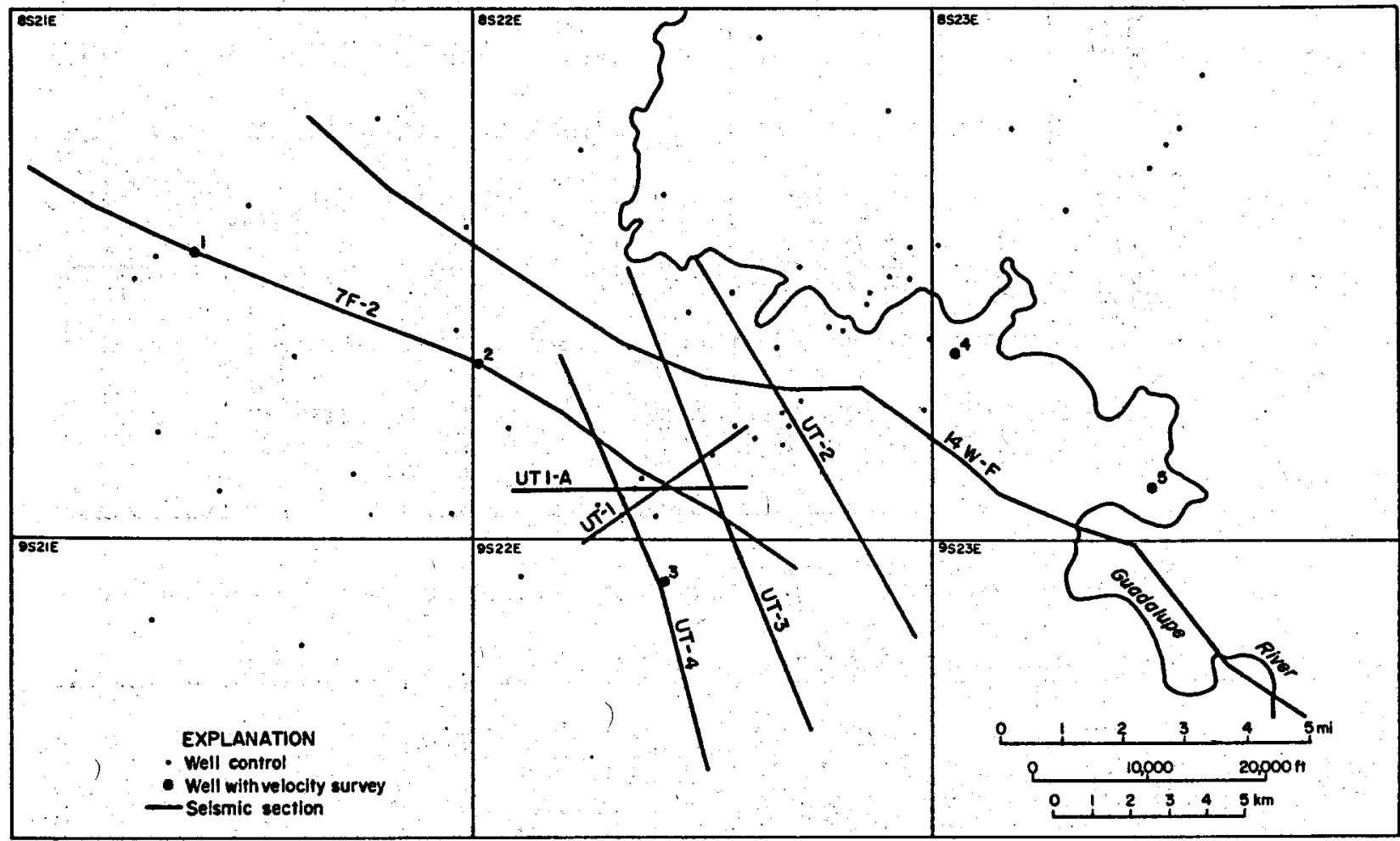

Figure 61. Base map of seismic data in Cuero study area. UT lines, acquired by Geosource, Inc., for this project, were laid out in true-dip orientation. 


\section{Proprietary Data}

The proprietary lines (figs. 62 and 63) are six-fold and were shot in the late 1960 's; the data are of good quality for lines of that age. The processing quality of the lines as delivered was reasonable for 10 years ago but is inadequate by modern standards. Therefore, standard production reprocessing was performed on these two lines (table 11). The major areas of difference between original and reprocessed displays, in order of processing steps, are (1) automatic residual statics (not a serious problem in this area), (2) slower automatic gain control, which significantly improved the useful amplitude information, (3) reworked stacking velocities, (4) migration, and (5) display of all sections at approximately the same horizontal scale. In this area, migration is especially necessary for a proper structural interpretation. However, migration in areas of oblique-dip orientation, poor signal-to-noise ratio, bad statics problems, or multiples may only cause further deterioration of the seismic image.

\section{New Data}

New data in the study area were obtained in order to compensate for inadequacies in the existing data. The major changes in specifications from previous data were (1) change of orientation from oblique to true dip, necessary for proper twodimensional migration; (2) increase of multiplicity from 6- to 24-fold to increase signal-to-noise ratio; (3) increase of maximum offset from 5,500 ft (Arco) and 8,250 ft (Teledyne) to $10,800 \mathrm{ft}$ to improve multiple suppression and to obtain more precise estimates of rms velocities at depth; (4) true-amplitude recording rather than recording with field AGC; and (5) use of a staggered-offset layout for shotholes (fig. 64).

The staggered-shothole configuration was designed to produce four closely spaced, 6-fold lines, which could be either processed separately to provide cross-dip control or stacked together to produce a single 24 -fold line. In practice, the desired configuration was impossible to achieve for several reasons. The offsets greatly 


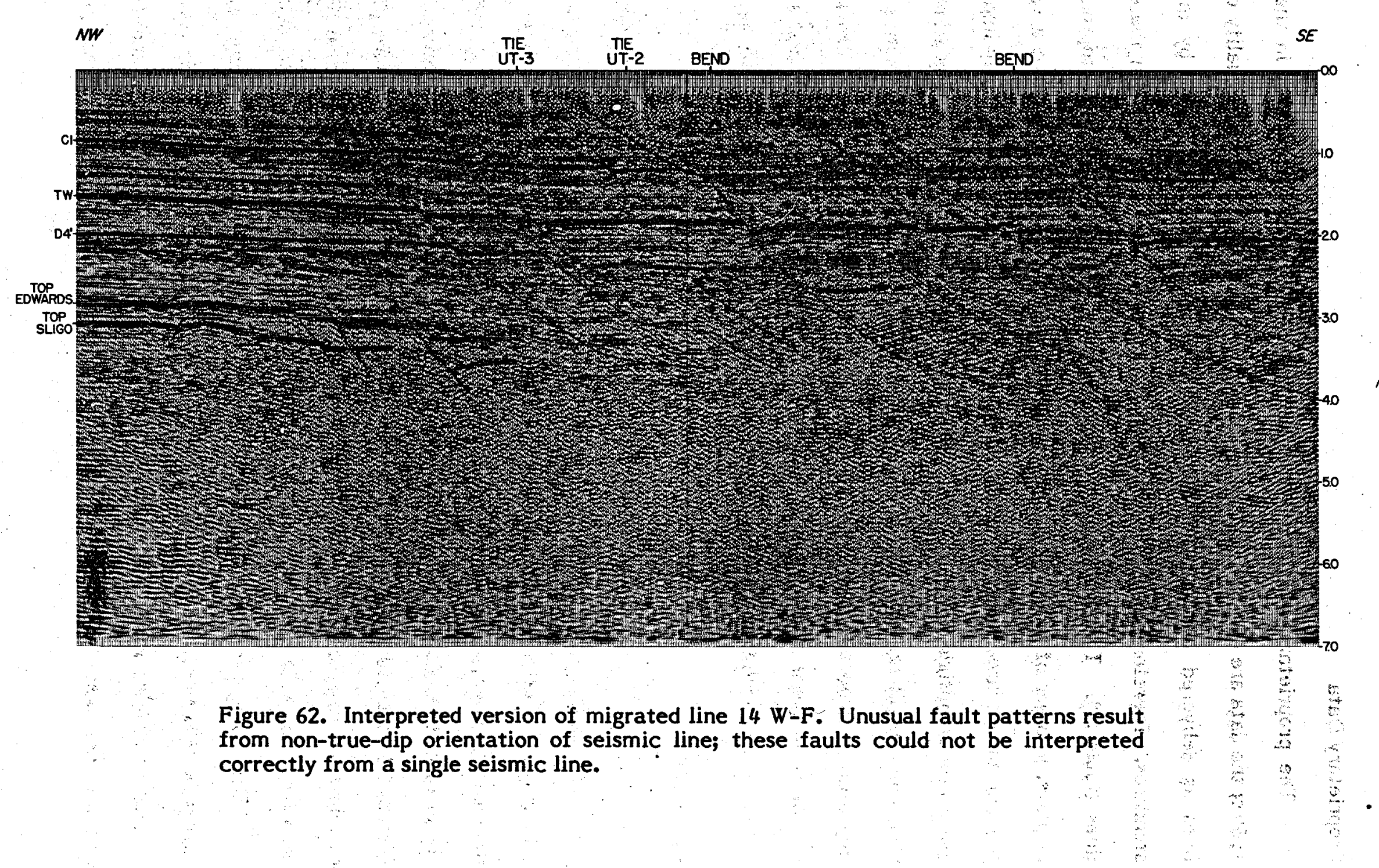




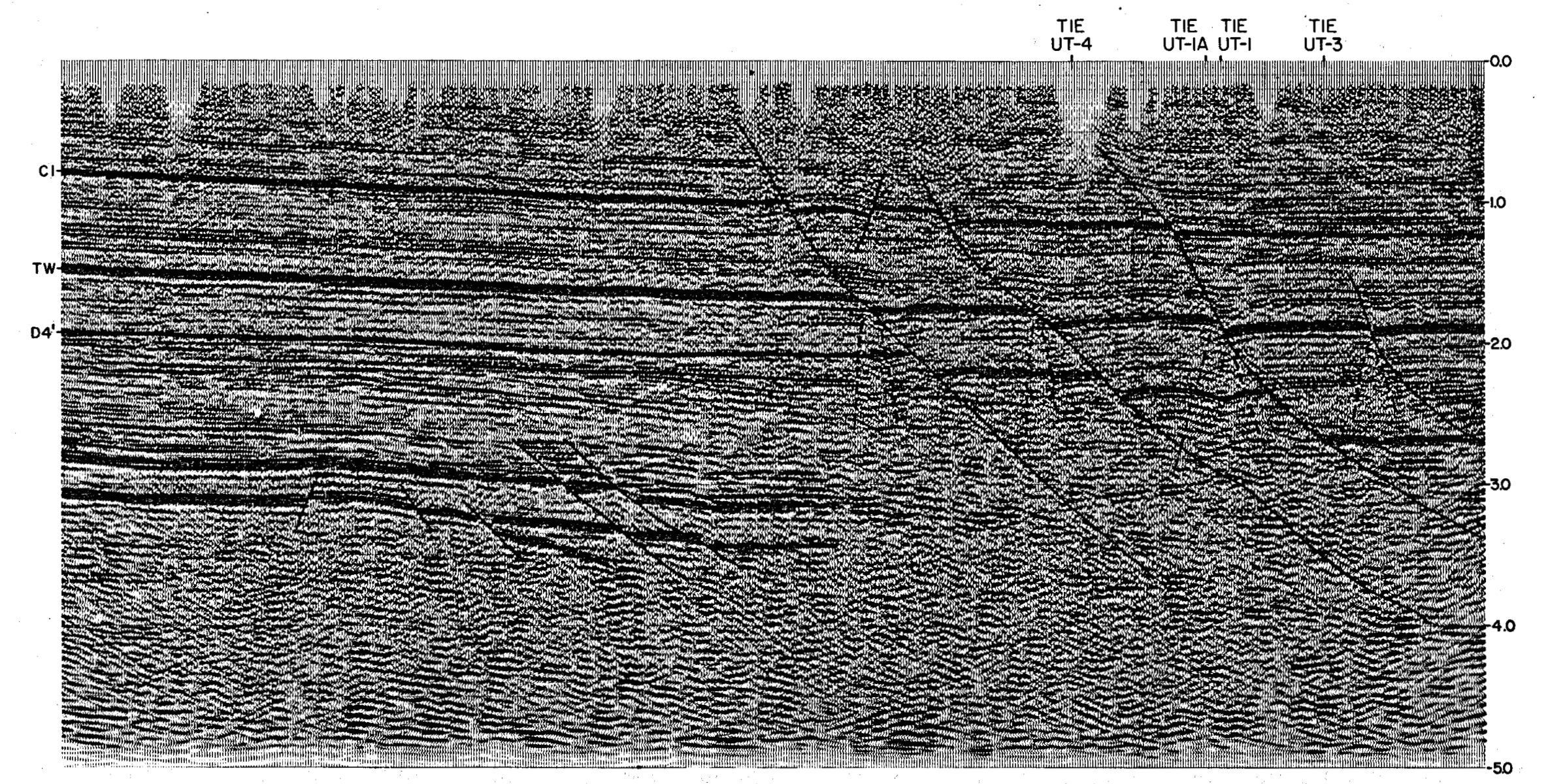

Figure 63. Interpreted version of migrated line 7F-2. Deep projection of faults is speculative; they are drawn to suggest décollement in deep non-diapiric salt. Note "wipe-out" zone of poor signal-to-noise ratio and apparent velocity pulldown under faults cutting top of Wilcox. 
A SP 0

0

o

○

0

$\circ$

0

0

o

0

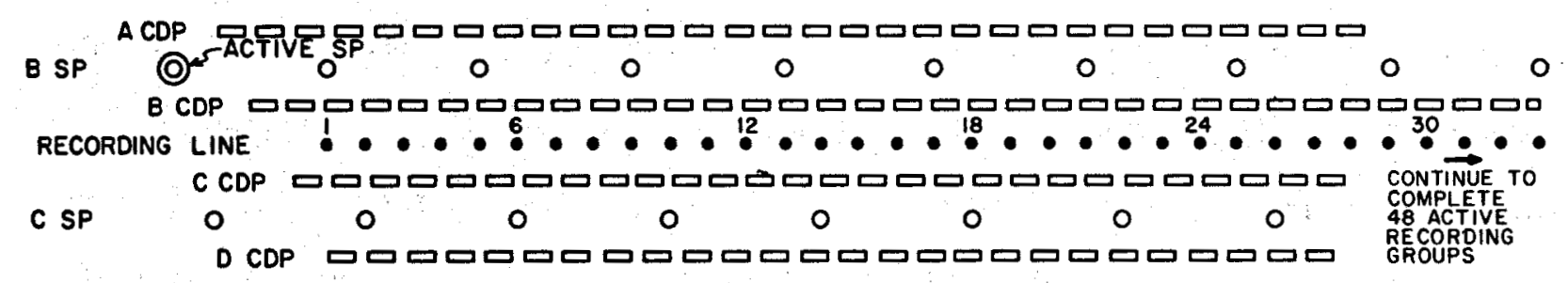

D SP

0

0

0

0

0

0

0

0

0

Figure 64. Originally proposed layout of shotpoints with staggered offsets to provide cross-dip control. From M. M. Backus (personal communication, 1979). Intention was to obtain four closely spaced parallel 6 -fold lines. 
increase the amount of land that needs to be permitted, and they more than double the total length of line that must be cleared for access by surveyors, drillers, and recording crews. In many cases, it was impossible to place the shotholes where specified. The resulting deviations were so severe that in no area was it possible to obtain four 6-fold lines of acceptable quality (fig. 65), although the combined 24-fold stacks are of good quality. It would be safe to conclude that such a shooting plan is impractical in areas similar to that of Cuero, which has numerous small land holdings, many buildings and structures, and dense brush.

To take full advantage of modern migration processing, we attempted to make use of fault-plane reflectors as a criterion for fault recognition. On the basis of preliminary structural interpretations from well logs and two proprietary lines, three sections were constructed, both in depth and in time with the fault planes in their predicted correct position (fig. 66). Then, these fault planes were graphically "demigrated" to their predicted position on un-migrated sections (fig. 67) by use of a raypath and wave-front chart derived from a velocity survey and Snell's law (fig. 68). This demonstrated that the fault-plane reflectors would be detected at depth points as much as $3 \mathrm{mi}$ downdip from the correct migrated position (fig. 68). For this reason, it was considered desirable to extend the coverage of dip lines substantially downdip of the fault block of interest, which required relatively long lines (fig. 61).

Permit problems further limited the coverage of the new seismic data. Nopermit areas, which precluded both geophones and shotholes, restricted the updip limit of line UT-4 and the western end of line UT-1. No-shot areas created serious gaps in full-fold coverage near the area of interest on UT-4 and on lines UT-1 and 1A, and necessitated the unusual configuration of the strike lines (fig. 61).

$14 W-F$

This line provides the best overview of the structural style of the prospect area, although it passes to the east of the primary area of interest and has an oblique-dip 


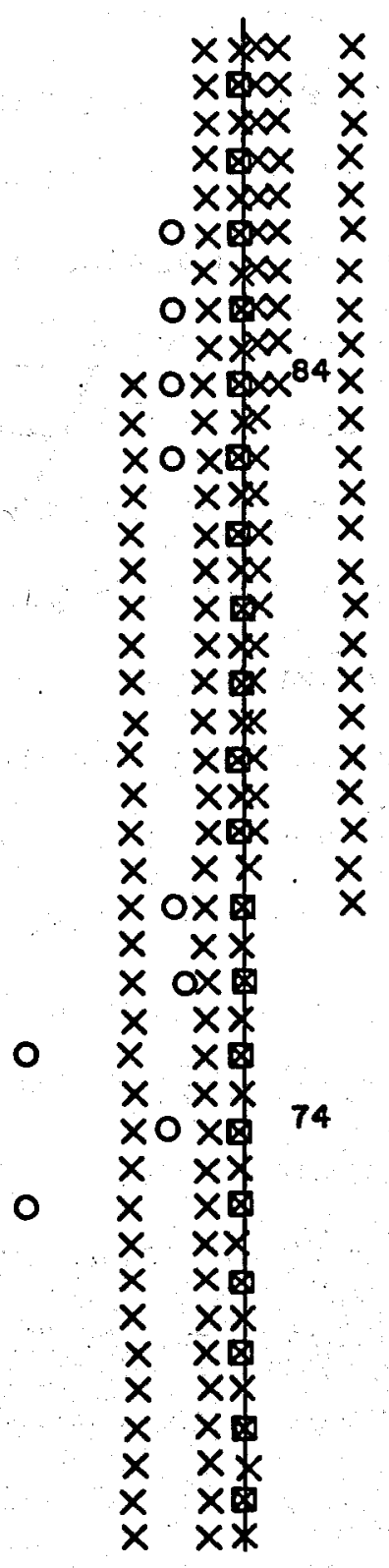

Figure 65. Map of shotholes, geophone stations, and shot-receiver midpoints for a segment of line UT-4. Deviations from proposed shothole layout result in low multiplicity for outboard sections. Shot locations are represented by circles. 


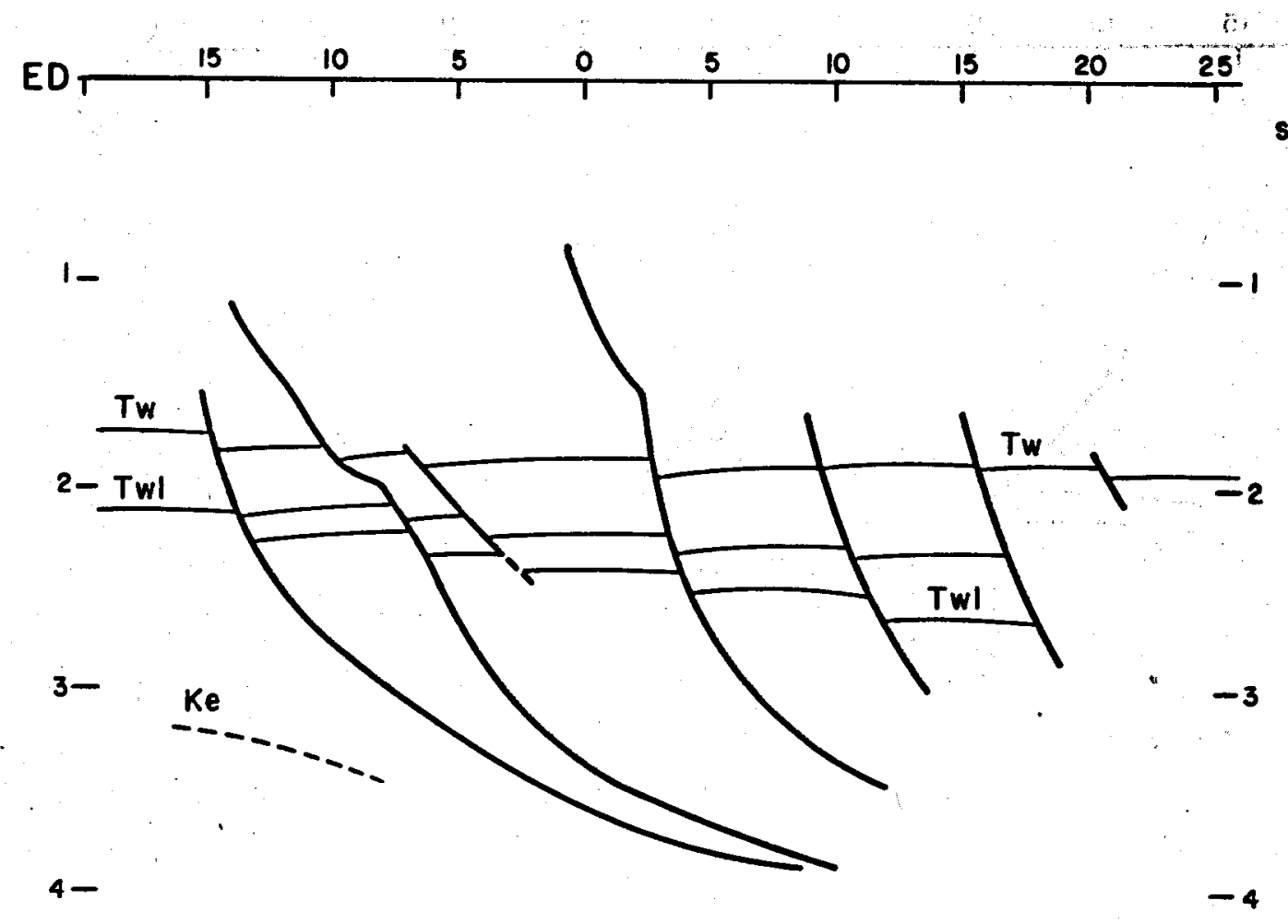

\section{$\underset{s e c}{\downarrow}$}
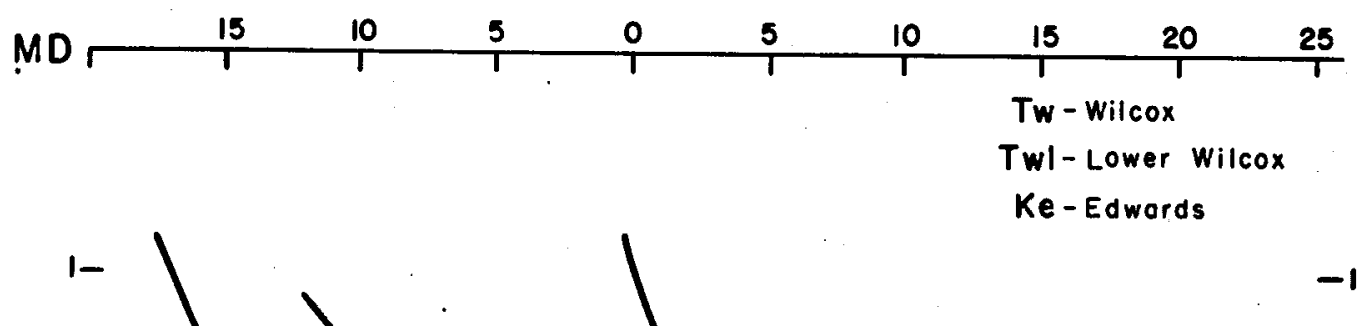

$-1$

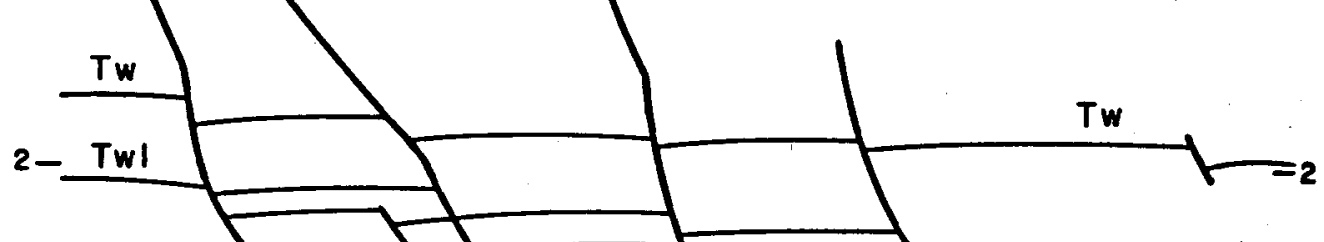

$3-\frac{K e}{}$

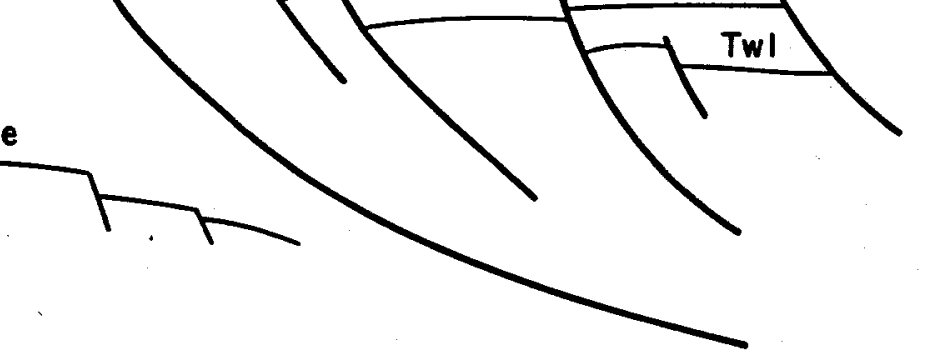

4-

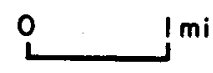

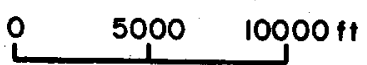

$-4$

Figure 66. Structural dip sections (vertical scale in travel time) constructed before acquisition of UT LW-3 or reprocessing of proprietary lines. These sections were designed to predict positions of unmigrated fault-plane reflectors (fig. 67). 


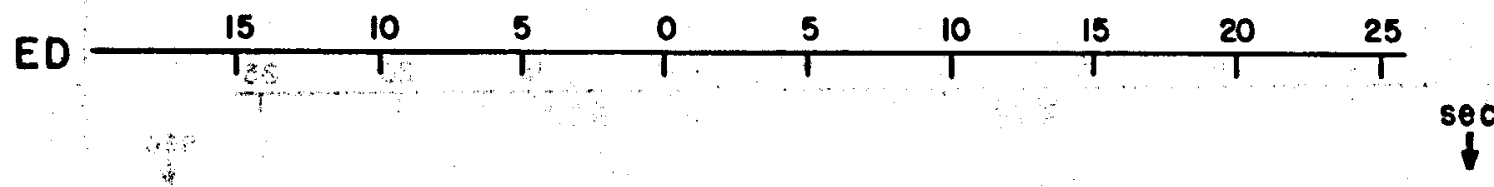

$1-$

$-1$
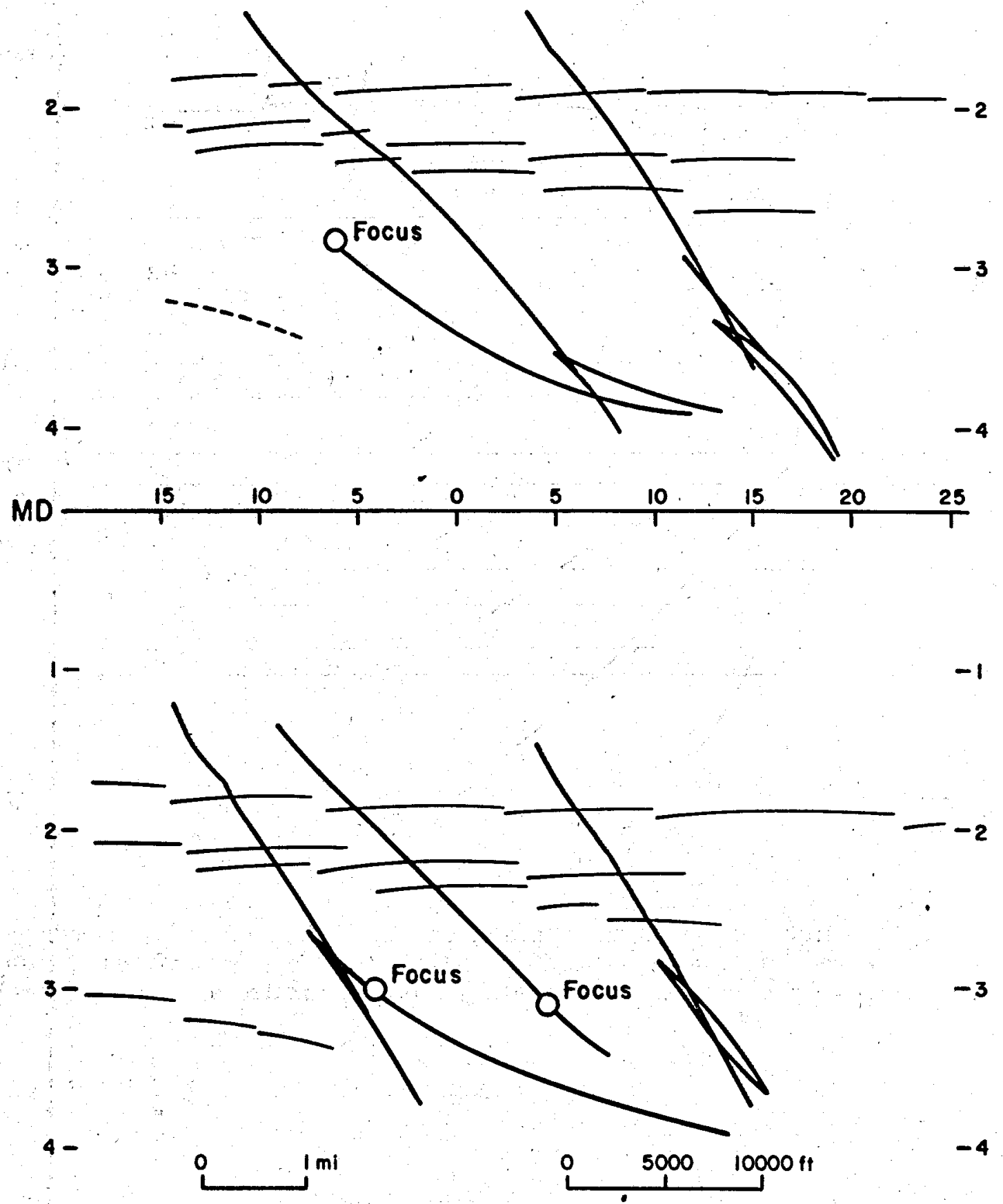

Figure 67. Structural dip sections from figure 66 with fault-plane reflectors moved to their predicted unmigrated positions using graphical methods. In order to record faultplane reflectors, lines must be extended downdip from area of interest. 


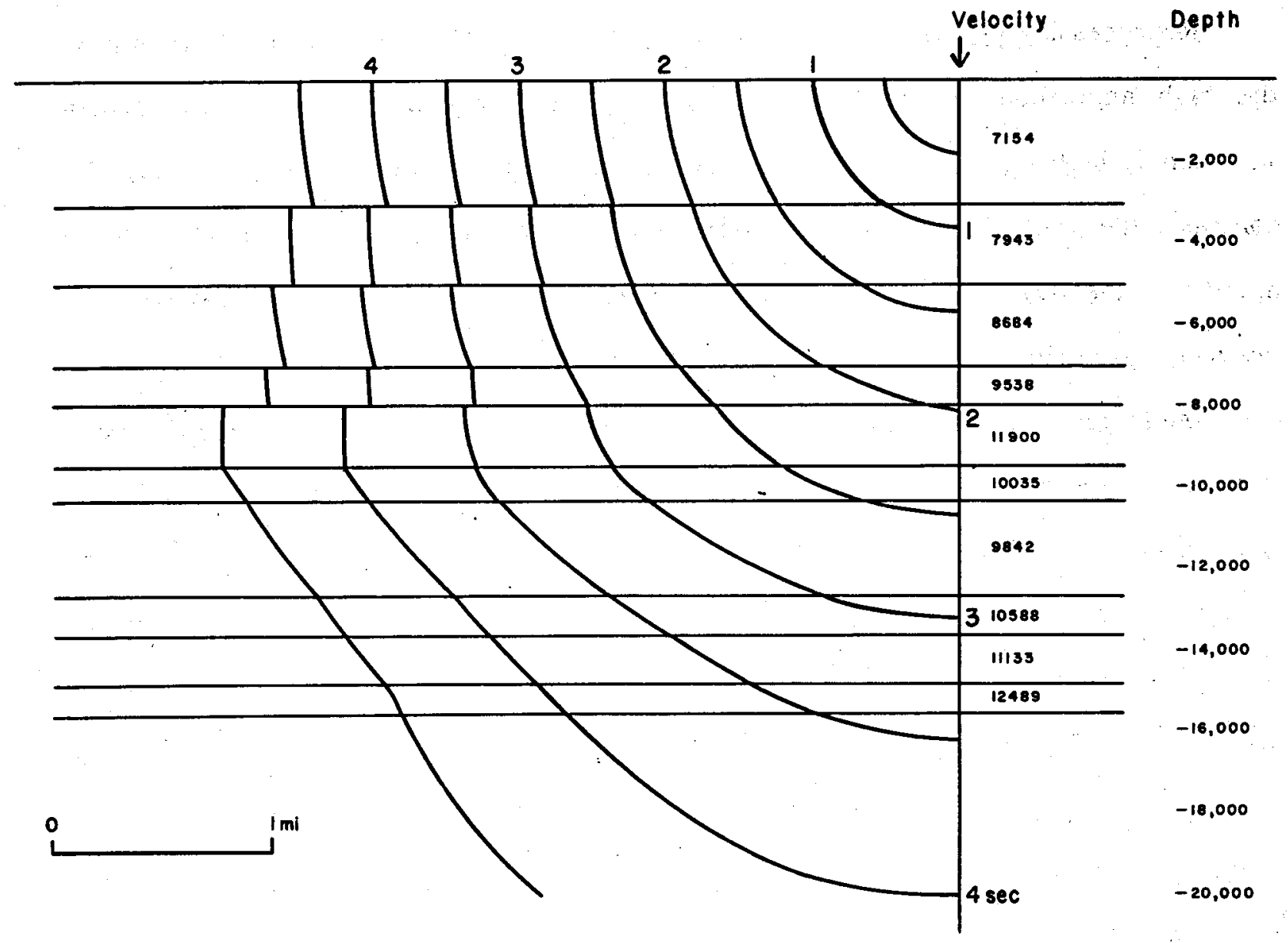

Figure 68. Wavefront and raypath diagram, constructed graphically according to Snell's law, based on interval velocities from velocity survey, Atlantic \#1 Hartman well. This diagram was used to "de-migrate" fault-plane reflectors from figures 66 to 67. 
orientation. The interpreted line (fig. 62) shows the Lower Cretaceous carbonate Stuart City and Sligo shelf edges, the progradation of the Paleocene Midway slope (clinoforms), the initiation of growth faulting as the Wilcox shelf edge prograded basinward from the Lower Cretaceous shelf-edge positions, and the continued movement of the faults in post-Wilcox time.

Reprocessing greatly improved the amplitude content of the display, emphasizing the high amplitude of the Stuart City, Sligo, and Wilcox tops. It also shows surprisingly high amplitudes in the all-shale Midway and lower Claiborne sections. In contrast, the updip Wilcox is characterized by low amplitude and continuity. Data quality in the downdip lower Wilcox, however, did not benefit from reprocessing as much as was anticipated.

Migration was of great benefit in picking faults for the final interpretation (fig. 62). In the post-Wilcox section in particular, migration increased the sharpness of bedding-plane terminations and discontinuities. Within the Wilcox section correct interpretation of faults was more ambiguous. The most confusing section occurs within the reservoir fault block because of the substantial departure from true-dip orientation. Faults appear to flatten with depth as the line departs farther from a true-dip orientation. These fault traces cannot be properly interpreted directly from a single line, either un-migrated or migrated. It was necessary first to interpret the other lines, then tie those lines to $14 \mathrm{~W}-\mathrm{F}$.

$7 F-2$

This line (fig. 63) is more useful than 14W-F from the standpoint of structural evaluation, in that it more nearly maintains a true-dip orientation through the fault block of interest. It shows basically the same structural features as $14 \mathrm{~W}-\mathrm{F}$, except that it does not extend as far downdip. In the section as delivered, the continuity of reflectors and general data quality, particularly in the growth-faulted area, are not as good as in $14 \mathrm{~W}-\mathrm{F}$. 
Much of this difference in data quality was eliminated by reprocessing. Reflector continuity was improved by application of automatic residual statics. Reworking of stacking and velocities contributed to improved data quality in the Wilcox fault zone.

As with $14 \mathrm{~W}-\mathrm{F}$, migration significantly improved the fault interpretation (fig. 63) with the added advantage that this line maintains a nearly constant orientation. However, fault picks were complicated by zones of greatly reduced signal-tonoise ratio beneath the faults cutting the top of Wilcox. These "wipe-out" zones appear on the migrated section to be velocity pull-downs, although their exact cause has not been determined. Ties with wells have demonstrated that these zones do not indicate discontinuities of bedding-plane reflectors representing the true fault positions, as was originally thought. Instead, they occur significantly below and updip of the fault trace. The velocity pull-down effect results in apparent structure on the top of lower Wilcox, which conflicts with that mapped from well control.

$\mathrm{UT}-4$

This dip section (fig. 69) ties the type well and the primary area of interest. The improved data quality over line $7 \mathrm{~F}-2$, which ties the same wells, can be attributed primarily to the increased multiplicity resulting in improved signal-to-noise ratio. Multiples are apparently not a serious problem in this area, as the increased spread on line UT-4 did not result in any significant multiple suppression when compared with 7F-2 (fig. 63).

Continuity of reflectors, frequency content, and clarity of faults is very good in the shallow part of the section, down to the top of Wilcox. Within the Wilcox section, reflector continuity and amplitude are not as good as was hoped, but they still represent an improvement over 7F-2. Large no-permit areas, particularly the one around the type well, significantly reduced in data quality because only far-offset 


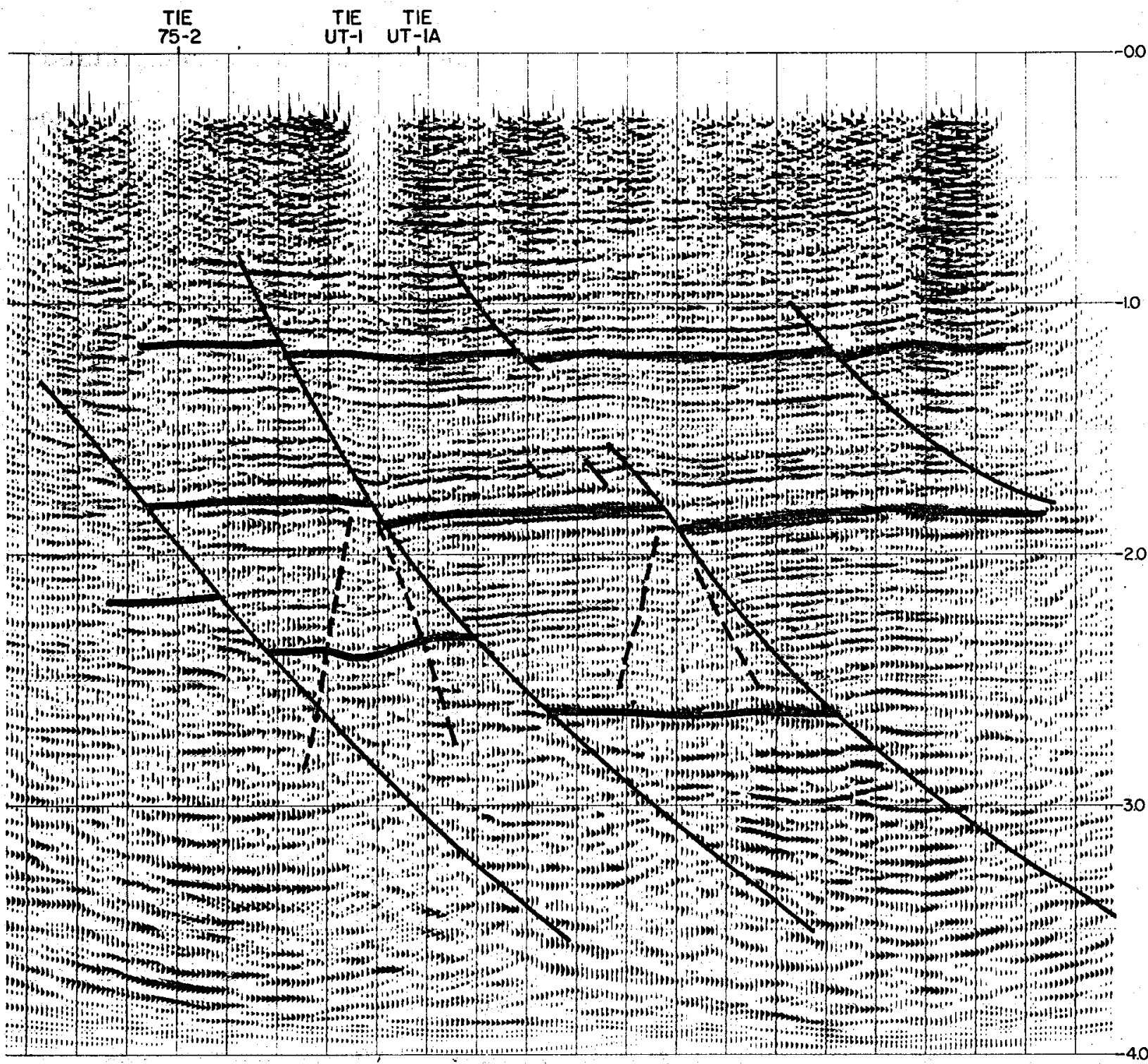

Figure 69. Migrated line UT-4 with interpretations. Note "wipe-out" zone similar to that in figure 63. 
traces could pe recorded r $_{j}$ This is particularly true in the shallow, parti of the section, because far-offsegt traces are contaminated with early ground roll, usually requiring muting.:

The most serious problem with interpreting the lower Wilcox on this section is the "wipe-out" of data quality below the major faults where ${ }_{i}$ they cut the topl of Wilcox. The consistency of this phenomenon among all the UT dip lines and $7 \mathrm{~F}-2$ suggests that it is inherent in the geometry and velocity structure of the area and is not attributable to incorrect shooting parameters or improper data processing. As with $7 F-2$, migration results in apparent troughs in the structure on the top of lower Wilcox under the growth faults (fig. 69); these apparent troughs are contradicted by closely spaced well control.

Fault-plane reflectors show up better on UT-4 than on 7F-2 or $14 \mathrm{~W}-\mathrm{F}$, perhaps because of the increased multiplicity and resultant improvement in signal-to-noise ratio. As predicted (fig. 67), the unmigrated reflectors appear far downdip of their correct position, justifying the downdip extent of coverage. Migration unfortunately does not preserve the full amplitude of fault-plane reflectors, which tends to reduce their usefulness. Upward concavity of fault-plane reflectors at depth may be an artifact of migration. The migration algorithm "smears" noise along estimated wavefronts; often these crescentic features appear to be continuous with shallower fault-plane reflectors. As mentioned earlier, the small amount of rollover at depth suggests that the faults probably become listric beneath the Cretaceous section.

A further attempt was made to utilize fault-plane reflectors by restacking the section at the optimum velocity for these steeply dipping events. Theoretically, the optimum stacking velocity of a reflector of dip $\delta$ is:

$$
\mathrm{C}_{\mathrm{rms}} / \cos \delta
$$

(M. M. Backus, personal communication, 1980). Because most of these faults dip approximately $45^{\circ}$, the original stacking velocities were multiplied by a factor of 1.4 . 
The result of this high-velocity stack was enhancement of fault-plane reflectors and suppression of bedding-plane reflectors (fig. 70). Migration of the enhanced faultplane reflectors should be performed at the true rms velocity rather than at the enhanced velocity. Unfortunately, the contractor used the higher velocity, with the result that the fault planes were migrated too far and lost much of their coherence. The error was not discovered until after the completion of the contract.

\section{UT -2 and UT -3}

Most of the remarks on line UT -4 are equally applicable to dip lines UT -2 and UT-3 (figs. 71 and 72). The main differences among the lines are in the gains applied to the final displays. All these sections show the same "wipe-out" zone on the unmigrated sections and apparent velocity pull-down on the migrated sections. Highvelocity stacks were also performed on UT -2 and UT -3 , with similar results:

\section{UT -1 and UT - $1 \mathrm{~A}$}

Originally, it was planned to shoot a single strike line within the fault block of interest to tie the three dip lines. However, permit problems prevented tying with UT -2 and required putting a substantial dogleg between UT -3 and UT-4, causing it to be shot as two separate lines (fig. 61). Permit problems also prevented the use of the staggered-offset shothole configuration.

The main problem encountered with the strike line, however, was that it lies entirely within the "wipe-out" zone; consequently, the section is virtually uninterpretable (fig. 73). Even without this phenomenon, as a general rule strike sections are adversely affected by diffractions off faults which, unlike dip lines, cannot be eliminated by migration. It can be concluded that strike lines are commonly not worth shooting if the zone of interest lies directly underneath a nearby fault or if the faults are closely spaced. 


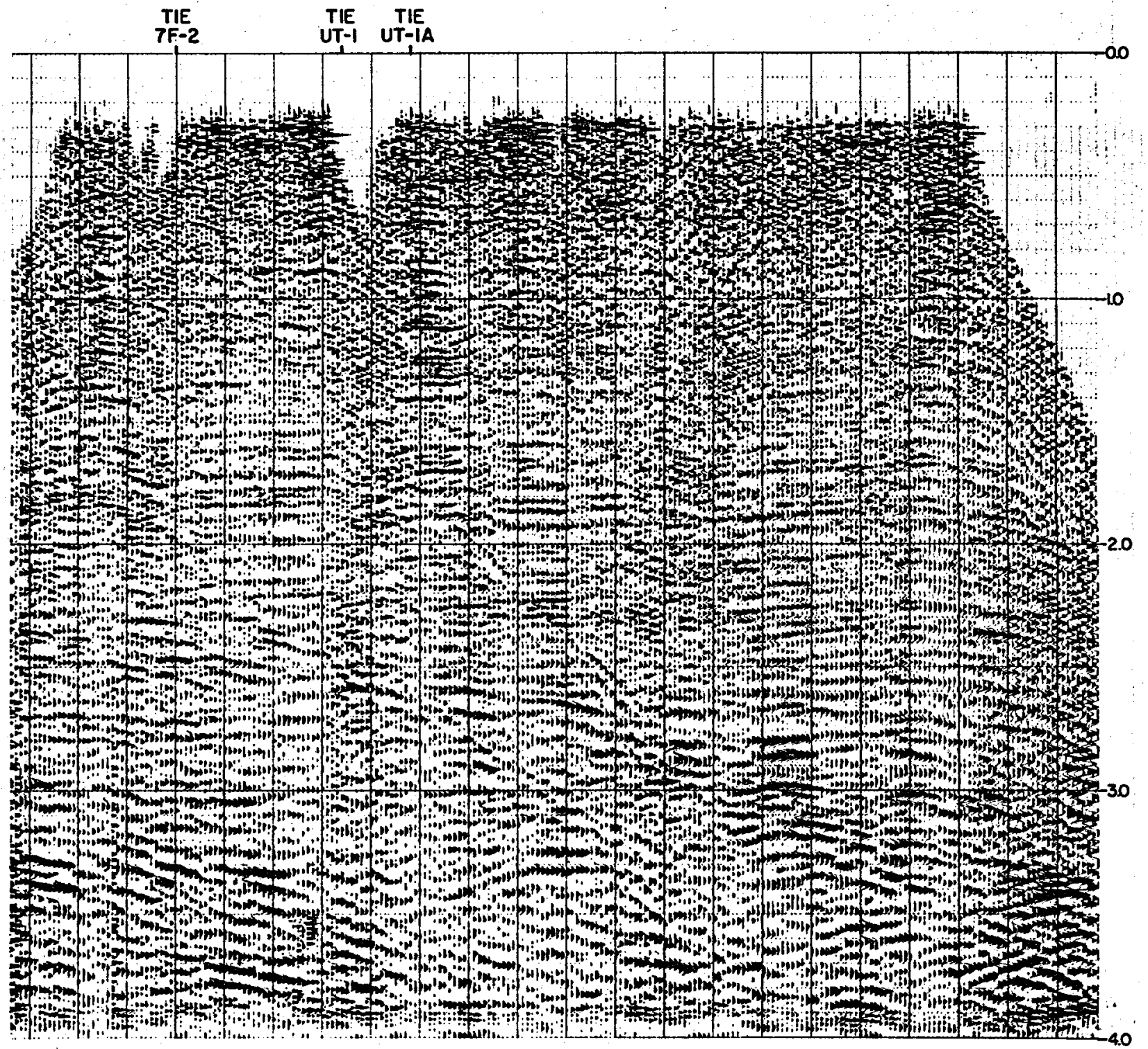

Figure 70. Line UT -4 restacked with velocities approximately 1.4 times optimum stacking velocities, designed to enhance fault-plane reflectors over bedding-plane reflectors. Results were moderately successful on this line and UT-3, less successful on UT-2. 


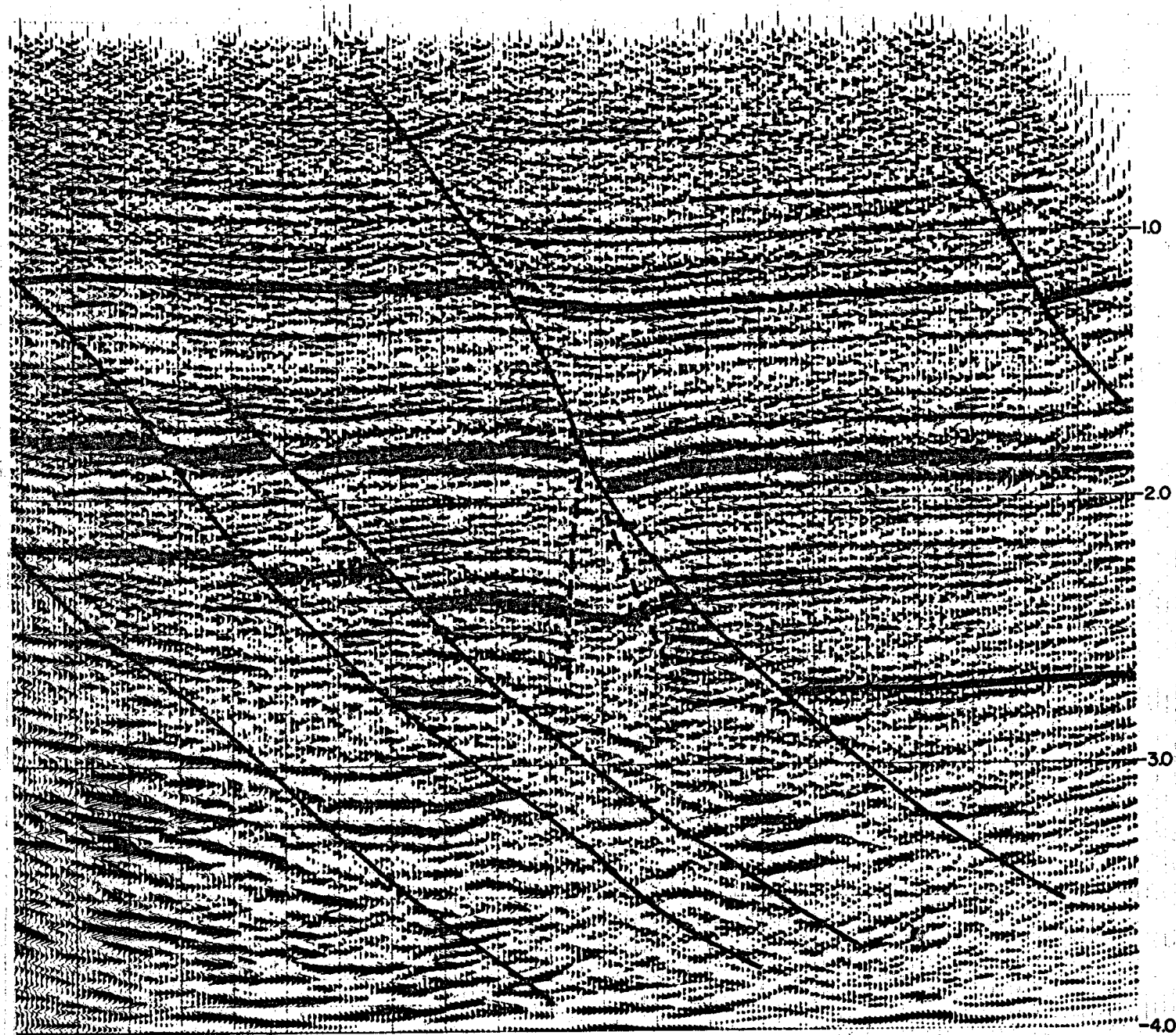

Figure 71, Migrated line UT -2, with interpretations. Again, "wipe-out" zones show up under faults cutting top of Wilcox. Correct interpretation of faults requires well control, especially when faults are closely spaced. 


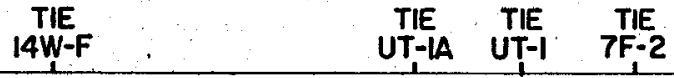

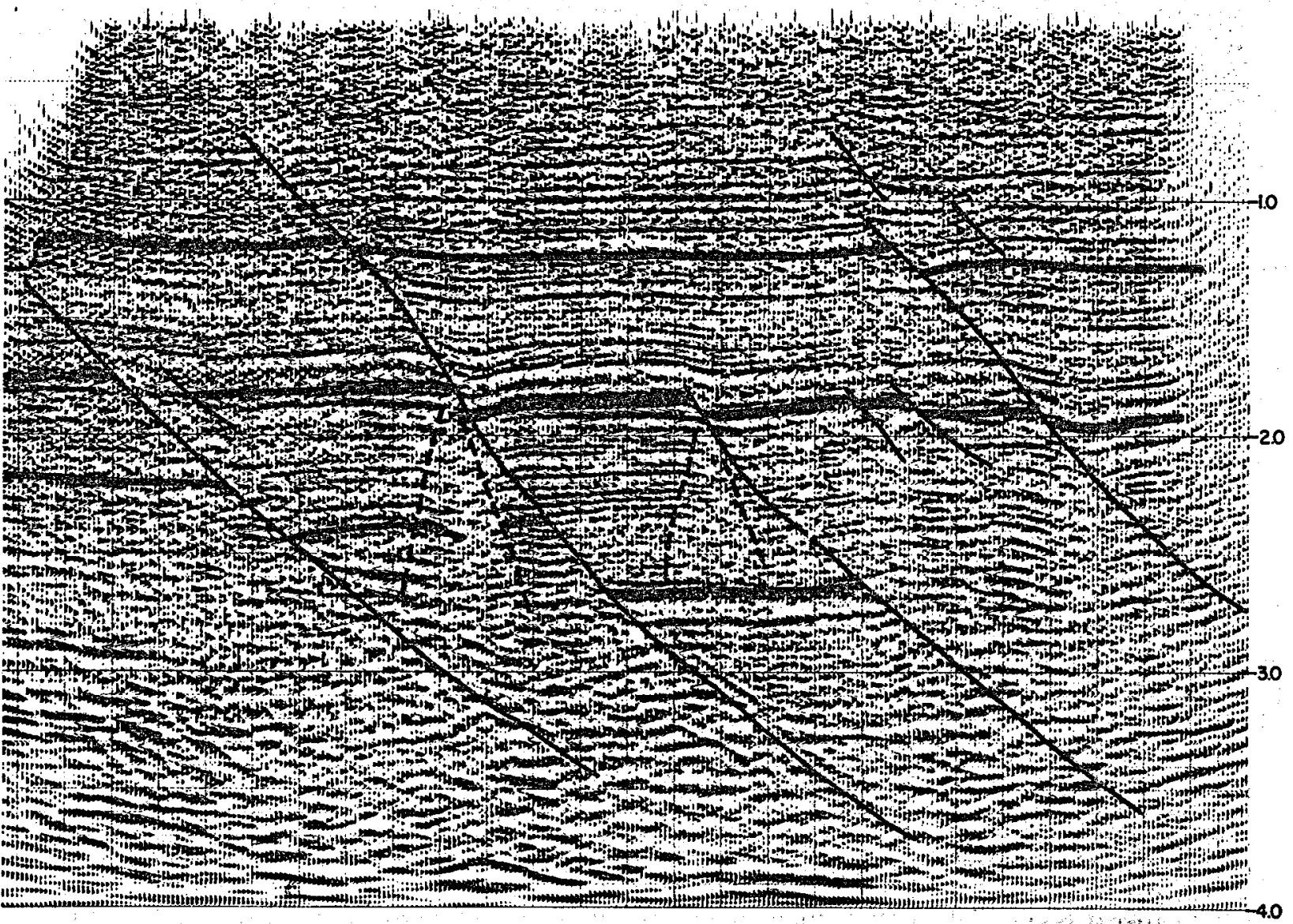

Figure 72. Migrated line UT-3, with interpretations, "Wipe-out" zone is consistent with other lines. 


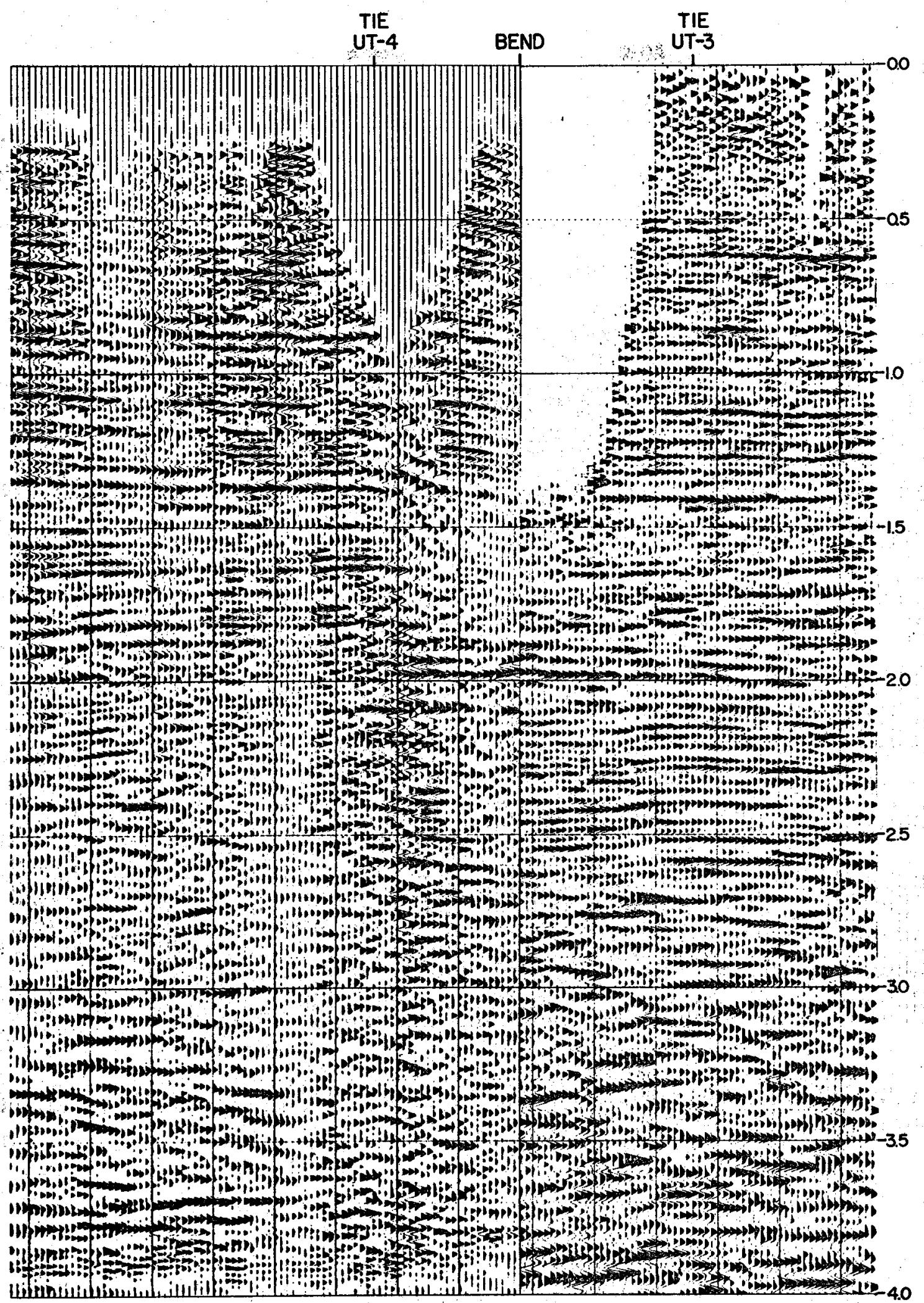

Figure 73. Composite strike section UT-1 and UT-1A. Entire line is within "wipe-out" zone, accounting for poor quality of deep data. 
Velocity Distribution

Interval Velocities

To a first approximation, interval velocities in the Cuero area (fig. 74) are a function of stratigraphy (table 9). The most notable aspect of interval velocities in this area is a large discontinuity at the top of Wilcox, resulting in a high-amplitude reflector. Major velocity inversions are created by (1) a transition from Wilcox sandstone to Midway shale (updip area); (2) a transition from a more sandy upper Wilcox to a more shaly middle Wilcox; and (3) a low-velocity lower Wilcox downdip of these. Only the last inversion can probably be attributed to a transition from normal pressure (normal consolidation of shale) to overpressure (underconsolidation of shale). Consequently, it would be unreasonable in this area to map the top of geopressure from the first major velocity inversion.

Stacking and rms Velocities

Velocity-survey data were used to bracket the range of rms-velocities in the study area (fig. 75) and to compare these with stacking velocities obtained from velocity analyses from the UT lines. From these comparisons the following observations can be made. (1) Stacking velocities generally fall within the range of rms velocities. However, some stacking velocities fall above the range, for unknown reasons. In addition, the range of uncertainty caused by interpreter subjectivity may be greater than the rms range. (2) The skilled interpreter can usually pick the inflections in the rms curve, and therefore pick major breaks in interval velocity. (3) Stacking velocities do not show the systematic downdip decrease that is seen in rms velocities.

\section{Time-Depth Conversion}

Time-depth conversion derived from integrated acoustic logs and from velocity analyses were compared with those obtained from velocity in two nearby well surveys 


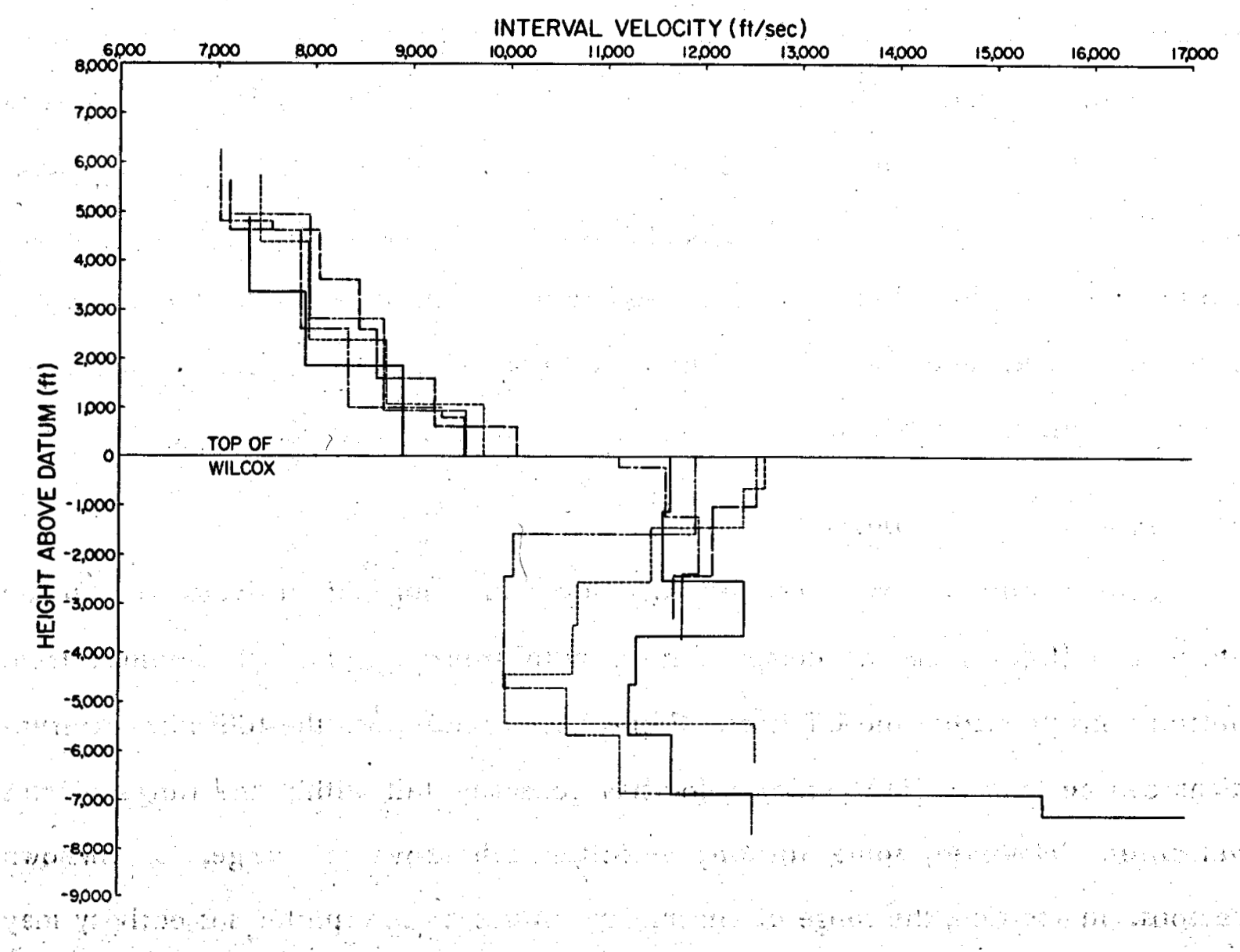

Figure 74. Interval velocities based on velocity surveys from five wells (fig. 61) which are widely enough distributed to bracket velocities in the study area. Note large velocity discontinuity at top of Wilcox.

1...?in

ans $: 3$

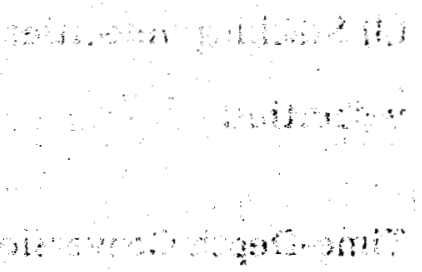




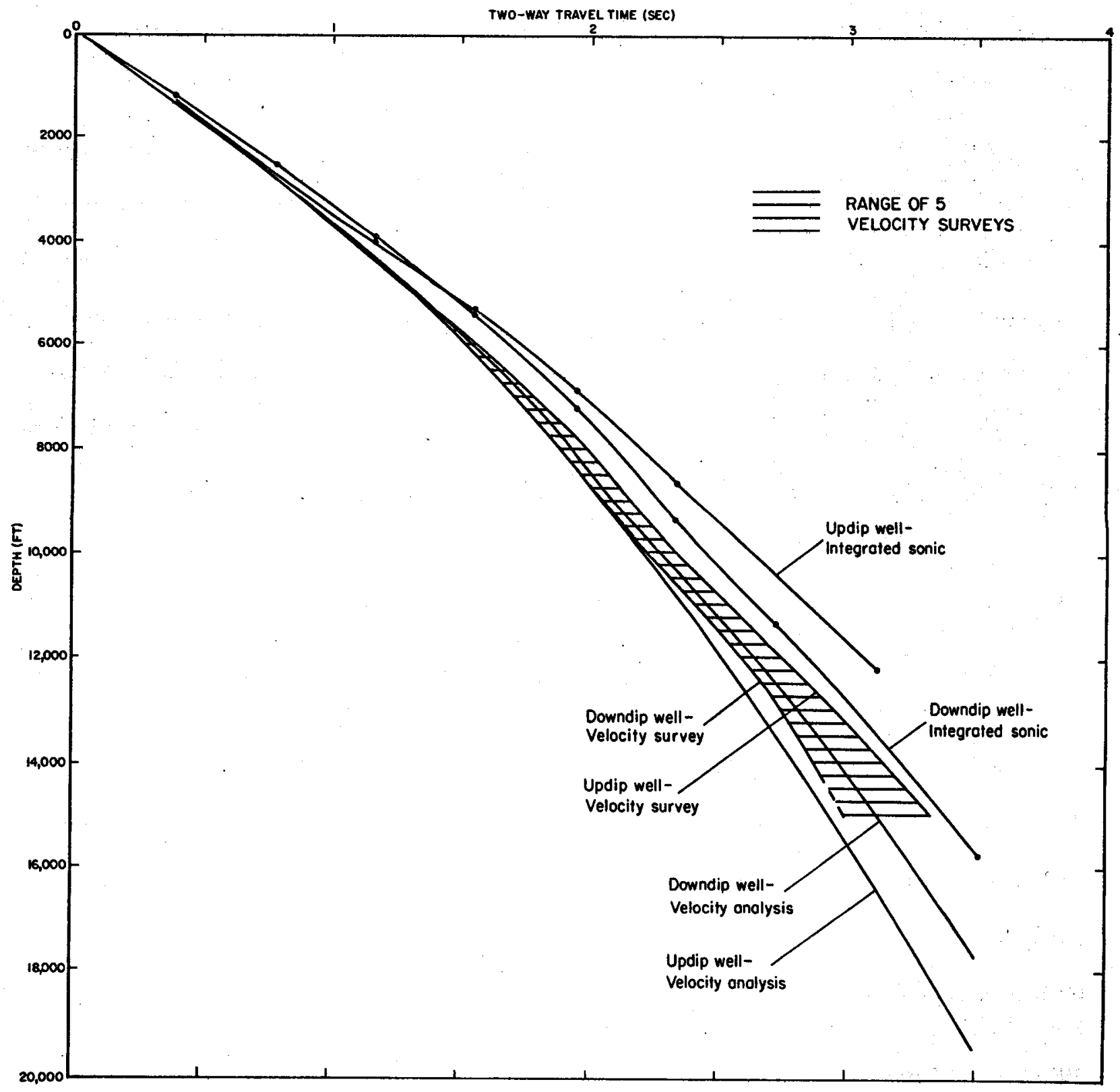

Figure 75. Range of rms velocity curves derived from interval velocities in figure 74 , compared with stacking velocities picked from Velscans (trial stacks with a range of stacking-velocity functions) and contour plots of velocity analyses. 
that were assumed to be the most accurate (fig. 76). Integrated acoustic logs systematically overestimate the travel time by underestimating velocities. The magnitude of this error is difficult to predict, but depends on the quality of the acoustic $\log$ and on the amount of prior editing for obvious cycle skips. Neither $\log$ used in figure 76 was edited before integration.

Velocity analyses tend to give fairly good time-depth estimates at shallow depths but deteriorate as depth increases. This is a result of both decrease of maximumoffset-to-depth ratio, causing a decrease of normal moveout, and decrease of amplitude and signal-to-noise ratio of reflectors. Interpreters tend to pick stacking velocities on the high side to avoid stacking of multiples. Therefore, interval velocities are generally overestimated from velocity analyses, and travel times are underestimated, in contrast with estimates from integrated acoustic logs.

Conversion to true depth and removal of vertical exaggeration is easy to perform digitally with seismic data and is valuable for structural interpretation. The major problem is proper handling of lateral velocity variations caused by stratigraphically controlled velocity variations in structurally complex areas. If velocity increases steadily with depth, this will not be a major problem. However, large velocity discontinuities in this area make proper depth conversion difficult to achieve. Lateral velocity variations caused by variations in facies, diagenesis, and consolidation state (related to geopressure) are potentially a problem as well, but are more easily handled by lateral linear interpolation.

\section{"Wipe-Out" Zones}

The data quality in the area of greatest interest is poor and deserves further study. Because the "wipe-out" zones occur just below the faults cutting the top of Wilcox, we suspect that the velocity discontinuity at the top of Wilcox is one cause.

Common-depth-point (CDP) traces at different offsets represent different ray paths 

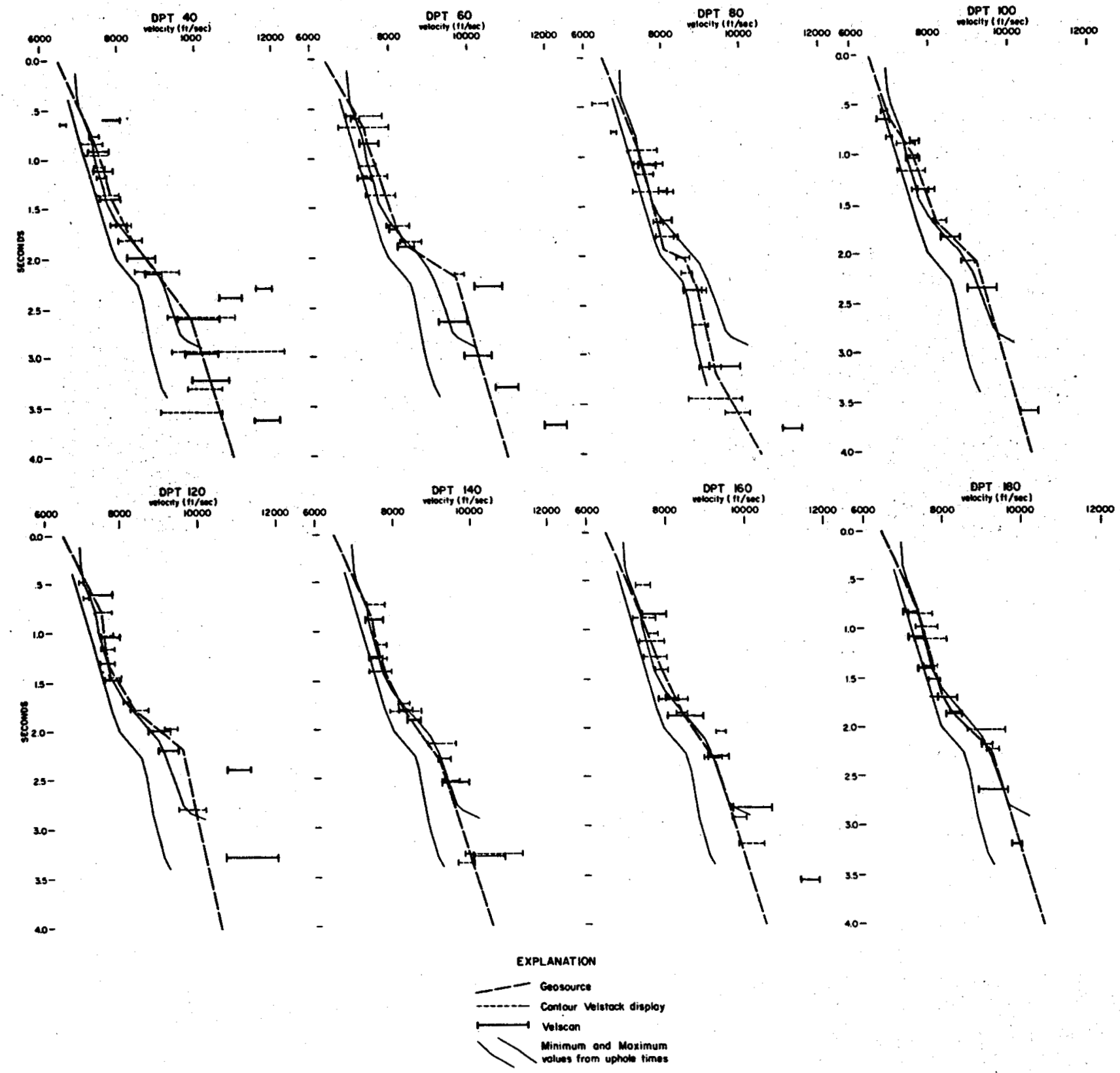

Figure 76. Time-depth conversions for the Cuero area based on different sources of data. Integrated logs tend to underestimate velocities and overestimate travel times, but to an extent that is difficult to predict. Velocity analyses tend to overestimate deep velocities and underestimate travel times, particularly where velocity inversions occur. 
through the top of Wilcox to reach lower reflectors. A large velocity discontinuity on a non-flat surface could cause significant static shifts from one CDP trace to the next. This hypothesis could be tested by applying an automatic residual static shift to that portion of the data below the top of Wilcox.

\section{COMPARISON OF AREAS}

Among the three areas in Texas chosen for intensive site-specific evaluation, the most striking differences are in structural style (fig. 5) and sandstone distribution (fig. 16). Structure in the Pleasant Bayou area is the result of two independent structural mechanisms and styles superimposed to produce a complex structure of high relief. Growth faulting and salt mobilization operated in concert to produce the Chocolate Bayou anticline, Danbury Dome, and the intervening salt-withdrawal basin. Structural relief is also high in the Blessing area, but it resulted from a relatively simple sequence of growth faults with large rollover and counter-regional dip. Structural highs on the upthrown side of major growth faults may be due partly to shale masses beneath the fault planes. In contrast to the high-relief structure in the two areas along the Frio trend (Pleasant Bayou and Blessing), the Cuero area is characterized by low-relief, virtually flat structure, with very little rollover. In plan, the Wilcox faults at Cuero are subparallel, of low sinuosity, and fairly uniformly spaced (1-2 mi), as opposed to the sinuous, arcuate faults and the wide range of fault spacing in the Frio areas.

The two Frio fault blocks are not only larger than the Wilcox fault block, but the relationship of optimum reservoir facies to fault block morphology is better suited for water production in the Pleasant Bayou and Blessing areas than in the Cuero area (fig. 16). In the Pleasant Bayou area the thickest sandstones with blocky SP patterns

occur in an area that is nearly equidimensional and that comprises about $25 \mathrm{mi}^{2}$ of the 
large fault block. At Blessing the axes of optimum sand distribution parallel the strike of the fault block and are centrally located within it. These arrangements provide a wide radius, free of permeability boundaries. In contrast, the optimum reservoir facies of the Cuero area are much more limited in areal extent than those of the Frio sandstones (fig. 16). This results from the relatively narrow, dip-oriented sandstone trends perpendicular to the long axis of the fault block. This not only limits the potential reservoir volume but severely constrains possible test-well location in distributary channels.

In spite of the higher geothermal gradient of the Wilcox as a whole (Bebout and others, in press), potential geothermal aquifers in the Cuero area have lower temperatures than those in the Pleasant Bayou area because of shallower depths, but aquifer temperatures are slightly higher than temperatures in the Blessing area (table 4). The Cuero and Blessing areas have similar pressures, but these are substantially lower than in the deeper Pleasant Bayou area (table 4). In general, the stratigraphic and structural relationships that result in geopressure are similar in all three areas. Geopressured sandstone reservoirs are limited on the updip side by downfaulting against shelf-slope shales and on the downdip side by upfaulting against transgressive shales (Anahuac and middle Wilcox). They are overlain by thick sequences of marine shale (fig. 5).

\section{ACKNOWLEDGMENTS}

This work was made possible through funding by the U.S. Department of Energy, Division of Geothermal Energy, under Contracts DE-AS05-76ET28461 and DE-AC0879ET27111. Geological maps and interpretations in the Blessing area were initially prepared by Scott Hamlin and Bonnie Weise as part of a study for the Gas Research Institute. Seismic studies greatly benefited from discussions with Milo M. Backus, who 
designed the shooting plan for the Cuero area and provided advice on data processing and interpretation. We are particularly grateful to personnel at the Bureau of Economic Geology who assisted in preparing this report. The manuscript was typed by Charlotte J. Frere under the direction of Lucille C. Harrell; illustrations were drafted under the direction of Dan F. Scranton. 


\section{REFERENCES}

Bebout, D. G., Loucks, R. G., and Gregory, A. R., 1978, Frio sandstone reservoirs in the deep subsurface along the Texas Gulf coast: their potential for production of geopressured geothermal energy: The University of Texas at Austin, Bureau of Economic Geology Report of Investigations No. 91, 92 p.

Bebout, D. G., Weise, B. R., Gregory, A. R., and Edwards, M. B., in press, Wilcox reservoirs in the deep subsurface along the Texas Gulf coast: their potential for production of geopressured geothermal energy: The University of Texas at Austin, Bureau of Economic Geology, Report of Investigations.

Bruce, C. H., 1973, Pressured shale and related sediment deformation: mechanism for development of regional contemporaneous faults: Amer. Assoc. Petrol. Geol. Bull., v. 57, p. 878-886.

Crans, W., Mandl, G., and Haremboure, J., 1980, On the theory of growth faulting: a geomechanical delta model based on gravity sliding: Jour. Petroleum Geol., v. 2, p. 265-307.

Dickinson, G., 1953, Geological aspects of abnormal reservoir pressures in Gulf Coast Louisiana: Amer. Assoc. Petrol. Geol. Bull., v. 37, p. 410-432.

Fisher, W. L., and McGowen, J. H., 1967, Depositional systems in the Wilcox Group of Texas and their relationship to occurrence of oil and gas: Trans. Gulf Coast Assoc. Geol. Soc., v. 17, p. 105-125.

Flanigan, T. E., 1980, Pore fluid pressure regimes, Brazoria County, Texas: a preliminary study: The University of Texas at Austin, Master's thesis, 118 p.

Fowler, W. A., 1970, Pressures, hydrocarbon accumulation, and salinities--Chocolate Bayou field, Brazoria County, Texas: Jour. Petrol. Tech., v. 22, p. 411-423. 
Galloway, W. E., Hobday, D. K., and Magara, K., in press, Frio Formation of the Texas Gulf Coast Basin--depositional systems, structural framework, and hydrocarbon origin, migration, distribution, and exploration potential: The University of Texas at Austin, Bureau of Economic Geology, Report of Investigations.

Lehner, P., 1969, Salt tectonics and Pleistocene stratigraphy on continental slope of northern Gulf of Mexico: Amer. Assoc. Petrol. Geol. Bull., v. 53, p. 2431-2479.

Loucks, R. G., Dodge, M. M., and Galloway, W. E., 1979, Sandstone consolidation analysis to delineate areas of high-quality reservoirs suitable for production of geopressured geothermal energy along the Texas Gulf Coast: The University of Texas at Austin, Bureau of Economic Geology, Report to the Dept. of Energy, Division of Geothermal Energy, Contract No. EG-77-5-05-5554, 98 p.

Milliken, K. L., Land, L. S., and Loucks, R. G., 1981, History of burial diagenesis determined from isotopic geochemistry, Frio Formation, Brazoria County, Texas: Amer. Assoc. Petrol. Geol. Bull., v. 65, p. 1397-1413.

Murray, G. E., 1955, Midway Stage, Sabine Stage, and Wilcox Group: Amer. Assoc. Petrol. Geol. Bull., v. 39, p. 671-696.

Storm, L. W., 1945, Resumé of fact and opinions on sedimentation in Gulf Coast region of Texas and Louisiana: Amer. Assoc. Petrol. Geol. Bull., v. 29, p. 1304-1335.

Todd, T. W., and Folk, R. L., 1957, Basal Claiborne of Texas, record of Appalachian tectonism during Eocene: Amer. Assoc. Petrol. Geol. Bull., v. 41, p. 2545-2566.

Toulmin, L. D., 1955, Cenozoic geology of southeastern Alabama, Florida, and Georgia: Amer. Assoc. Petrol. Geol. Bull., v. 39, p. 207-235.

Weise, B. R., Edwards, M. B., Gregory, A. R., Hamlin, H. S., Jirik, L. A., and Morton, R. A., 1981, Geologic studies of geopressured and hydropressured zones in Texas: test-well site selection: The University of Texas at Austin, Bureau of Economic Geology, Report to the Gas Research Institute, Contract No. 5011-321-0125, 308 p. 
Winker, C. D., and Edwards, M. B., in press, Unstable progradational clastic shelf margins, in Moore, G. T., and Stanley, D. O. (eds.), The shelf-slope boundary--a critical interface on continental margins: Amer. Assoc. Petrol. Geologists. 